\title{
PRZEMYSŁAW HENSEL
}

\section{Systematyczny przegląd literatury w naukach o zarządzaniu i jakości}

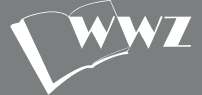

Wydawnictwo Naukowe Wydziału Zarzadzania Uniwersytetu Warszawskiego

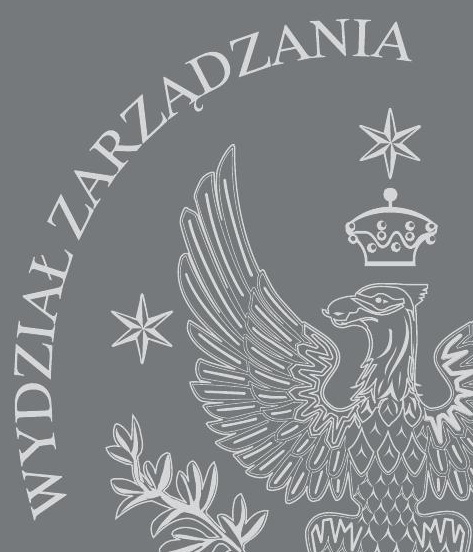





\section{Przemysław Hensel}

\section{Systematyczny przegląd literatury w naukach o zarządzaniu i jakości}

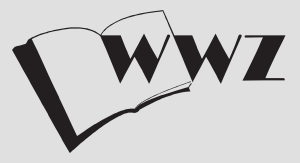

Wydawnictwo Naukowe Wydziału Zarzadzania Uniwersytetu Warszawskiego
Warszawa 2020

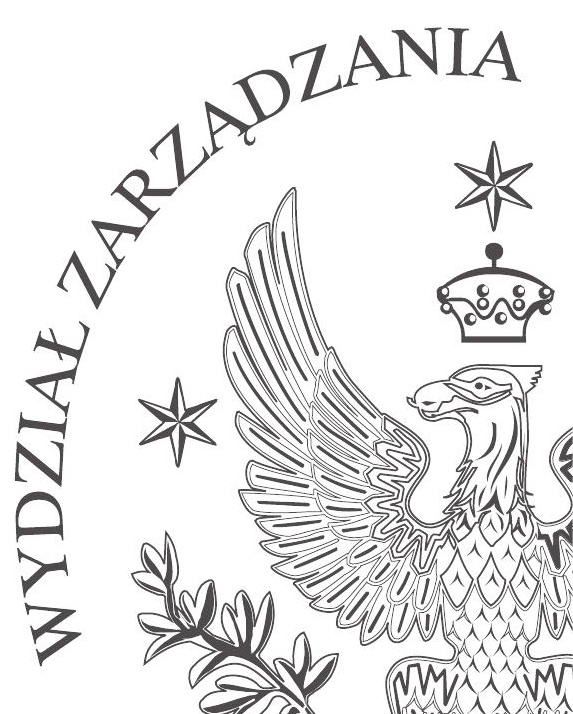


Recenzent: prof. dr hab. Beata Glinka

Redakcja: Anita Sosnowska

Projekt okładki: Agnieszka Miłaszewicz

(C) Copyright by Wydawnictwo Naukowe Wydziału Zarządzania Uniwersytetu Warszawskiego, Warszawa 2020

e-ISBN: 978-83-66282-19-3

https://doi.org/10.7172/978-83-66282-19-3.2020.wwz.2

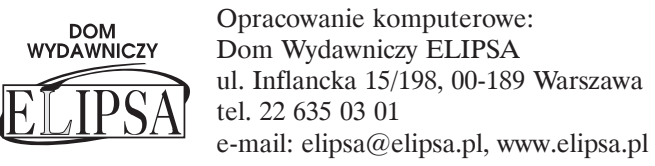




\section{Spis treści}

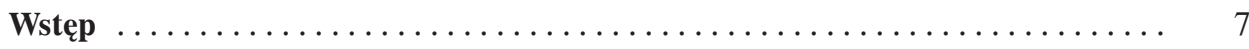

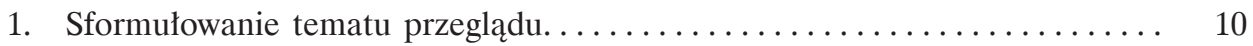

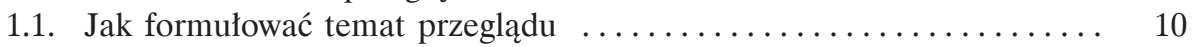

1.2. Jak nie formułować pytania do systematycznego przeglądu

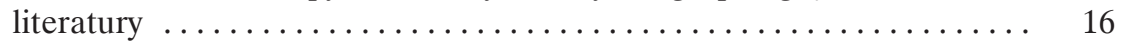

1.3. Poszukiwanie wcześniejszych SPL odpowiadających na pytanie badawcze . . . ............................... 17

1.3.1. Wyszukiwanie ograniczone do pism publikujących jedynie

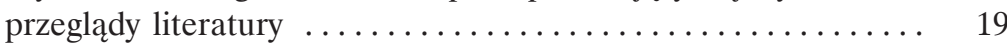

1.3.2. Wyszukiwanie wcześniejszych SPL i meta-analiz ......... 20

1.3.3. Wyszukiwanie przeglądów dowolnego rodzaju .......... 21

2. Ustalenie kryteriów wyszukiwania i kwalifikacji badań do przeglądu ...... 23

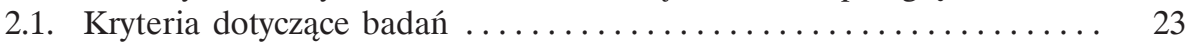

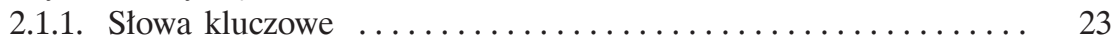

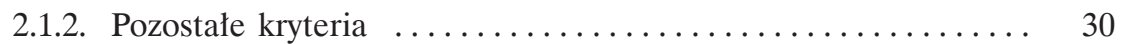

2.2. Kryteria dotyczące źródeł ....................... 32

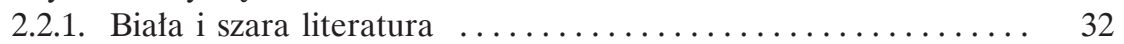

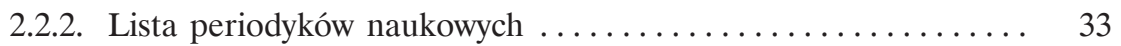

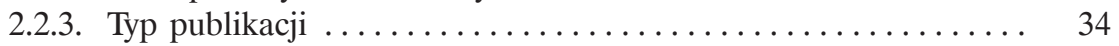

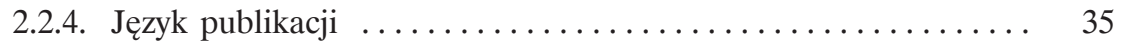

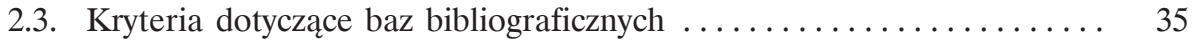

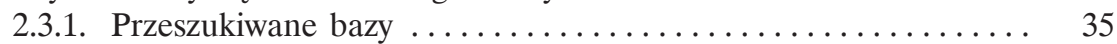

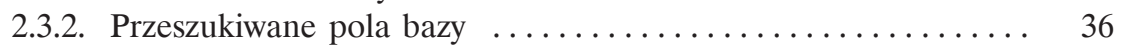

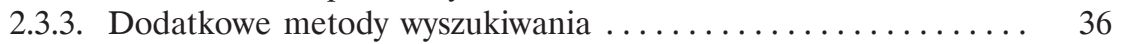

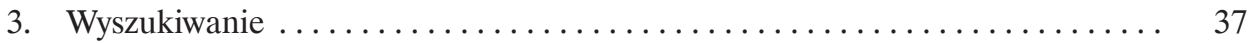

3.1. Przykład 1. Temat SPL: proto-instutucje $\ldots \ldots \ldots \ldots \ldots \ldots \ldots \ldots \ldots$

3.2. Przykład 2. Temat SPL: imitacja ..................... 39

3.3. Przykład 3. Temat SPL: cyberloafing $\ldots \ldots \ldots \ldots \ldots \ldots \ldots \ldots \ldots . \ldots \ldots$

3.4. Przykład 4. Temat SPL: wpływ outsourcingu na wyniki
przedsiębiorstw $\ldots \ldots \ldots \ldots \ldots \ldots \ldots \ldots \ldots \ldots \ldots \ldots \ldots \ldots \ldots \ldots \ldots \ldots \ldots \ldots \ldots \ldots$

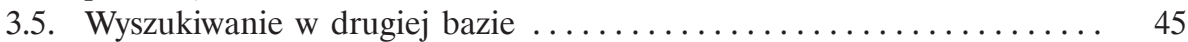

3.6. Pobranie rezultatów wyszukiwania i usuwanie duplikatów ........ 46

4. Kwalifikacja na podstawie tytułów i abstraktów ............... 49

4.1. Niezgodność $z$ tematem SPL ...................... 49

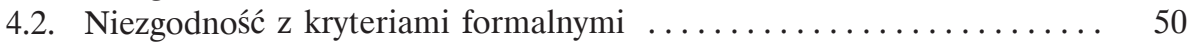

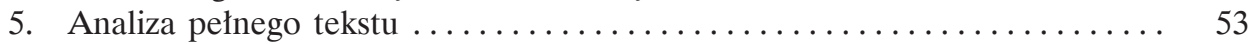

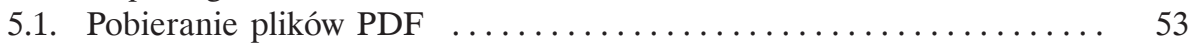


5.2. Usuwanie duplikatów i źródeł niezgodnych z tematem przeglądu ... 57

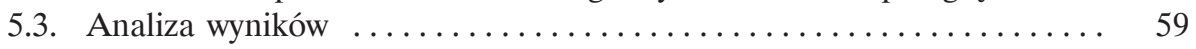

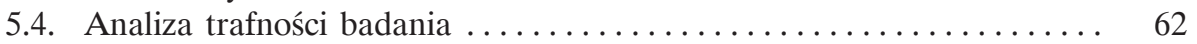

5.4.1. Zagrożenia dla wewnętrznej trafności badania ........... 63

5.4.2. Zagrożenia dla zewnętrznej trafności badania .......... 66

5.4.3. Zagrożenia dla trafność konstruktów .............. 67

5.4.4. Zagrożenia dla trafności inferencji statystycznej ......... 68

5.4.5. Zagrożenia dla trafności fasadowej (zdroworozsądkowej) ... 70

6. Przygotowanie raportu $\mathrm{z}$ systematycznego przeglądu literatury . . . . . . . 73

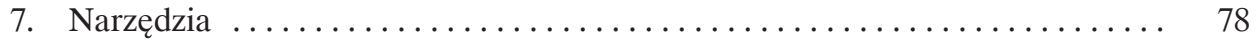

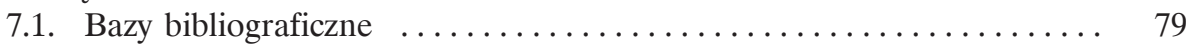

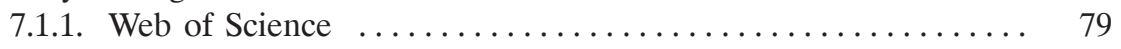

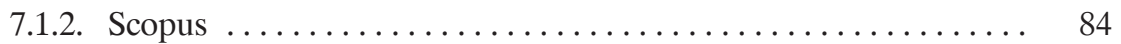

7.1.3. Porównanie zasięgu Web of Science i Scopus ........... 88

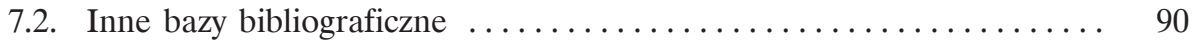

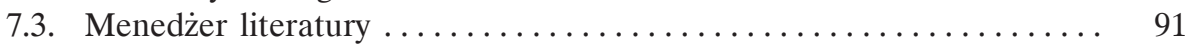

7.3.1. Pobieranie wyników wyszukiwania z Web of Science do Mendeley ........................ 92

7.3.2. Pobieranie wyników wyszukiwania ze Scopus do Mendeley .... 92

7.3.3. Dodawanie plików PDF do danych bibliograficznych ....... 94

7.3.4. Dodawania odwołań bibliograficznych (referencji)

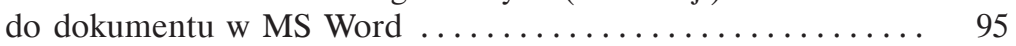

7.4. Pozostałe narzędzia $\ldots \ldots \ldots \ldots \ldots \ldots \ldots \ldots \ldots \ldots \ldots \ldots \ldots \ldots$

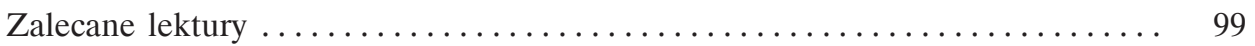

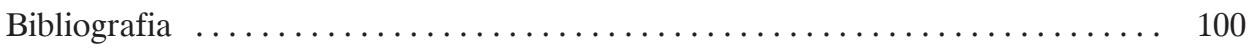




\section{Wstęp}

Celem systematycznego przeglądu literatury (SPL) jest identyfikacja, integracja i ocena badań, dotyczących wybranej tematyki, na podstawie jasno zdefiniowanych kryteriów. Stosowanie tej metodyki sporządzania przeglądu literatury ma zapewnić trzy podstawowe korzyści:

(a) w przeglądzie literatury zostaną uwzględnione wszystkie wyniki badań poświęconych danemu zagadnieniu,

(b) nie zostaną pominięte wyniki badań, które z jakichś powodów nie odpowiadają zamierzeniom czy poglądom badacza,

(c) stworzona zostanie możliwość weryfikacji trafności przeglądu poprzez umożliwienie jego replikacji.

Te trzy cele zostaną osiągnięte, gdy autor systematycznego przeglądu literatury (a) odpowiednio dobierze kryteria wyszukiwania, (b) rzetelnie je przedstawi w końcowym raporcie z przeglądu literatury, (c) prawidłowo przeanalizuje wszystkie odnalezione źródła i (d) właściwie je podsumuje, (e) uwzględniając ograniczenia metodyczne indywidualnych badań omawianych w ramach przeglądu literatury.

Przygotowanie systematycznego przeglądu literatury może stanowić cel sam w sobie, lecz często taki przegląd jest jedynie etapem wstępnym realizacji własnego badania. Jakość tego badania w decydującym stopniu zależy od jakości systematycznego przeglądu literatury. Pominięcie etapu przeglądu literatury lub przeprowadzenie go na podstawie kilkunastu przypadkowo dobranych źródeł może spowodować, że przeprowadzone badanie będzie:

(a) niepotrzebne (odpowiedź na pytanie badawcze jest od dawna znana);

(b) błędnie zaplanowane (nie uwzględniono ważnych zmiennych, o których wiadomo, że wywierają wpływ na badane zjawisko; użyto metod, o których wiadomo, że nie sprawdzają się w danym typie badania);

(c) niewystarczająco osadzone w dotychczasowym dorobku empirycznym (autor badania nie będzie w stanie pokazać czy uzyskane przez niego/nią wyniki pozostają w zgodzie z dotychczasowymi rezultatami, czy je podważają);

(d) niewystarczająco osadzone w dotychczasowych teoriach (autor badania nie uwzględnia ważnych perspektyw teoretycznych lub błędnie łączy ze sobą wyniki uzyskane w ramach odrębnych podejść teoretycznych, które różnią się np. przyjętymi założeniami). 
Systematyczne prowadzenie przeglądu literatury staje się ważniejsze z każdym rokiem. Dwadzieścia, trzydzieści lat temu badacz mógł na bieżąco śledzić wszystkie ważne publikacje i tym samym opierać swoje badania na intuicyjnym rozpoznaniu literatury. W ostatniej dekadzie liczba badań rośnie niemalże w postępie wykładniczym (rysunek 1, rozdział 7), co sprawia, że śledzenie wszystkich ukazujących się publikacji jest niewykonalne. Dlatego też, konieczne jest poprzedzenie każdego projektu badawczego sporządzeniem rzetelnego przeglądu literatury.

Procedura sporządzania systematycznego przeglądu literatury składa się z sześciu etapów, którym odpowiadają poszczególne rozdziały niniejszego poradnika:

1) sformułowanie tematu przeglądu,

2) ustalenie kryteriów wyszukiwania i kwalifikacji badań do przeglądu,

3) wyszukiwanie publikacji w bazach danych,

4) kwalifikacja publikacji na podstawie tytułów i abstraktów,

5) kwalifikacja i analiza badań na podstawie pełnych tekstów,

6) przygotowanie raportu z przeglądu literatury.

Przed przystąpieniem do sporządzania systematycznego przeglądu literatury warto zapoznać się z podstawowymi różnicami między tym a pozostałymi sposobami sumowania dotychczasowych wyników badań.

Większość przeglądów literatury zawartych w typowych tekstach empirycznych przyjmuje postać przeglądów narracyjnych. Tego rodzaju przegląd nie opiera się na jasno zdefiniowanych i przedstawionych czytelnikowi kryteriach. Autor tekstu dobiera publikacje według swojego uznania. Wśród zalet takiego przeglądu można wymienić: a) możliwość pominięcia badań, których związek z tematem jest marginalny lub które — zdaniem autora przeglądu — nie cechują się odpowiedni wysokim poziomem trafności i rzetelności, b) łatwość budowania ciekawej narracji, która prowadzi czytelnika do hipotez i wyników, c) możliwość uwzględnienie rezultatów opublikowanych w specyficznych miejscach/źródłach. Jednak olbrzymią wadą tej metody stanowi łatwość celowego lub przypadkowego pominięcia rezultatów, które są niezgodne z zamiarami/hipotezami/pytaniami sformułowanymi przez badacza.

Zupełnie inny typ przeglądu stanowi metaanaliza, która opiera się na jasno zdefiniowanych kryteriach poszukiwania wcześniejszych rezultatów. Celem metaanalizy jest określenie siły zależności między zmiennymi, natomiast poszukiwania wyników na temat interesującej badacza relacji są przeważnie prowadzone bardzo szeroko - nie są ograniczane do publikacji w pismach naukowych. Najważniejszą zaletą metaanalizy jest możliwość uzyskania najlepiej uzasadnionej wiedzy na temat badanego zjawiska. Niestety, metaanalizy są również naznaczone poważnymi ograniczeniami: dają wąską wiedzę, na ogół dotyczącą jednej relacji między zmiennymi i jej moderatorów. Ponadto, metaanalizy, ze względu 
na swój ilościowy charakter nie pozwalają uwzględnić wyników badań jakościowych.

Ostatni typ to systematyczny przegląd literatury. Jego podstawową zaletą jest systematyczność: przegląd uwzględnia wszystkie wyniki badań, które spełniają kryteria wyszukiwania, a nie tylko te, które pasują do tezy autora przeglądu. Dlatego rezultaty takich przeglądów pozwalają uzyskać najlepszą i zniuansowaną wiedzę o dotychczasowych rezultatach. W związku z tym, że od autorów systematycznych przeglądów literatury wymaga się jasnego zaraportowania kryteriów poszukiwania publikacji, tego rodzaju przegląd jest powtarzalny i dzięki temu weryfikowalny. Niestety, nieodłącznym kosztem stosowania tej metody jest wysoka praco- i czasochłonność. W przypadku dobrze rozwiniętych tematów badawczych sporządzenie przeglądu może zająć wiele miesięcy.

Przed rozpoczęciem pracy nad przygotowaniem systematycznego przeglądu literatury tematu warto wyposażyć się w narzędzia (oprogramowanie i dostęp do baz), które umożliwią zrealizowanie tego zadania. Zostały one opisane w rozdziale 7 . 


\section{Rozdział 1}

\section{Sformułowanie tematu przeglądu}

\subsection{Jak formułować temat przeglądu}

Pierwszym i kluczowym etapem poprawnie sporządzonego systematycznego przeglądu literatury (SPL) jest sformułowanie pytania badawczego. Pytanie badawcze zależy od celu, któremu ma służyć SPL:

- sporządzenie publikacji do pisma naukowego/monografii,

- przygotowanie bazy literaturowej do badania własnego,

- przygotowanie zaleceń dla praktyki (zgodnie z koncepcją evidence-based management (Rousseau, 2012b)).

Sporządzenie SPL jest często etapem wstępnym własnego badania empirycznego i taką perspektywę przyjmuję w dalszej części tego rozdziału. Pozostałe etapy procedury pozostają takie same, niezależne od tego, jaki cel przyświeca SPL. W takiej sytuacji zakres pytania badawczego dla przeglądu literatury powinien pokrywać się z zakresem pytania dla badania empirycznego. $\mathrm{Z}$ tego spostrzeżenia wynikają ważne konsekwencje zarówno dla pytania, na które chcemy odpowiedzieć w systematycznym przeglądzie literatury, jak i dla projektu badania.

W pismach zakwalifikowanych do kategorii „management” opublikowano dotychczas ponad 750000 artykułów, włączenie zaś publikacji z szeroko rozumianych badań nad biznesem oraz psychologii i ekonomii daje łączną liczbę prawie 4000000 artykułów naukowych (rozdział 7).

Wynika z tego, że zbyt szeroko zakreślone pytanie prawdopodobnie zwróci tak dużą liczbę artykułów, że ich przenalizowanie będzie niewykonalne. Tabela 1 przedstawia kilka przykładów źle sformułowanych pytań badawczych. Wszystkie zwracają ponad 5000 wyników. 
Tabela 1. Błędnie sformułowane pytania. Wyszukiwanie przeprowadzono 9.04.2020

\begin{tabular}{l|l|c|}
\multicolumn{1}{c|}{ Pytanie badawcze } & \multicolumn{1}{c|}{ Zapytanie do WoS } & Liczba rezultatów \\
\hline $\begin{array}{l}\text { Co wiemy } \\
\text { o strategiach biznesowych? }\end{array}$ & $\begin{array}{l}\text { TS=(business AND strategy) } \\
\text { TS=(„,business strategy”) }\end{array}$ & 54298 \\
\hline $\begin{array}{l}\text { Co wiemy } \\
\text { o zachowaniach organizacyjnych? }\end{array}$ & $\mathrm{TS}=($ (organi?ational behavio\$r”) & 5717 \\
\hline $\begin{array}{l}\text { Co wiadomo } \\
\text { o strukturach organizacyjnych? }\end{array}$ & $\mathrm{TS}=($,organi?ational structure”) & 8747 \\
\hline
\end{tabular}

Dlatego pytanie badawcze powinno być sformułowane na tyle wąsko, by dało możliwą do przenalizowania liczbę artykułów, ale na tyle szeroko, by liczba znalezionych publikacji mogła stanowić podstawę dla systematycznego przeglądu literatury ${ }^{1}$. Z przytoczonych wyżej danych wynika również, że planując badanie empiryczne, należy unikać zbyt szerokiego sformułowania tematu. Badanie empiryczne, które chce udzielić odpowiedzi na pytania o ogólnym zasięgu prawdopodobnie zakończy się fiaskiem już na etapie sporządzania przeglądu literatury. Jeśli nawet pominiemy ten etap i od razu przejdziemy do przeprowadzenia badania, to uzyskamy rezultaty niskiej jakości, właśnie z powodu pominięcia dotychczasowego dorobku.

Z powyższego wynika, że pytanie badawcze do systematycznego przeglądu literatury powinno dotyczyć wybranego wycinka szerszego zagadnienia teoretycznego. Można ten cel osiągnąć, precyzując ogólny obszar zainteresowań, a następnie znajdując wybrany podobszar badań lub konkretną zależność, którą chcemy zbadać. Oczywiście kosztem takiego zawężenia jest węższy zakres pytań, na które będziemy mogli odpowiedzieć (Siddaway, Wood i Hedges, 2019).

Jednocześnie pamiętajmy, że stworzenie pytania do systematycznego przegląd literatury tematu jest na ogół poprzedzone wstępnymi poszukiwaniami, które pozwolą określić ilość literatury. Te wstępne poszukiwania odgrywają bardzo ważną rolę, ponieważ to dzięki nim pogłębiamy swoją wiedzę o temacie badań i jednocześnie oceniamy, na jaki temat przeglądu (i badania) możemy się zdecydować przy środkach i czasie, którymi dysponujemy.

Podczas lektury opublikowanych przeglądów literatury łatwo dojść do przekonania, że autor przeglądu postawił pytanie badawcze, następnie zalogował się do baz bibliograficznych, odnalazł wszystkie teksty spełniające kryteria wyszukiwania i sporządził SPL. W rzeczywistości proces ustalania pytania do SPL ma charakter iteracyjny - pierwszy pomysł na temat przeglądu jest sprawdzany w bazach bibliograficznych. Na podstawie liczebności odnalezionej literatury

1 Jednocześnie należy pamiętać, że początkowa liczba wyników na ogół zostaje radykalnie zredukowana na kolejnych etapach analizy. Nie jest rzadkością rozpoczęcie SPL od listy 4000 publikacji, która na ostatnim etapie zostaje ograniczona do 100. 
autor doprecyzowuje temat i kryteria wyszukiwania, tak długo aż osiągnie liczbę tekstów, którą będzie w stanie przeanalizować. Jest to normalna praktyka, która nie szkodzi jakości SPL, jeśli autor nie „hakuje” przeglądu, kierując się wyłącznie chęcią ograniczenia liczby publikacji, jednocześnie pomijając wpływ tego działania na jakość przeglądu. Przykładowo, ograniczenie przeglądu poprzez wykluczenie z wyszukiwania pisma naukowego, które opublikowało dużo rezultatów na interesujący nas temat jest zdecydowanie niedopuszczalną praktyką. Natomiast ograniczenie wyników wyszukiwania tylko do badań przeprowadzonych w ramach konkretnej teorii lub w konkretnym przedziale czasowym może być uzasadnione, jeśli w pytaniu badawczym jasno stwierdzimy, że szukaliśmy badań uzyskanych jedynie w ramach tej teorii albo w danym okresie.

W większości przypadków sformułowanie pytania do SPL wymaga wyrażenia go w języku teorii. Wyjątek stanowią (nie zawsze) SPL sporządzone w celu uzyskania praktycznych rekomendacji dla zarządzania. Poniżej przedstawiam trzy scenariusze budowy pytania do SPL: 1) ogólne zainteresowanie teoretyczne zawężone do jednego aspektu teorii/zjawiska (protoinstytucje), 2) zainteresowanie empiryczne zostaje przetłumaczone na język teorii (cyberloafing), 3) pytanie do SPL wynika z zainteresowania praktycznego (outsourcing). Jeśli pominiemy ostatnią kategorię (SPL jako źródło rekomendacji dla praktyki zarządzania), to możemy powiedzieć, że formułowanie pytania badawczego zawsze odbywa się za pośrednictwem teorii, co przedstawia rysunek 1.

Rysunek 1. Proces konkretyzacji pytania do przeglądu literatury
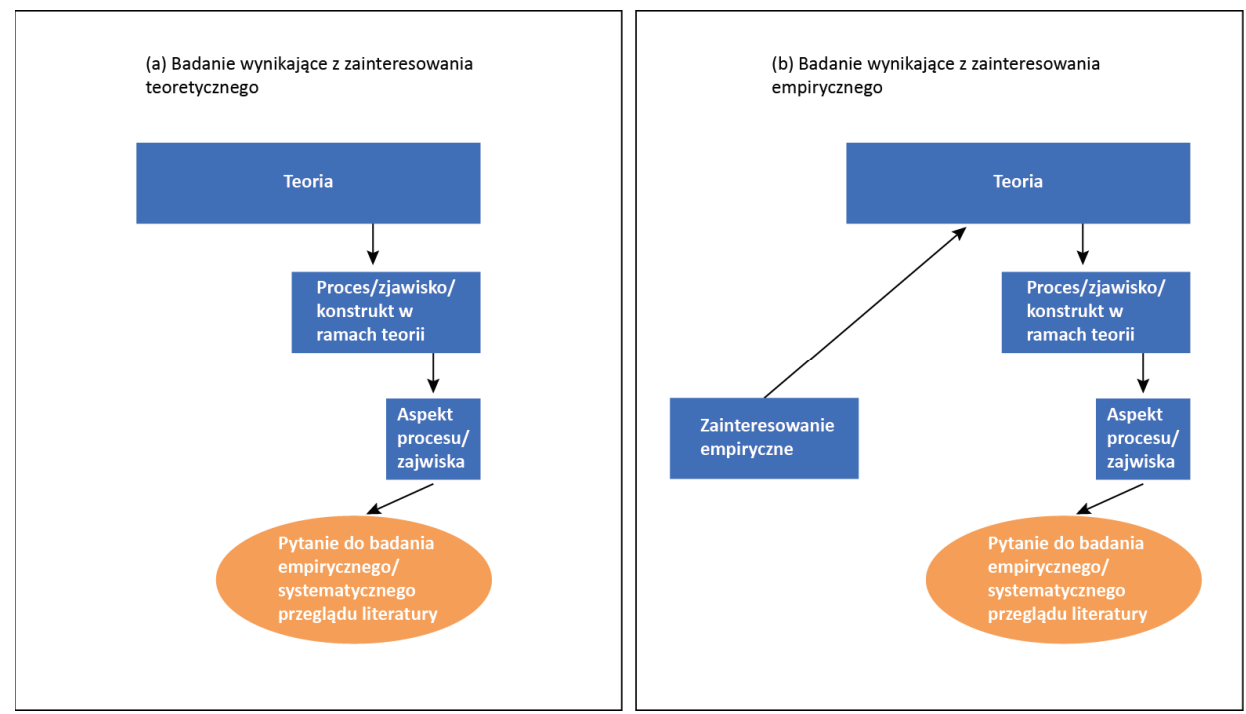


\section{Przykład 1. Ogólny obszar badania zawężony do jednego aspektu badania} (protoinstytucje). Punktem wyjścia jest zainteresowanie teoretyczne. Badacz chciałby rozwinąć teorię neoinstytucjonalną, czyli dominujące obecnie podejście w badaniach organizacji. W szczególności jest zainteresowany badaniem zjawiska instytucjonalizacji, czyli procesu, w ramach którego codzienne praktyki stają się regułami działania i zostają nasycone znaczeniami wykraczającymi poza ich techniczny aspekt. Wstępne przeszukiwanie baz bibliograficznych wskazuje, że literatura dotycząca neoinstytucjonalizmu i procesu instytucjonalizacji jest bardzo obszerna (tabela 2, 4441 rezultatów). Dlatego badacz decyduje się na wybór tylko pewnego fragmentu tego procesu jako swojego obszaru badawczego. Pytanie badawcze ogranicza do pierwszej fazy procesu instytucjonalizacji i postanawia zająć się instytucjami in statu nascendi, które jeszcze nie uzyskały statusu pełnoprawnych instytucji. Zatem ogranicza swoje pytanie badawcze do protoinstytucji (tabela 2, 13 rezultatów), ponieważ taką właśnie nazwę noszą nie w pełni zinstytucjonalizowane praktyki, które go interesują. Jednocześnie jako szersze tło badania przyjmuje literaturę dotyczącą całego procesu instytucjonalizacji (tabela 2, 260 rezultatów), by móc wskazać, w jaki sposób badania poświęcone protoinstytucjom mieszczą się w tym procesie.

Proces przechodzenia od ogólnego zainteresowania badawczego do konkretnego, wąskiego pytania badawczego został zilustrowany w części „a” rysunku 1.

Tabela 2. Ogólny obszar badania zawężony do pytania szczegółowego. Zainteresowanie teoretyczne jako punkt wyjścia

\begin{tabular}{|c|c|c|c|}
\hline Zakres & Pytanie & Search string & $\begin{array}{l}\text { Liczba } \\
\text { rezultatów }\end{array}$ \\
\hline $\begin{array}{l}\text { Ogólny obszar } \\
\text { badania }\end{array}$ & teoria instytucjonalna & $\mathrm{TS}=($,institutional theory”) & 4441 \\
\hline $\begin{array}{l}\text { Podobszar } \\
\text { badania }\end{array}$ & proces instytucjonalizacji & $\begin{array}{l}\text { TS=(“institutional theory") } \\
\text { AND TS=(institutionali?ation) }\end{array}$ & 260 \\
\hline $\begin{array}{l}\text { Szczególowe } \\
\text { pytanie badawcze }\end{array}$ & $\begin{array}{l}\text { co wiadomo } \\
\text { o instytucjach, które } \\
\text { dopiero się kształtują } \\
\text { i nie przeszły przez } \\
\text { wszystkie fazy procesu } \\
\text { instytucjonalizacji, czyli } \\
\text { o protoinstytucjach? }\end{array}$ & $\mathrm{TS}=($ proto-institution $)$ & 13 \\
\hline
\end{tabular}

Przykład 2. Pytanie badawcze wynikające $\mathrm{z}$ zainteresowania empirycznego (cyberloafing). Badacz zauważa, że młodzi ludzie w miejscu pracy często korzystają z komputerów firmowych do przeglądania sieci społecznościowych, oglądania YouTube, wysyłania wiadomości przez komunikatory. Na tej podstawie formułuje swoje wstępne pytanie badawcze: czy pracownicy z Generacji Z są 
bardziej skłonni do korzystania z Internetu w prywatnych celach w miejscu pracy niż pracownicy przynależący do innych generacji?

Jednak poprzestanie na takim sformułowaniu pytania badawczego gwarantuje, że systematyczny przegląd literatury tematu zostanie błędnie przeprowadzony. Poszukiwanie publikacji zawierających takie słowa kluczowe jak „korzystanie z komputera w miejscu pracy w prywatnych celach” i „Generacja Z” pozwoli zidentyfikować jedynie część relewantnej literatury. Ponadto, stworzy wysokie ryzyko, że badanie nie zostanie osadzone w spójnej perspektywie teoretycznej. Możliwe jest nawet, że badacz nie będzie zdawał sobie sprawy z tego, że istnieją różne perspektywy teoretyczne służące opisywaniu tego zjawiska.

W takiej sytuacji konieczne jest przetłumaczenie zainteresowania praktycznego (czy młodzi pracownicy częściej korzystają z Internetu w miejscu pracy w celach prywatnych) na zainteresowanie teoretyczne. Innymi słowy, sporządzenie dobrego przeglądu literatury wymaga przetłumaczenia pojęć potocznych na pojęcia i konstrukty teoretyczne (rysunek 1 , część b). Dzięki temu, osiągniemy cztery cele:

(a) zwiększamy prawdopodobieństwo, że uda się odnaleźć właściwą literaturę;

(b) podnosimy jakość badania empirycznego, ponieważ istniejące teorie pozwalają nam lepiej zrozumieć problem i uwzględnić ważne czynniki odkryte we wcześniejszych badaniach (np. moderatory);

(c) możemy uwzględnić wyniki badań, które nie odnoszą się bezpośrednio do naszego pytania badawczego, ale opisują podobne zjawiska/zachowania (np. czy młodzi pracownicy chętniej niż inni poświęcają czas pracy na nieformalne rozmowy);

(d) zwiększamy szanse, że wyniki naszego badania zostaną opublikowane (pisma naukowe nie są — na ogół - zainteresowane wynikami empirycznymi, interesuje ich rozwijanie teorii; szanse na publikację mają zatem tylko te artykuły, które wykorzystują uzyskane rezultaty empiryczne do budowy teorii; wynika $\mathrm{z}$ tego, że zapoznanie się z teorią jest nieodzownym warunkiem przeprowadzenia dobrego badania).

Wobec powyższego, musimy poszukać teorii, które pozwolą nam wyrazić zainteresowanie praktyczne w języku teoretycznym. W przypadku wykorzystywania Internetu do prywatnych celów w miejscu pracy nasuwają się dwie perspektywy teoretyczne.

1. Oglądanie filmów na YouTube w godzinach pracy oznacza, że pracownik nie może w tym czasie wykonywać swoich obowiązków zawodowych. A więc jest to zachowanie niesprzyjające wydanej pracy. Wobec tego jako perspektywę teoretyczną można przyjąć literaturę na temat counterproductive work behavior (CWB). W ramach tej literatury studiuje się najróżniejsze zachowania (spóźnienia, wychodzenia z miejsca pracy w godzinach urzędowania, sabotaż, rozsiewanie plotek i wiele innych), które nie sprzyjają wydajnej pracy. 
Wstępne przeszukanie literatury wskazuje, że wykorzystywanie Internetu w pracy do prywatnych celów jest również zaliczane do tej kategorii zachowań. Możemy zatem wykorzystać literaturę na temat CWB jako podstawę teoretyczną naszego badania. Co więcej, wstępna inspekcja tej literatury ujawnia, że istnieje specjalistyczne pojęcie, które służy do nazwania tego zjawiska: cyberloafing (Lim, 2002). To pojęcie możemy wykorzystać jako podstawę naszego wyszukiwania. Możemy też poszukiwać dalej i zauważyć, że cyberloafing jest często badany w ramach theory of planned behavior (Ajzen, 1985, 1991; Askew i in., 2014) i perspektywy ego depletion (Barnes, Schaubroeck, Huth i Ghumman, 2011; Baumeister, 2002; Baumeister, Bratslavsky, Muraven i Tice, 1998) i właśnie te perspektywy teoretyczne wykorzystać jako podstawę pytania badawczego.

2. Internet jest w dalszym ciągu traktowany jako nowa technologia, jako punkt wyjścia dla naszych poszukiwań możemy więc także wykorzystać najpopularniejszy model wdrażania i akceptacji nowych technologii, tj. Unified Theory of Acceptance and Use of Technology (UTAUT) (Venkatesh, Morris, Davis i Davis, 2003). Po wstępnym przejrzeniu literatury poruszającej zagadnienie korzystania z Internetu w prywatnych celach w miejscu pracy i wykorzystującej model UTAUT natychmiast spostrzeżemy, że (a) ta literatura również posługuje się pojęciem „cyberloafing” oraz że (b) interesujące nas zjawisko jest w modelu UTUAT postrzegane w zupełnie inny sposób. Badacze prowadzący badania w ramach tej perspektywy badawczej w mniejszym stopniu są zainteresowani wpływem cyberloafingu na wydajność. Koncentrują swoją uwagę na tym, że cyberloafing może stanowić zagrożenie dla systemów informatycznych przedsiębiorstwa, samo zjawisko analizują zaś w kontekście information security policy (polityka bezpieczeństwa informacji/systemu informatycznego) (Chen, Ramamurthy i Wen, 2012; Cheng, Li, Li, Holm i Zhai, 2013; Khansa, Barkhi, Ray i Davis, 2017; Khansa, Kuem, Siponen i Kim, 2017; Moody, Siponen i Pahnila, 2018).

Odkrywszy te dwa nurty teoretyczne, autor badania musi zadecydować, który z nich jest bardziej interesujący i na podstawie tej decyzji sformułować ostateczne pytanie do przeglądu literatury. Niezależnie od wybranej teorii głównym słowem wyszukiwawczym będzie „cyberloafing”, jednak od wyboru konkretnej teorii zależy, jakie ograniczenia i rozszerzenia do tego słowa dodamy. Na przykład, jeśli bardziej interesuje nas druga z wyżej wymienionych perspektyw (UTAUT) musimy włączyć do wyszukiwania także publikacje pokonferencyjne. Jest tak dlatego, że w propagowaniu wyników badań dotyczących IT publikacje pokonferencyjne odgrywają znacznie większą rolę niż w naukach o zarządzaniu.

Przykład 3. Pytanie wynikające z zainteresowania praktycznego (outsourcing). Metoda systematycznego przeglądu literatury powstała z powodów stricte praktycznych: naukowcy zajmujący się medycyną stworzyli metodę, która miała 
wskazywać najlepsze sposoby leczenia pacjentów na podstawie rzetelnej analizy dostępnych wyników badań. Odpowiednikiem tej perspektywy w ramach nauk o zarządzaniu są systematyczne przeglądy literatury zorientowane na dostarczenie wiedzy menedżerskiej opartej na dowodach (evidence-based management) (Briner i Walshe, 2014; Pfeffer i Sutton, 2006; Rousseau, 2012a). Trzeci przykład omawia taki właśnie przypadek. Menedżer ma podjąć decyzję o skorzystaniu z outsourcingu i chce się dowiedzieć czy ta metoda przynosi pozytywne wyniki (performance). W tej sytuacji nie ma konieczności tłumaczenia pytania praktycznego na pytanie sformułowane w języku naukowym. Można posłużyć się pojęciami wziętym z praktyki (outsourcing AND performance) jako podstawowym ciaggiem wyszukiwawczym.

\subsection{Jak nie formułować pytania do systematycznego przeglądu literatury}

Częstym błędem popełnianym podczas formułowania pytania do systematycznego przeglądu literatury jest nadmierna szczegółowość pytania połączona z niewystarczającą precyzją stwierdzeń (Briner i Denyer, 2012). Przykładowo, autor formułuje pytanie:

Co wiemy o metodach motywowania pracowników w przemyśle motoryzacyjnym $w$ Polsce?

To pytanie jest sformułowane błędnie, ponieważ zawiera dwie ukryte hipotezy i jednocześnie jest nieprecyzyjne. Pierwsza ukryta hipoteza mówi, że pracownicy przemysłu motoryzacyjnego są motywowani inaczej niż pracownicy innych przemysłów, co może być prawdą, ale nie musi. Jednak zawarcie takiego ograniczenia już w pytaniu badawczym powoduje, że autorzy nie zauważą, iż opisują zjawisko o znacznie szerszym zasięgu niż przemysł motoryzacyjny. Co za tym idzie, będą mieli problemy ze znalezieniem odpowiedniej literatury - spośród tysięcy publikacji poświęconych zagadnieniom motywacji, tylko znikoma liczba dotyczy pracowników przemysłu motoryzacyjnego. Druga ukryta hipoteza zakłada, że motywacja pracowników przemysłu motoryzacyjnego wygląda w Polsce inaczej niż w innych krajach, co ponownie może być prawdą, ale nie musi. Ta ukryta hipoteza pociaga za sobą te same problemy, co pierwsza. Ponadto, pytanie jest sformułowane nieprecyzyjnie, ponieważ nie określono o jaką kategorię pracowników chodzi. Można podejrzewać, że pracownicy zatrudnieni przy taśmie produkcyjnej są motywowani za pomocą innych narzędzi niż menedżerowie czy inżynierowie i projektanci tworzący nowe modele samochodów.

Punktem wyjścia dla dobrze sformułowanego pytania byłoby rozpoczęcie od zakreślenia szerokiego zakresu pytania, na przykład:

Co wiemy o metodach motywowania pracowników w przemyśle? 
Na podstawie wstępnej analizy literatury precyzujemy pytanie:

Co wiemy o metodach motywowania inżynierów w przemyśle?

Dopiero po odnalezieniu literatury do tak sformułowanego pytania możemy prowadzić robocze zawężenie tematyki pytania. W tym celu, w odnalezionej literaturze szukamy słów kluczowych odnoszących się do przemysłu motoryzacyjnego oraz słów identyfikujących lokalizację zakładów przemysłowych w Polsce. Jak widać na rysunku 2, literatura odnaleziona na podstawie błędnie sformułowanego pytania badawczego stanowi tylko niewielki ułamek wszystkich badań, które powinniśmy uwzględnić w systematycznym przeglądzie literatury. Tak wąsko zakreślony zakres pytania spowoduje, że znajdziemy ubogą literaturę, która nie będzie przydatna do zaplanowania badania i interpretacji jego wyników.

Z zaleceń przedstawionych powyżej nie wynika, że nie należy badać metod motywacji stosowanych w przemyśle motoryzacyjnym w Polsce. Wynika zaś, że takie badania należy poprzedzić poszukiwaniem literatury tematu zakrojonym znacznie szerzej niż wstępnie sformułowane pytania badawcze.

\section{Rysunek 2. Liczba rezultatów poszczególnych pytań badawczych}

Co wiemy o metodach motywowania pracowników w przemyśle?

Co wiemy o metodach motywowania

inżynierów w przemyśle?

Co wiemy o metodach motywowania

inżynierów w przemyśle motoryzacyjnym?

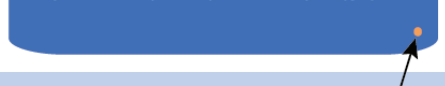

Co wiemy o metodach motywowania inżynierów w przemyśle motoryzacyjnym w Polsce?

\subsection{Poszukiwanie wcześniejszych SPL odpowiadających na pytanie badawcze}

Koniecznym stadium pierwszego etapu sporządzania systematycznego przeglądu literatury jest poszukanie wcześniejszych przeglądów literatury na interesujący nas temat. Pominięcie tej fazy sporządzania SPL naraża nas na trzy problemy: 
a) wykonamy niepotrzebną pracę - systematyczny przegląd literatury na interesujący nas temat być może już istnieje, więc nie ma konieczności sporządzać nowego;

b) sporządzimy zbyt obszerny przegląd literatury - jeśli SPL na interesujący nas temat już istnieje, ale został opublikowany 5 czy 10 lat temu to wystarczy sporządzić SPL dla publikacji wydanych w ciągu ostatnich 5 czy 10 lat; innymi słowy, zamiast sporządzać SPL od zera, przygotowujemy jedynie jego aktualizację;

c) sporządzimy przegląd, który trudno będzie opublikować - jak zauważyłem na wstępie tego rozdziału, SPL są często sporządzane nie jako wstęp do własnego badania, lecz jako samodzielna publikacja; jeśli SPL na temat, który nas interesuje został stosunkowo niedawno opublikowany, to nasz SPL będzie miał nikłe szanse na publikację w dobrym piśmie naukowym.

Wcześniejsze przeglądy literatury będą bardzo pomocne, nawet jeśli nie mają one postaci przeglądu systematycznego. Lektura takiego przeglądu da nam bowiem możliwość zapoznania się $\mathrm{z}$ najważniejszymi nurtami teoretycznymi, zależnościami, zmiennymi kontrolnymi, które dotychczas były badane oraz metodami badawczymi, które wykorzystywano do ich studiowania. Nawet jeśli narracyjny przegląd literatury nie obejmuje wszystkich opublikowanych źródeł, to i tak stanowi bardzo dobry punkt wyjścia do udoskonalenia pytania badawczego dla SPL, który zamierzamy sporządzić.

Wcześniejszych przeglądów literatury najlepiej poszukiwać na trzy sposoby:

a) szybkiego wyszukiwania ograniczonego do pism publikujących jedynie przeglądy literatury - otrzymamy niewielką liczbę rezultatów, które będziemy mogli szybko przejrzeć;

b) poszukiwania ograniczonego do systematycznych przeglądów i metaanaliz otrzymamy większą liczbę rezultatów, których przejrzenie pozwoli stwierdzić czy istnieją już SPL na interesujący nas temat;

c) szerokiego poszukiwania wszystkich typów przeglądów - znajdziemy wszystkie publikacje, które zostały w bazach bibliograficznych oznaczone jako przeglądy literatury na interesujący nas temat. To wyszukiwanie będzie pomocne, jeśli dwa pierwsze wyszukiwania nie przyniosły rezultatu. Prawdopodobnie nie pozwoli ono znaleźć systematycznych przeglądów literatury, których nie znaleźlibyśmy w pierwszych dwóch wyszukiwaniach, ale być może pozwoli znaleźć jakikolwiek przegląd, który wykorzystamy do lepszego zapoznania się $\mathrm{z}$ tematyką. 


\subsubsection{Wyszukiwanie ograniczone do pism publikujących jedynie przeglądy literatury}

Pierwszym etapem sprawdzenia czy SPL na interesujący nas temat już istnieje jest poszukiwanie przeglądów literatury (systematycznych, tradycyjnych oraz metaanaliz) w pismach, które trudnią się publikacją wyłącznie takich opracowań. W przypadku nauk o zarządzaniu (ogólnych) należy wskazać tu na dwa pisma Academy of Management Annals oraz International Journal of Management Reviews (tabela 3).

Oba pisma zajmują się publikowaniem wysokiej jakości przeglądów literatury, przy czym IJMR publikuje stosunkowo często przeglądy systematyczne, natomiast AMA przede wszystkim przeglądy narracyjne. Pamiętajmy, że jeśli zamierzamy opublikować nasz SPL jako samodzielny artykuł (tzn. niezawierający części empirycznej), to odnalezienie nawet niesystematycznego (tradycyjnego) przeglądu literatury, w którymś z tych dwóch pism powinno być dla nas sygnałem, że publikacja naszego SPL może być trudna.

Tabela 3. Pisma naukowe publikujące przeglądy literatury w naukach o zarządzaniu

\begin{tabular}{|c|c|c|c|}
\hline Pismo & ISSN & e-ISSN & $\begin{array}{l}\text { Składowa zapytania } \\
\text { do Web of Science }\end{array}$ \\
\hline Academy of Management Annals & $1941-6520$ & $1941-6067$ & $\mathrm{IS}=(1941-6520$ OR 1941-6067) \\
\hline $\begin{array}{l}\text { International Journal } \\
\text { of Management Reviews }\end{array}$ & $1460-8545$ & $1468-2370$ & $\mathrm{IS}=(1460-8545$ OR $1468-2370)$ \\
\hline
\end{tabular}

Wcześniejszych przeglądów literatury opublikowanych w tych pismach poszukujemy, posługując się ciągami wyszukiwawczymi przedstawionymi w tabeli 4 . Zaletą tej metody jest łatwość i szybkość - nie musimy zastanawiać się, w jaki sposób ograniczyć wyszukiwanie do wcześniejszych przeglądów literatury, ponieważ przeszukiwane pisma publikują wyłącznie przeglądy literatury. Otrzymamy też stosunkowo niewielką liczbę wyników, którą łatwo będzie przejrzeć. Wadą jest oczywiście fragmentaryczność wyszukiwania - z pewnością istnieją przeglądy literatury opublikowane w innych miejscach. Jak widać, tylko w przypadku bardzo popularnej techniki zarządzania jaką jest outsourcing znaleźliśmy wcześniejsze przeglądy (tabela 4). 
Tabela 4. Szybkie wyszukiwanie dla przykładowych tematów przedstawionych w rozdziale 1

Przykład z sekcji 1.1.

Zapytanie do Web of Science

Liczba

rezultatów

$\mathrm{TS}=($ proto-institution $)$ AND IS $=(1941-6520$ OR

1941-6067 OR 1460-8545 OR 1468-2370)

$\mathrm{TS}=$ (cyberloafing) AND IS $=(1941-6520 \mathrm{OR}$

1941-6067 OR 1460-8545 OR 1468-2370)

TS $=$ (outsourcing AND performance) AND

outsourcing

0

0

4 1468-2370)

\subsubsection{Wyszukiwanie wcześniejszych SPL i metaanaliz}

W drugim etapie wyszukiwania wcześniejszych przeglądów literatury nie nakładamy ograniczenia na miejsce publikacji (pismo), co spowoduje, że a) będziemy musieli stworzyć dodatkowe kryteria wyszukiwania oraz b) uzyskamy sporą liczbę wyników, które trzeba będzie przejrzeć, by odnaleźć wcześniejsze przeglądy.

Dodatkowe kryteria wyszukiwania są konieczne, ponieważ bez ograniczenia wyszukiwania znajdziemy wszystkie publikacje zawierające słowa kluczowe, a nie tylko te, które referują przeglądy literatury tematu. Po pierwsze, musimy sprecyzować, że poszukujemy SPL („systematic review”). Po drugie, szukamy również metaanaliz, które co prawda mają inny cel niż SPL, ale również opierają się na zasadzie uwzględniania wszystkich badań związanych z danym tematem, a więc można je wykorzystać jako podstawę naszego badania. W tym celu do ciągu wyszukiwania dodajemy słowa „meta-analy*” i „metaanaly*”. Jak pamiętamy (rozdział 7, tabela 4) gwiazdka (,") zastępuje dowolny ciąg znaków, a więc pozwala nam wyszukać zarówno artykuły, które zawierają słowo „meta-analysis”, jak i „meta-analyses” (liczba mnoga) oraz „meta-analytic” i „meta-analytical” (przymiotniki). Do ciągu wyszukiwania wpisujemy zarówno postać z myślnikiem („meta-analysis”), jak i bez myślnika („metaanalysis”) ponieważ naukowcy nie mogą się zdecydować, która forma jest właściwa i używają obu. W przypadku wyszukiwarki Scopus, wystarczy podać jedną formę („meta-analysis”) ponieważ ta baza automatycznie poddaje słowa kluczowe lemmatyzacji (patrz sekcja 7.1.2). 
Tabela 5. Pełne wyszukiwanie dla przykładowych pytań badawczych przedstawionych w rozdziale 1

Przykład z sekcji 1.1.

\section{proto-institution}

cyberloafing

outsourcing
Ciąg wyszukiwania

Liczba

rezultatów

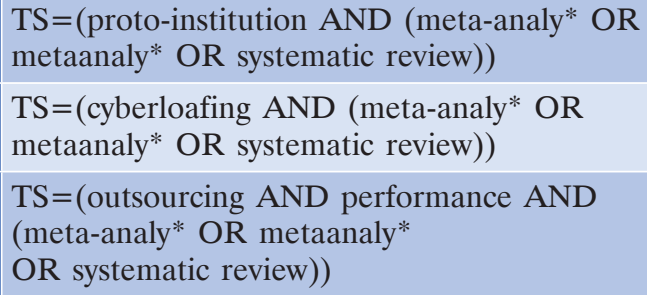

$\mathrm{TS}=$ (proto-institution AND (meta-analy* OR metaanaly* OR systematic review))

TS $=$ (cyberloafing AND (meta-analy* OR metaanaly* OR systematic review))

$\mathrm{TS}=$ (outsourcing AND performance AND

(meta-analy* OR metaanaly*

OR systematic review))

Jeśli uda nam się znaleźć wcześniejszy systematyczny przegląd literatury, który opublikowano w ciągu ostatnich 2-5 lat, to możemy zakończyć nasze wysiłki. Sporządzanie nowego przeglądu nie ma uzasadnienia, lepiej oprzeć się na podsumowaniu wyników, które udało nam się odnaleźć.

Jeśli znajdziemy SPL opublikowany ponad 5-10 lat temu, to powinniśmy sporządzić aktualizację przeglądu, analizując publikacje, które ukazały się po dacie sporządzenia znalezionego przez nas SPL. Uwaga: proces wydawniczy w pismach w naukach o zarządzaniu jest czasami bardzo długi. Między zgłoszeniem tekstu do pisma a jego publikacją mogą upłynąć 2 lata lub więcej. W takiej sytuacji autorzy SPL są przeważnie proszeni przez redakcję o zaktualizowanie przeglądu przed publikacją. Niemniej, określając okres, dla którego sporządzimy aktualizację przeglądu powinniśmy jako datę początkową wybrać datę sporządzenia odnalezionego przeglądu, a nie jego publikacji.

Jeśli nie znajdziemy systematycznego przeglądu, ale uda nam się znaleźć przegląd narracyjny (niesystematyczny), to przed przystąpieniem do sporządzenia SPL powinniśmy przeanalizować miejsce publikacji odnalezionego tradycyjnego przeglądu. Jeśli przegląd ukazał się na łamach dobrego pisma (wspomniane wcześniej AMA i IJMR oraz inne pisma należące do Q1 WoS), to szanse na opublikowanie SPL w dobrym, a nawet przeciętnym piśmie są niewielkie. W takiej sytuacji sporządzanie SPL ma sens tylko, jeśli będzie on stanowił podstawę badania własnego.

\subsubsection{Wyszukiwanie przeglądów dowolnego rodzaju}

Jeśli nie udało nam się znaleźć żadnych wcześniejszych SPL ani metaanaliz, to musimy SPL sporządzić samodzielnie. W takiej sytuacji wielką pomocą będzie dla nas odnalezienie jakiegokolwiek przeglądu - nie po to, by ograniczyć zakres naszego SPL, lecz po to, by lepiej zapoznać się z problematyką, dla której 
chcemy sporządzić SPL. Wszystkich przeglądów możemy szukać, posługując się słowem/słowami kluczowymi oraz wybierając jako typ dokumentu „review”.

Tabela 6. Wyszukiwanie z wykorzystaniem pola Document Type (DT) dla przykładowych pytań badawczych przedstawionych w rozdziale 1

Przykład z sekcji 1.1.

Ciąg wyszukiwania
Liczba rezultatów $\mathrm{TS}=($ proto-institution $)$ AND DT $=($ review $)$
$\mathrm{TS}=($ cyberloafing $)$ AND DT $=($ review $)$
$\mathrm{TS}=($ outsourcing AND performance $)$ AND
$\mathrm{DT}=($ review $)$

Jak widać $\mathrm{z}$ danych przedstawionych $\mathrm{w}$ tabeli 5, uzyskujemy znacznie więcej wyników, co jest zrozumiałe, ponieważ szukaliśmy przeglądów jakiegokolwiek typu, a nie jedynie przeglądów systematycznych i metaanaliz. Inspekcja wyników pokazuje, że wiele z tekstów zakwalifikowanych przez Web of Science jako przeglądy w rzeczywistości prezentuje rezultaty pojedynczych badań empirycznych. Wynika z tego ważna lekcja: nie powinniśmy przesadnie ufać wszelkim kategoryzacjom sporządzonym przez pracowników firm tworzących bazy bibliograficzne czy nawet przez redakcje periodyków naukowych. Najlepszą podstawą do zakwalifikowania tekstu do SPL jest treść samego artykułu.

Jeśli prowadziliśmy wyszukiwania w kolejności przedstawionej w tej sekcji, to analizę wyników uzyskanych w trzecim kroku możemy znacznie ułatwić wyłączając z wyszukiwania artykuły, które już przejrzeliśmy w kroku 1 i 2 . W tym celu wykorzystamy operacje na wynikach wyszukiwania (sekcja 7.1.1). Przyjmując, że wyszukiwanie w pismach AMA i IJMR zostały zapisane w zbiorze $\mathrm{nr}$ 1, wyszukiwanie SPL i metaanaliz w zbiorze $\mathrm{nr}$, natomiast wyszukiwanie wszystkich typów przeglądów w zbiorze nr 3 możemy wykluczyć wyniki pierwszego i drugiego wyszukiwania za pomocą zapytania:

\#3 NOT \#2 NOT \#1 


\section{Rozdział 2}

\section{Ustalenie kryteriów wyszukiwania i kwalifikacji badań do przeglądu}

Odnalezienie w bazach bibliograficznych publikacji, które powinny zostać omówione w SPL wymaga skonstruowania ciągu wyszukiwawczego (zapytanie do bazy, search string). Jego kształt wynika z kryteriów wyszukiwania i kwalifikacji badań do przeglądu, które formulowane są w drugim etapie procedury.

Należy określić kryteria wyszukiwania dla: a) badań, b) źródeł, w których będziemy ich poszukiwać oraz c) baz bibliograficznych, w których będziemy prowadzić kwerendę.

\subsection{Kryteria dotyczące badań}

\subsubsection{Słowa kluczowe}

Wśród kryteriów wyszukiwania, które musimy ustalić najważniejsze miejsce zajmują kryteria dotyczące treści wyszukiwanych publikacji. W rozdziale 1 pokazałem, w jaki sposób powinniśmy formułować pytanie badawcze. W każdym z przykładów słowem kluczowym stanowiącym podstawę wyszukiwania było pojedyncze określenie (,proto-institution”, „cyberloafing”, „outsourcing”). Niestety, posługiwanie się tylko jednym słowem kluczowym i w tylko w jednej formie nie pozwoli odnaleźć wszystkich badań, które powinny zostać uwzględnione w SPL. Dlatego konieczne jest przeprowadzenie wstępnego wyszukiwania, pozwalającego zidentyfikować inne słowa kluczowe, które mogą być wykorzystywane przez autorów badań do zakomunikowania tej samej lub podobnej treści. Nie istnieje jeden, najlepszy sposób realizacji tego celu. Można posiłkować się metodami: słownikową i analizą rezultatów wstępnego wyszukiwania.

\subsubsection{Metoda słownikowa}

Najprostszym, co nie znaczy, że najlepszym rozwiązaniem jest posłużenie się słownikiem wyrazów bliskoznacznych do odnalezienia synonimów intersującego 
nas słowa kluczowego. W tym celu, odwiedzamy któryś z dostępnych w Internecie słowników wyrazów bliskoznacznych (thesaurus), np. www.merriam-webster. com/thesaurus lub www.thesaurus.com, a następnie wpisujemy interesujące nas pojęcie.

Przykład 1. Imitacja rozwiązań organizacyjnych. W związku z tym, że dla żadnego z wcześniej omawianych słów kluczowych („proto-institution”, „cyberloafing”, „outsourcing”) nie istnieją synonimy, posłużę się nowym przykładem. Przypuśćmy, że chcemy przeprowadzić SPL na temat imitacji rozwiązań organizacyjnych - celem jest zebranie wszystkich badań, w których autorzy analizują, w jaki sposób, dlaczego, w jakich warunkach jedne organizacje naśladują inne. Po wprowadzeniu do thesaurusa słowa „imitate” uzyskamy długą listę bliższych i dalszych synonimów. Dokładna lektura tej listy pozwoli nam zidentyfikować pojęcia, które możemy uznać za bliskie naszemu słowu kluczowemu („mimic”, „emulate”, „reproduce”, „replicate”). Tworzymy również ich formę rzeczownikową („mimesis”, „emulation”, „reproduction”, „replication”). Tę listę wykorzystujemy jako zestawienie potencjalnych słów-kandydatów do ciągu wyszukiwawczego. Musimy jednocześnie pamiętać, że nawet drobne różnice znaczeniowe między synonimami mogą istotnie zniekształcić rezultaty kwerendy.

\subsubsection{Metoda analizy rezultatów wstępnego wyszukiwania}

Lepsze rezultaty uzyskamy, analizując teksty, które odnaleźliśmy podczas wstępnego wyszukiwania. Celem takiego wyszukiwania nie jest uzyskanie kompletnej listy publikacji, lecz jedynie odnalezienie publikacji, które posłużą jako źródło wiedzy o tym, jakich pojęć użyć w ostatecznym zapytaniu.

Dlatego wyszukiwanie możemy ograniczyć do najlepszych pism z interesującej nas dziedziny. Dzięki temu otrzymamy stosunkowo niewielką liczbę publikacji i jednocześnie będą to publikacje, które wywierają największy wpływ na środowisko badawcze. Można przyjąć, że słowa kluczowe, którymi posługują się autorzy tych tekstów są prawdopodobnie wykorzystywane również przez autorów publikujących w mniej prestiżowych periodykach. Dobrą regułą jest ograniczanie wstępnego wyszukiwania do górnego kwartyla (Q1) pism z listy Web of Science. W związku z tym, że WoS indeksuje 217 pism z dziedziny zarządzanie, w Q1 znajdzie się 55 pism.

Przykład 1. Imitacja - ciąg dalszy. Wstępne wyszukiwanie przeprowadzamy, posługując się zapytaniem składającym się z dwóch elementów: słowa kluczo- 
wego, które stanowi punkt wyjścia dla poszukiwań („imitation”) oraz numerów ISSN 155 pism z Q1 WoS:

TS=(imitation) AND IS=(1941-6520 OR 0363-7425 OR 0149-2063 OR
1086-0266 OR 0001-8392 OR 0272-6963 OR 0047-2506 OR 1460-8545 OR
0001-4273 OR 2327-0608 OR 1523-2409 OR 0031-5826 OR 1094-4281 OR
0964-4733 OR 0261-5177 OR 0022-2380 OR 0017-8012 OR 1048-9843 OR
0143-2095 OR 1535-3958 OR 0048-7333 OR 0305-0483 OR 0166-4972 OR
0960-0035 OR 0021-9010 OR 0008-1256 OR 0894-3796 OR 0019-8501 OR
1936-9735 OR 0263-7863 OR 1367-3270 OR 0276-7783 OR 1359-8546 OR
0025-1909 OR 0378-7206 OR 0144-3577 OR 2041-3866 OR 1044-5005 OR
0892-9912 OR 0963-8687 OR 0959-6119 OR 0191-3085 OR 1558-9080 OR
2212-571X OR 0737-6782 OR 1469-1930 OR 0266-2426 OR 1053-4822 OR
0921-898X OR $1019-6781$ OR 0170-8406 OR 0964-8410)

Kwerenda zwraca 300 wyników. Gdyby było ich mniej (20-40), moglibyśmy przejrzeć wszystkie. W przypadku dużej liczby wyników w pierwszym etapie staramy się odnaleźć najbardziej obiecujące teksty, to znaczy takie, które dostarczają najlepszych wskazówek co do słów kluczowych. W tym celu sortujemy teksty według liczby cytowań (od najczęściej cytowanych do najrzadziej cytowanych) (rysunek 1, ramka 4). Następnie zaznaczamy wyniki z pierwszej strony rezultatów („Select Page”, ramka 2). Dodajemy zaznaczone rezultaty do listy („Add to Marked List”, ramka 3). W ten sposób, dziesięć najczęściej cytowanych tekstów posługujących się słowem kluczowym trafi na listę publikacji, które chcemy przejrzeć. Następnie powtarzamy całą operację, ale zaczynając od sortowania na podstawie daty publikacji (od najnowszych do najstarszych, ramka 1) i wykonując czynności 2 i 3. Klikając w „Marked List” (ramka 5) otrzymujemy widok listy 20 tekstów, które wywarły największy wpływ na badania nad imitacją oraz tych, które ukazały się niedawno. Na tej podstawie będziemy mogli sobie wyrobić pojęcie o słowach kluczowych wykorzystywanych w badaniach nad interesującym nas zagadnieniem. Listę możemy pobrać do menedżera referencji (np. Mendeley) i przystąpić do pobierania tekstów (plików PDF) i ich lektury.

1 Zamiast numerów ISSN możemy również użyć tytułów pism. W takim wypadku zamiast pola „IS” posłużymy się polem „SO” (source). Jednak ryzykujemy, że w naszym wyszukiwaniu znajdą się rezultaty z pism, które noszą tytuły podobne do tych, które zamierzaliśmy uwzględnić w wyszukiwaniu. 


\section{Rysunek 1. Sortowanie wyników wstępnego wyszukiwania}

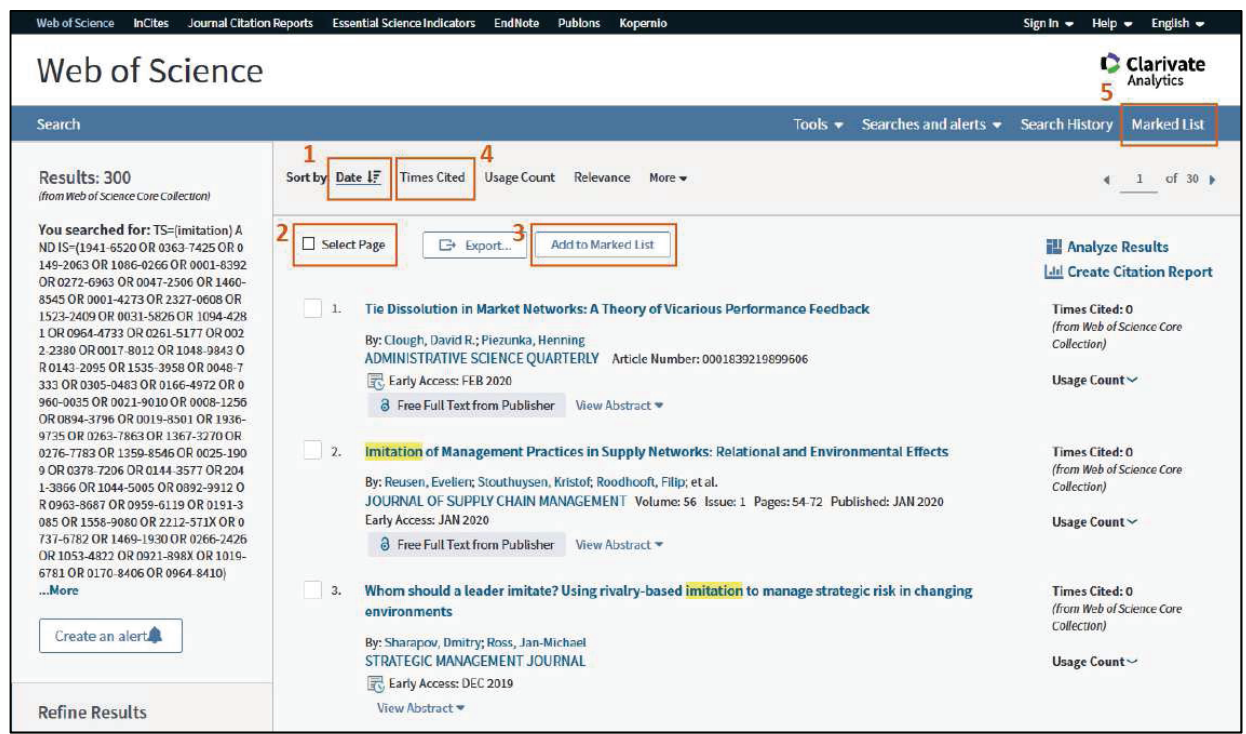

Lektura tych publikacji pozwoli nam odkryć nowe słowo kluczowe: ,isomorphism”, które oznacza proces upodabniania się organizacji do siebie (DiMaggio i Powell, 1983). Odkryjemy też, że dwa synonimy zidentyfikowane dzięki metodzie słownikowej („emulate” oraz „mimic”) są wykorzystywane przez badaczy imitacji, więc należy je rozważyć jako kandydatów do ostatecznej wersji zapytania. Przy okazji odkrywamy, że równie często używany jest przymiotnik „mimetic”, który również włączamy do wyszukiwania. Wstępnie weryfikujemy sensowność użycia słowa kluczowego „replicate” (zidentyfikowanego metodą słownikową) i rzeczownika „replication”. Najmniej przydatne okazuje się słowo „reproduce”, ponieważ częściej jest używane w znaczeniu ponownego zastosowania tej samej praktyki przez organizację, która już ją stosowała.

Sprawdzamy czy nowe słowa kluczowe pozwalają odnaleźć dalsze źródła, powtarzając wcześniejsze wyszukiwanie, ale $\mathrm{z}$ wykorzystaniem poszerzonej listy słów kluczowych.

$\mathrm{TS}=$ (imitation $\mathrm{OR}$ isomorphism $\mathrm{OR}$ emulate $\mathrm{OR}$ mimic $\mathrm{OR}$ mimetic OR replicate OR replication) AND IS=(1941-6520 OR 0363-7425 OR 0149-2063 OR 1086-0266 OR 0001-8392 OR 0272-6963 OR 0047-2506 OR 1460-8545 OR 0001-4273 OR 2327-0608 OR 1523-2409 OR 0031-5826 OR 1094-4281 OR 0964-4733 OR 0261-5177 OR 0022-2380 OR 0017-8012 OR 1048-9843 OR 0143-2095 OR 1535-3958 OR 0048-7333 OR 0305-0483 OR 0166-4972 OR 0960-0035 OR 0021-9010 OR 0008-1256 OR 0894-3796 OR 0019-8501 
OR 1936-9735 OR 0263-7863 OR 1367-3270 OR 0276-7783 OR 1359-8546

OR 0025-1909 OR 0378-7206 OR 0144-3577 OR 2041-3866 OR 1044-5005

OR 0892-9912 OR 0963-8687 OR 0959-6119 OR 0191-3085 OR 1558-9080

OR 2212-571X OR 0737-6782 OR 1469-1930 OR 0266-2426 OR 1053-4822

OR 0921-898X OR 1019-6781 OR 0170-8406 OR 0964-8410)

Uzyskujemy 1413 wyników. Jest to stosunkowo duża liczba, tym bardziej że szukaliśmy publikacji jedynie w 55 najczęściej cytowanych pismach z kategorii „management”. Możemy sprawdzić, ile rezultatów otrzymalibyśmy, przeszukując wszystkie pisma z tej kategorii, posługując się wyszukiwaniem:

$\mathrm{TS}=($ imitation $\mathrm{OR}$ isomorphism $\mathrm{OR}$ emulate $\mathrm{OR}$ mimic $\mathrm{OR}$ mimetic $\mathrm{OR}$ replicate $\mathrm{OR}$ replication) $\mathrm{AND} \mathrm{WC}=($ management $)$

Uzyskujemy 5648 rezultatów. Ta liczba wskazuje, że: a) zjawisko imitacji jest prawdopodobnie częstym tematem badań (dobra wiadomość) oraz b) być może zbyt szeroko zdefiniowaliśmy kryteria wyszukiwania (zła wiadomość).

W kolejnym kroku możemy przeanalizować, które ze słów kluczowych odpowiada za tak duży przyrost rezultatów i czy na pewno jest ono potrzebne. Analiza wskazuje, że za dramatyczny przyrost liczby wyników odpowiadają dwa ostatnie słowa kluczowe, czyli „replicate” oraz „replication” (tabela 1).

Tabela 1. Liczba rezultatów dla każdego ze słów kluczowych-kandydatów

\begin{tabular}{|c|c|c|}
\hline Słowo kluczowe & $\begin{array}{l}\text { Liczba rezultatów } \\
\text { w Q1 management }\end{array}$ & $\begin{array}{c}\text { Liczba rezultatów } \\
\text { w calej kategorii management }\end{array}$ \\
\hline Isomorphism & 275 & 799 \\
\hline Emulate & 52 & 390 \\
\hline Mimetic & 84 & 221 \\
\hline Mimic & 59 & 582 \\
\hline Replicate & 447 & 1822 \\
\hline Replication & 367 & 1398 \\
\hline
\end{tabular}

W kolejnym kroku sprawdzamy w jakim stopniu poszczególne słowa kluczowe są związane z oryginalnym słowem kluczowym, tj. ,imitation”. Naszym celem jest odnalezienie takich słów, które pozwalają odnaleźć nowe wyniki, ale które znaczeniowo lokują się blisko wyjściowego słowa kluczowego. 
Tabela 2. Liczba tekstów zawierających oryginalne słowo kluczowe i nowe słowo kluczowe

\begin{tabular}{|l|r|r|r|c|}
\hline \multicolumn{2}{|c}{ TS=(imitation AND... } & \multicolumn{2}{c}{ Liczba rezultatów w Q1 } & $\begin{array}{c}\text { Liczba rezultatów w całej } \\
\text { kategorii ,management” }\end{array}$ \\
\hline isomorphism) & 34 & $11 \%$ & 73 & $1 \%$ \\
\hline emulate) & 3 & $1 \%$ & 8 & $0 \%$ \\
\hline mimetic) & 20 & $7 \%$ & 36 & $1 \%$ \\
\hline mimic) & 7 & $2 \%$ & 12 & $0 \%$ \\
\hline replicate) & 3 & $1 \%$ & 13 & $0 \%$ \\
\hline replication) & 14 & $5 \%$ & 31 & $1 \%$ \\
\hline
\end{tabular}

Jak widać, dwa ze słów kluczowych (,isomorphism”, „mimetic”) są znacznie silniej związane z oryginalnym słowem kluczowym (,imitation”) niż pozostałe (tabela 2). Na granicy między silnym a słabym związkiem znajduje się słowo „replication”. Musimy mu się bliżej przyjrzeć, by zadecydować czy powinno znaleźć się w końcowym wyszukiwaniu. Analiza tekstów, w których zostało one użyte wskazuje, że pojawia się ono głównie w sekcji „Limitations and further research”, gdzie autorzy stwierdzają, że raportowane badanie powinno zostać zreplikowane. Innymi słowy, najczęściej jest wykorzystywane w znaczeniu innym niż to, które jest obiektem naszego zainteresowania. Na tej podstawie możemy podjąć decyzję, by ograniczyć nasze słowa kluczowe do następującej listy: imitation, isomorphism i mimetic. Nasz ciąg wyszukiwawczy wyglądałby zatem następująco:

$\mathrm{TS}=($ imitation $\mathrm{OR}$ isomorphism $\mathrm{OR}$ mimetic $)$ AND $\mathrm{WC}=($ management $)$

Wyszukanie oparte na tych słowach kluczowych daje 577 wyników w pismach Q1, natomiast we wszystkich periodykach z kategorii „management” uzyskujemy 1744 rezultaty. Uzyskaliśmy liczbę rezultatów, które można przeanalizować i jednocześnie na tyle dużą, że może ona być uznana za kompletną. Pamiętajmy, że ta liczba zostanie zmniejszona w kolejnych etapach formułowania kryteriów wyszukiwania.

Przykład 2. Cyberloafing. W związku z tym, że „cyberloafing” nie posiada żadnych synonimów (sprawdziliśmy to metodą słownikową) przystępujemy od razu do poszukiwania słów kluczowych na podstawie analizy wcześniejszej literatury. Jednak postępujemy inaczej niż w poprzednim przykładzie. Cyberloafing to zjawisko, które trudno jednoznacznie zakwalifikować do nauk o zarządzaniu. Może być także przedmiotem badań psychologów, jak i osób zajmujących się bezpieczeństwem systemów komputerowych. Zarazem, wydaje się, że to słowo 
nie jest często stosowane w języku potocznym. Dlatego nie ograniczamy wstępnego wyszukiwania do Q1 WoS ani nawet do jakiejkolwiek kategorii tematycznej WoS i poszukujemy wszystkich publikacji, w których występuje to słowo kluczowe:

$$
\mathrm{TS}=(\text { cyberloafing })
$$

Uzyskujemy 108 rezultatów. Następnie postępujemy, tak jak w przykładzie 1: sortujemy po liczbie cytowań i dacie publikacji, uzyskujemy 20 tekstów do przejrzenia w poszukiwaniu synonimów pojęcia „cyberloafing”. Odkrywamy nowe słowa kluczowe, za pomocą których nazywany jest ten sam lub podobne konstrukty.

Jednocześnie zauważamy, że w pierwszej dekadzie upowszechniania się Internetu (1995-2004) opublikowano zaledwie dwa teksty posługujące się słowem „cyberloafing”: artykuł, w którym to pojęcie zostało zdefiniowane (Lim, 2002) oraz jeden list do redakcji pisma (Polito, 1997) (wykres $1^{2}$ ). Każe nam to podejrzewać, że w tym okresie - przed zdefiniowaniem pojęcia przez Vivien Lim - autorzy posługiwali się innymi słowami kluczowymi. W celu ich odnalezienia czytamy tekst Lim i poszukujemy odwołań literaturowych, które wykorzystała w swoim tekście - zakładamy, że autorka musiała powoływać się na wcześniejszą literaturę poświęconą temu zagadnieniu.

\section{Rysunek 2. Liczba publikacji ze słowem „cyberloafing”}

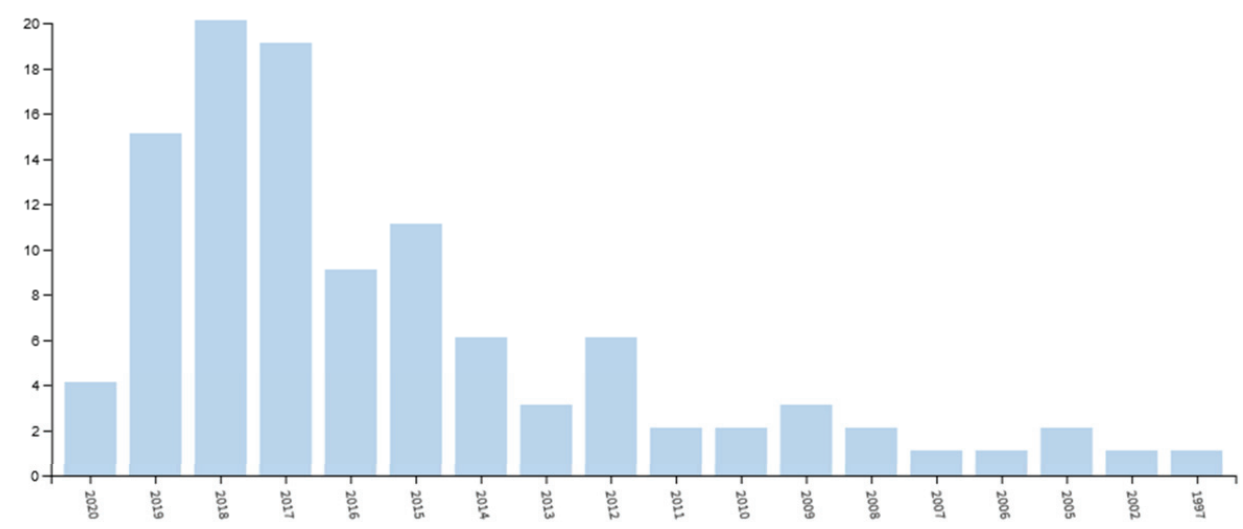

2 Wykres pokazujący częstość publikacji w czasie uzyskujemy, klikając na pierwszej stronie rezultatów wyszukiwania „Analyze Results” (prawy górny róg strony), a następnie wybierając „Publication Years”. 
W rezultacie tych działań otrzymujemy listę nowych słów kluczowych: „cyberslacking”, „cyberdeviance”, „,yber deviance”, „non-work-related computing”, „workplace Internet leisure browsing”, „Internet abuse”, “workplace internet deviance", "personal use of the Internet". Na tej podstawie konstruujemy wstępne zapytanie do bazy:

$\mathrm{TS}=$ (cyberloafing OR cyberslacking OR cyberdeviance OR "cyber deviance" OR "non-work-related computing" OR "workplace Internet leisure browsing" OR "Internet abuse" OR "workplace internet deviance" OR "personal use of the Internet")

UWAGA: wiele edytorów tekstu, w tym MS Word, podczas wpisywania tekstu zamienia górne cudzysłowy na dolne, czyli ciąg znaków "cyber deviance" zostaje zamieniony na „cyber deviance”. Dolny cudzysłów jest niezrozumiały dla Web of Science więc sygnalizuje błąd ciągu wyszukiwawczego. Niestety, jeśli w ciągu wyszukiwania znajdują się również frazy, które zwrócą jakiś wynik (np. TS=(cyberloafing OR „cyber deviance”)), to WoS nie poinformuje nas o błędzie i wyświetli wynik. W rezultacie uzyskamy liczbę wyników, ale będzie ona błędna - co gorsza, nie będziemy o tym wiedzieli. Dlatego należy zwracać szczególną uwagę na cudzysłowy w wyszukiwaniach, a sam ciąg wyszukiwania najlepiej przygotowywać w innym edytorze tekstów (np. darmowym Notepad ++).

Uzyskaliśmy 252 rezultaty, w tym 23 nowe publikacje dla dekady 1995-2004, co potwierdza naszą intuicję mówiącą, że w pierwszym okresie upowszechniania Internetu posługiwano się innymi pojęciami. Analiza liczby wyników dla poszczególnych słów kluczowych oraz ich współwystępowania wskaże, że niektóre słowa kluczowe nie pozwalają zidentyfikować nowych tekstów. Przykładowo, słowo kluczowe „cyberdeviance” (pisane razem) pozwala odnaleźć tylko dwie publikacje i to takie, w których również użyto pojęcia „cyberloafing.” Zatem to słowo nie przynosi żadnej wartości dodanej. Niemniej, wziąwszy pod uwagę stosunkowo niewielką liczbę wyników uzyskanych w wyszukiwaniu (252), lepiej jest to słowo zostawić w ciągu wyszukiwania. Przygotowanie systematycznego przeglądu literatury może zająć miesiące, a nawet lata. Niewykluczone, że tuż przed zakończeniem pracy będziemy musieli sporządzić aktualizację przeglądu. Wtedy może się okazać, że to nadmiarowe słowo kluczowe pozwoli nam odnaleźć nowo opublikowany tekst.

\subsubsection{Pozostałe kryteria}

Zakres systematycznego przeglądu literatury można ograniczać poprzez określanie kryteriów wykraczających poza badane konstrukty/zmienne. Te dodatkowe 
ograniczenia muszą zawsze być uzasadnione merytorycznie. Innymi słowy, nie możemy wprowadzać dodatkowych kryteriów tylko dlatego, że odnaleźliśmy bardzo dużo tekstów, które trudno będzie nam przeczytać i zagregować.

Pierwsza kategoria takich kryteriów to typ badanej jednostki. Wprowadzenia takiego kryterium musi być uzasadnione teoretycznie. Przykładowo, ograniczamy wyszukiwanie tylko do badań przeprowadzonych w administracji publicznej i sektorze publicznym, ponieważ dotychczasowe badania wskazują, że interesujące nas zjawisko kształtuje się inaczej w tym sektorze niż w przedsiębiorstwach komercyjnych. Do kryteriów dotyczących badanej jednostki zaliczamy:

- sektor (np. przedsiębiorstwa prywatne, administracja publiczna),

- branżę/typ organizacji (np. przemysł motoryzacyjny, przedsiębiorstwa ponadnarodowe, organizacje społeczne),

- jednostkę - uczestnik badania (np. pracownicy sprzedaży, studenci, menedżerowie).

Pamiętajmy, że uzasadnienie włączenia takiego kryterium musi być oparte na żelaznych podstawach teoretycznych: recenzenci w pierwszej kolejności zakwestionują właśnie ten element ciągu wyszukiwawczego.

W niektórych wypadkach wprowadzane są ograniczenia dotyczące typu badania (ilościowe, jakościowe, eksperymentalne, obserwacyjne), jednak jest to praktyka wątpliwa i również musi być wynikać z mocnego uzasadnienia teoretycznego. Jedną z podstawowych zalet SPL (w porównaniu z metaanalizą) ma być możliwość uwzględnienia studiów dowolnego rodzaju. Jeśli chcielibyśmy ograniczyć przegląd do badań ilościowych, to lepiej jest się zdecydować na sporządzenie klasycznej metaanalizy.

Ostatnim kryterium jest przedział czasu, dla którego będziemy poszukiwać badań. Ograniczenie przeszukiwanego zakresu czasowego jest najczęściej uzasadniane dwiema przesłankami. Po pierwsze, ograniczamy zakres czasowy, gdy istnieje już systematyczny przegląd literatury na interesujący nas temat. Przykładowo, w 2017 roku ukazała się metaanaliza na temat cyberloafingu oparta na badaniach opublikowanych do 2015 roku (Mercado, Giordano i Dilchert, 2017). W takiej sytuacji możemy jako punkt początkowy zakresu wyznaczyć rok 2016.

Po drugie, możemy uznać, że postęp w metodach badawczych i/lub zmiana w badanym wycinku rzeczywistości są na tyle duże, że najwcześniejsze publikacje cechują się niską trafnością i/lub opisują rzeczywistość na tyle różną od stanu obecnego, że ich uwzględnianie w SPL jest nieuzasadnione. Przykładowo, prawdopodobnie w roku 2040 autorzy systematycznych przeglądów literatury na temat cyberloafingu nie będą uwzględniać badań powstałych w okresie 1995-2010, ponieważ sposoby korzystania z Internetu i sposoby pracy zmienią się na tyle, że te wcześniejsze badania nie będą już relewantne. Ponadto, wykorzystanie big data w nowszych badaniach zapewne sprawi, że wyniki uzyskane wcześniej nie będą wystarczająco trafne (patrz sekcja 5.4), by z nich korzystać. 


\subsection{Kryteria dotyczące źródeł}

\subsubsection{Biała i szara literatura}

Idea systematycznego przeglądu literatury oparta jest na założeniu, że najlepszą wiedzę o badanym zjawisku uzyskamy, analizując wszystkie wyniki badań, bez względu na miejsce i formę publikacji. Gdyby trzymać się tego założenia, kryteria dotyczące źródeł nie powinny być stosowane. Powinniśmy przeszukiwać wszystkie typy publikacji:

- „białą” literaturę (white literature), tj. artykuły opublikowane w recenzowanych pismach naukowych;

- „szarą” literaturę (Adams, Smart i Huff, 2017):

a) pierwszej kategorii (1st tier grey literature): książki, rozdziały w książkach, raporty rządowe, publikacje think tanków;

b) drugiej kategorii (2nd tier grey literature): raporty roczne, artykuły prasowe, nagrania wideo, prezentacje, publikacje wydawane przez przedsiębiorstwa, raporty NGO, artykuły w Wikipedii, reklamy;

c) trzeciej kategorii (3rd tier grey literature): blogi, emaile, tweety, listy, katalogi.

Jednak to zalecenie metodyczne jest często łamane przez autorów systematycznych przeglądów literatury w naukach o zarządzaniu. Analiza SPL opublikowanych w okresie 2003-2014 przez naukowców (124 przeglądy) i praktyków (16 przeglądów) ujawnia, że 69\% SPL nie uwzględnia „szarej” literatury (Adams i in., 2017) - czy to pomijając milczeniem tę kwestię (46\%), czy to stwierdzając, że „szarą" literaturę odnaleziono, lecz była zbyt niskiej jakości by ją wykorzystać $(22 \%)$. Jeśli zawęzić analizę tylko do SPL sporządzonych przez naukowców, to udział przeglądów, które pomijają „szarą” literaturę rośnie do 77\%. Pewna część autorów SPL idzie dalej i ogranicza swoje poszukiwania tylko do wybranych pism naukowych.

Zatem ogólna tendencja jest taka, by odchodzić od oryginalnych założeń metodycznych SPL. Można sądzić, że to zjawisko jest spowodowane dwiema przyczynami: ilością literatury oraz przekonaniem, że tylko to, co opublikowano w recenzowanych pismach (najlepiej o najwyższym impact factor) charakteryzuje się wystarczającą jakością. Obie przesłanki można uznać za wątpliwe, jednak wydaje się, że mimo to kształtują one publikowane przeglądy literatury.

Adams i in. (2017) sugerują, by w przypadku dobrze rozwiniętych i dojrzałych tematów badawczych ograniczać się do przeszukiwania pism naukowych oraz ewentualnie „,szarej” literatury pierwszej kategorii. W przypadku gdy „szara” literatura może dostarczyć ciekawych rezultatów, ale jest jej zbyt dużo do przeanalizowania, wspomniani autorzy zalecają przeprowadzenie badania pilotażowego takiej literatury lub ograniczenie zakresu badania (modyfikacja tematu SPL). 


\subsubsection{Lista periodyków naukowych}

Jak wspomniałem, część przeglądów literatury ogranicza przeszukiwanie do pewnej listy pism. Takie posunięcie opiera się na założeniu, że debata naukowa dotycząca danego zagadnienia toczy się przede wszystkim na łamach pism zakwalifikowanych do tej listy i nie ma potrzeby przeszukiwania innych źródeł. Jest to rozwiązanie niezwykle wygodne z punkty widzenia autorów SPL, jednak wiąże się z licznymi zagrożeniami.

Po pierwsze, dokonanie właściwego doboru pism do listy wymaga bardzo dobrej znajomości tematyki, której ma dotyczyć planowany SPL. Taka znajomość przeważnie wynika z prowadzenia badań związanych z tematem, co wymaga stałego śledzenia nowych publikacji poświęconych danemu zagadnieniu oraz z uczestniczenia w konferencjach. Nawet w takiej sytuacji istnieje ryzyko przeoczenia ważnego periodyku, który powinien być uwzględniony w przeglądzie.

Po drugie, konieczna jest bardzo dobra znajomość przekonań środowiska naukowego zajmującego się daną tematyką. Często popełniany błąd polega na utożsamianiu wysokości współczynnika impact factor z prestiżem periodyku naukowego. Ranking prestiżu pism naukowych rządzi się znacznie bardziej złożonymi regułami. Pisma o bardzo wysokim impact factor są w pewnych środowiskach uznawane za periodyki drugiej kategorii, podczas gdy inne - o stosunkowo niskim IF - są uznawane za wartościowe. Prestiż bowiem wynika nie z IF, lecz ze składu osobowego redakcji i listy autorów publikujących w danym piśmie. Nawiasem, gdy naukowcy oświadczają, że w ocenie publikacji nie należy kierować się wskaźnikami IF czy rankingami pism (np. Financial Times 50 czy UT Dallas ranking), w rzeczywistości na ogół mają na myśli, że należy się kierować rankingami, tyle że tymi, które w sposób nieformalny zostały ustalone przez środowisko naukowe, do którego dany naukowiec należy. Zatem na autorów SPL czyha pułapka - jeśli w wyniku braku wyczucia mody panującej w środowisku pominą najważniejsze periodyki, to recenzenci nie pozostawią na przeglądzie suchej nitki.

Po trzecie, ograniczanie przeszukiwania do z góry określonej listy pism może obniżyć jakość merytoryczną przeglądu. Niewykluczone, że wszyscy autorzy publikujący w tych pismach przyjmują takie same założenia co do natury badanego problemu, co prowadzi ich do tych samych wyjaśnień. Można powiedzieć, że badacze działający w ramach pewnego środowiska naukowego funkcjonują wewnątrz bańki informacyjnej - wzajemnie potwierdzają swoje poglądy i wyniki, nigdy zaś nie docierają do nich informacje z zewnątrz. Jeśli zatem ograniczymy nasz przegląd do pism nalężących do tej „bańki”, nigdy nie trafimy na wyniki, które kwestionowałyby założenia podzielane przez naukowców zamkniętych w bańce. W rezultacie nasz przegląd literatury zakończymy jednoznacznymi wnioskami o istnieniu/nieistnieniu pewnej zależności, podczas gdy uwzględnie- 
nie badań z innych środowisk, które przyjmują inne założenia, skłoniłoby by nas do sformułowania bardziej zniuansowanych konkluzji.

\subsubsection{Typ publikacji}

Celem sporządzania systematycznego przeglądu literatury jest na ogół integracja wyników empirycznych. W większości przypadków ograniczamy zatem nasze wyszukiwanie do publikacji, w których zawarto wyniki badań. Innymi słowy, pomijamy inne typy publikacji, to jest przede wszystkim opracowania teoretyczne.

Od tej ogólnej reguły można zrobić wyjątek. Nic nie stoi na przeszkodzie by celem SPL była agregacja podejść teoretycznych. W takiej sytuacji wyszukujemy wyłącznie publikacje teoretyczne. Celem SPL może być też sporządzenie konceptualnej mapy danego tematu badawczego (jakie teorie są stosowane, jakie konstrukty są wybierane jako zmienne niezależne i kontrolne, jak się je operacjonalizuje itd.). W takiej sytuacji w SPL uwzględniamy zarówno wyniki empiryczne, jak i prace teoretyczne.

Jednak oryginalna koncepcja systematycznego przeglądu literatury nakazywała bazowanie jedynie na wynikach empirycznych. Niestety, na etapie wyszukiwania artykułów w bazach danych trudno jest wyłączyć teksty teoretyczne. Eliminacja artykułów innych niż empiryczne odbędzie się dopiero w czwartym etapie procedury, tj. przy analizie odnalezionych tekstów na podstawie tytułów i abstraktów. Można w pewnym stopniu ograniczyć liczbę wyników, posługując się poleceniem Document Type (DT) do wyłączenia typów publikacji, o których z pewnością wiemy, że nie zawierają rezultatów badań empirycznych: recenzji książek, tekstów od redakcji czy wpisów biograficznych. Przykładowo, ograniczenie ciągu wyszukiwawczego sformułowanego w sekcji 2.1.1.2 wyglądałoby tak:

$\mathrm{TS}=($ imitation $\mathrm{OR}$ isomorphism $\mathrm{OR}$ mimetic) $\mathrm{AND} \mathrm{WC}=($ management $)$ NOT DT $=($ Book Review OR Editorial Material OR Discussion OR Letter OR Meeting Abstract OR Meeting Summary)

W rezultacie uzyskujemy 1708 zamiast 1744 publikacji. Pamiętajmy przy tym, że nie można wyszukiwania ograniczać jedynie do typu dokumentu „Article”. Takie ograniczenie sprawi, że nie znajdziemy informacji o wycofaniu tekstu („retraction”) oraz samych wycofanych tekstów (,retracted”). To zaś spowoduje, że w naszym SPL będziemy omawiać badania, które zostały wycofane z druku ze względu na błędy lub nadużycia etyczne. Ponadto, jak już wcześniej wspomniałem, posługiwanie się wszelkimi kategoryzacjami Web of Science czy redakcji czasopism naraża nas na popełnienie błędu, ponieważ takie kategoryzacje nie zawsze są trafne. Tego rodzaju błąd będzie miał mniejsze znaczenie, 
gdy spowoduje zakwalifikowanie do rezultatów publikacji, która nie powinna się wśród nich znaleźć. $\mathrm{Z}$ większym problemem będziemy mieli do czynienia, gdy w wynikach nie znajdzie się publikacja, która powinna się wśród nich znaleźć.

\subsubsection{Język publikacji}

W światowych pismach naukowych przyjmuje się na ogół, że analizie poddajemy jedynie teksty w języku angielskim. Tej praktyki należy się trzymać w przypadku SPL przygotowywanych z myślą o publikacji w piśmie zagranicznym. Przykładowo, ograniczenie ciągu wyszukiwawczego omówionego w sekcji 2.1.1.2 do publikacji w języku angielskim przeprowadzamy w ten sposób:

$\mathrm{TS}=($ imitation $\mathrm{OR}$ isomorphism $\mathrm{OR}$ mimetic) $\mathrm{AND} \mathrm{WC}=($ management $)$ AND LA $=($ English $)$

W rezultacie otrzymujemy 1715 rezultatów zamiast 1740 .

W przypadku SPL przygotowywanych dla polskiego odbiorcy lub mających stanowić podstawę do własnego badania warto uwzględnić również publikacje w języku polskim lub innym języku uzasadnionym tematem badania. Przykładowo, jeśli moim zamiarem jest przeprowadzenie badania porównawczego stosowania metod New Public Management w Polsce, Włoszech i Hiszpanii to warto szukać publikacji w językach angielskim, polskim, włoskim i hiszpańskim.

\subsection{Kryteria dotyczące baz bibliograficznych}

Niezbędnym elementem procesu tworzenia kryteriów wyszukiwania jest określenie baz bibliograficznych, w których będziemy prowadzić poszukiwania oraz pól baz danych, które będziemy przeszukiwać.

\subsubsection{Przeszukiwane bazy}

Celem systematycznego przeglądu literatury jest odnalezienie wszystkich publikacji związanych z tematem przeglądu. W związku z tym, że ludzie popełniają błędy, a każda z baz tylko fragmentarycznie odzwierciedla opublikowane rezultaty, każde wyszukiwanie powinniśmy prowadzić w co najmniej dwóch bazach. W tym skrypcie posługuję się Web of Science oraz Scopus. Można jednak rozważać posługiwanie się również innymi bazami (zob. sekcja 7.2). 


\subsubsection{Przeszukiwane pola bazy}

Bazy bibliograficzne przechowują dane w odrębnych polach (np. tytu1, abstrakt, słowa kluczowe), wynik wyszukiwania zależy więc w decydującym stopniu od wyboru pola/pól, w których będziemy prowadzić wyszukiwanie (charakterystyka pól znajduje się w sekcjach 7.1.1-7.1.2.). W niniejszym skrypcie posługuję się przede wszystkim polem TOPIC (TS) bazy Web of Science, które jest sumą pól TITLE (tytuł), ABSTRACT (streszczenie), AUTHOR KEYWORDS (słowa kluczowe sformułowane przez autorów publikacji) oraz KEYWORDS PLUS (słowa kluczowe dodane przez Web of Science na podstawie analizy tytułu publikacji). Jest to zalecana praktyka, ponieważ przeszukiwanie samego tytułu prawdopodobnie nie pozwoli odnaleźć wszystkich publikacji związanych z tematem (Tabela 3).

Tabela 3. Porównanie liczby rezultatów przeszukiwania pól TITLE i TOPIC

\begin{tabular}{l|l|c|}
\multicolumn{1}{c}{ Przeszukiwane pole } & \multicolumn{1}{c}{ Zapytanie do bazy } & \multicolumn{1}{c|}{$\begin{array}{c}\text { Liczba } \\
\text { rezultatów }\end{array}$} \\
\hline TITLE & $\begin{array}{l}\text { TI=(imitation OR isomorphism OR mimetic) AND } \\
\text { WC=(management) }\end{array}$ & 282 \\
\hline TOPIC & $\begin{array}{l}\text { TS=(imitation OR isomorphism OR mimetic) AND } \\
\text { WC=(management) }\end{array}$ & 1744 \\
\hline
\end{tabular}

\subsubsection{Dodatkowe metody wyszukiwania}

SPL zawsze oparte są na systematycznym wyszukiwaniu w bazach bibliograficznych. Jednak w wielu przypadkach dodatkowo stosowana jest również metoda kuli śniegowej — po odnalezieniu wyników w bazie bibliograficznej autorzy SPL przeglądają bibliografie odnalezionych tekstów w poszukiwaniu źródeł, których nie zostały znalezione w bazach, a które powinny być omówione w SPL (zob. przykład z poszukiwaniem synonimów dla „cyberloafingu” przedstawiony w sekcji 2.1.1.2). W ten sposób udaje się znaleźć monografie i rozdziały w monografiach, publikacje z innych dyscyplin, ,szarą” literaturę (np. raporty opracowane przez agendy rządowe), jak również artykuły naukowe, które nie zostały prawidłowo opisane w bazach bibliograficznych (np. nie wprowadzono treści abstraktu). 


\section{Rozdział 3}

\section{Wyszukiwanie}

Na podstawie kryteriów opracowanych w drugim etapie analizy konstruujemy finalny ciąg wyszukiwania, który posłuży nam do odnalezienia publikacji do przeglądu. Przygotowując kryteria wyszukiwania i formułując ostateczną kwerendę, kierujemy się zasadą mówiącą, że lepiej jest znaleźć zbyt dużo źródeł, niż zbyt mało. Stosowanie się do tej zasady oznacza, że w kolejnym, tj. czwartym, etapie procedury włożymy sporo wysiłku w lekturę tytułów i abstraktów tekstów, które następnie odrzucimy. Jest to niestety niezbędny koszt sporządzania SPL. Tabela 1 zawiera przegląd przykładów przedstawionych w tym rozdziale, wskazując ich specyfikę.

Tabela 1. Przykłady omówione w rozdziale

\begin{tabular}{|c|c|c|c|}
\hline Przykład & Treść & $\begin{array}{c}\text { Liczba } \\
\text { rezultatów } \\
\text { początkowego } \\
\text { wyszukiwania }\end{array}$ & $\begin{array}{c}\text { Liczba } \\
\text { rezultatów } \\
\text { końcowego } \\
\text { wyszukiwania }\end{array}$ \\
\hline Protoinstytucje & $\begin{array}{l}\text { przykład pokazuje, w jaki sposób wykorzystać SPL } \\
\text { jako podstawę badania własnego; wyszukiwanie } \\
\text { zawężone do artykułów naukowych i dyscypliny } \\
\text { (zarządzanie i pokrewne) }\end{array}$ & 13432 & 768 \\
\hline Imitacja & $\begin{array}{l}\text { przykład pokazuje, jak zawęzić zakres } \\
\text { wyszukiwania do listy pism, jednocześnie } \\
\text { podkreślając ryzyko z tym związane }\end{array}$ & 2424 & 554 \\
\hline Cyberloafing & $\begin{array}{l}\text { przykład, w którym wyszukiwanie nie zostało } \\
\text { zawężone do dziedziny i nie zostało zawężone } \\
\text { do artykułów naukowych ze względu na } \\
\text { tematykę SPL (styk zarządzania i informatyki } \\
\text { - wyszukiwanie obejmuje również publikacje } \\
\text { konferencyjne) }\end{array}$ & 252 & 236 \\
\hline Outsourcing & $\begin{array}{l}\text { wyszukiwanie nie ograniczone do dyscypliny } \\
\text { „zarządzanie”, publikacje związane z tematem } \\
\text { przeglądu ukazują się bowiem w ekonomii, IT, } \\
\text { badaniach służby zdrowia, administracji publicznej } \\
\text { itd.; ponieważ istnieje wcześniejszy SPL, } \\
\text { wyszukiwanie ograniczono do publikacji } \\
\text { z lat 2013-2020 }\end{array}$ & 3668 & 1677 \\
\hline
\end{tabular}




\subsection{Przykład 1. Temat SPL: protoinstutucje}

We wstępnym rozpoznaniu badań nad protoinstytucjami odkryliśmy, że studiów poświęconych temu zagadnieniu jest niewiele. Jeśli ograniczymy się jedynie do artykułów, które używają tego słowa kluczowego $(\mathrm{TS}=($ proto-institution)) to otrzymamy zaledwie 13 rezultatów - liczbę zbyt małą by sporządzić SPL. $\mathrm{Na}$ tej podstawie powinniśmy podjąć decyzję o zaniechaniu dalszych prac nad SPL - warunkiem wstępnym przeprowadzenia systematycznego przeglądu literatury jest bowiem pewna podstawowa chociaż dojrzałość temat badawczego. Jeśli jednak posługujemy się metodą SPL by przygotować bazę literaturową dla własnego badania, możemy kontynuować pracę. Zakładamy, że dla badań nad protoinstytucjami ważne będą wszystkie publikacje omawiające proces instytucjonalizacji (protoinstytucje, to instytucje, które znajdują się na początku tego procesu). Zatem rozpoczynamy tworzenie ciągu wyszukiwawczego od następującego sformułowania:

$\mathrm{TS}=($ proto-institution OR institutionali?ation $\$)$

Otrzymujemy 13432 wyników. Liczba ta jest tak duża, ponieważ słowo „,institutionalization" jest wykorzystywane w wielu różnych znaczeniach w różnych dyscyplinach (np. w medycynie może oznaczać skierowanie pacjenta do szpitala psychiatrycznego). Ograniczamy zakres wyszukiwania do trzech kategorii Web of Science: „management”, „business” oraz „business, finance”:

$\mathrm{TS}=($ proto-institution $\mathrm{OR}$ institutionali $?$ ation $\$) \mathrm{AND} \mathrm{WC}=($ management OR business OR business, finance)

Uzyskujemy 1083 rezultaty. Eliminujemy z wyszukiwania publikacje, które nie zawierają wyników badań empirycznych:

$\mathrm{TS}=($ proto-institution $\mathrm{OR}$ institutionali?ation $\$)$ AND $\mathrm{WC}=($ management OR business OR business, finance) NOT DT $=($ Book Review OR Editorial Material OR Discussion OR Letter OR Meeting Abstract OR Meeting Summary)

Liczba tekstów została ograniczona do 1065 . Wprowadzamy dalsze ograniczenie - poszukujemy tylko publikacji, które ukazały się w języku angielskim:

$\mathrm{TS}=($ proto-institution $\mathrm{OR}$ institutionali?ation\$) AND $\mathrm{WC}=$ (management OR business OR business, finance) NOT DT $=($ Book Review OR Editorial 
Material OR Discussion OR Letter OR Meeting Abstract OR Meeting Summary) AND LA=(English)

Uzyskaliśmy 1024 publikacje. Inspekcja wyników wskazuje, że wyszukiwanie odnalazło 13 artykułów opublikowanych w Academy of Management Review, piśmie, które publikuje wyłącznie teksty teoretyczne. Jeśli naszym celem jest sporządzenie SPL sumującego wyniki empiryczne, to wyłączamy to pismo, dodając do ciągu wyszukiwania NOT IS=(0363-7425 OR 1930-3807). Jeśli zaś celem jest całkowite rozpoznanie tematu lub stworzenie konceptualnej mapy badań and protoinstytucjami, rozpoczynamy lekturę odnalezionych tekstów właśnie od artykułów z Academy of Management Review, ponieważ dzięki nim dowiemy się bardzo wiele o podejściach teoretycznych stosowanych do opisu procesu instytucjonalizacji.

Jeśli chcemy dalej ograniczyć nasze wyszukiwanie tak, aby uwzględniało wyłącznie publikacje, które okazały się jako artykuły naukowe, możemy poszerzyć listę wykluczonych typów publikacji w polu DT:

$\mathrm{TS}=($ proto-institution $\mathrm{OR}$ institutionali?ation\$) AND $\mathrm{WC}=($ management OR business OR business, finance) NOT DT=(Book Review OR Editorial Material OR Discussion OR Letter OR Meeting Abstract OR Meeting Summary OR Review OR Proceedings Paper OR Book Chapter OR Book) AND LA $=($ English $)$

Odnaleźliśmy 768 artykułów naukowych, które będą stanowić podstawę przeglądu literaturowego do badania empirycznego.

\subsection{Przykład 2. Temat SPL: Imitacja}

Podczas poszukiwania synonimów do pojęcia „imitation” (sekcja 2.1.1.1-2) ustaliśmy, że początkowy ciąg ( $\mathrm{TS}=($ imitation OR isomorphism OR mimetic) AND $\mathrm{WC}=($ management $)$ ) pozwala odnaleźć 1744 publikacje. Jest to liczba tekstów zdecydowanie wystarczająca do przeprowadzenia SPL. Analogicznie do przykładu pierwszego, rozszerzamy zakres wyszukiwania poprzez dodanie kategorii „business” i ,business, finance”:

$\mathrm{TS}=($ imitation $\mathrm{OR}$ isomorphism OR mimetic) $\mathrm{AND} \mathrm{WC}=($ management $\mathrm{OR}$ business OR business, finance)

Uzyskujemy 2424 rezultaty. Eliminujemy z wyszukiwania publikacje, które nie zawierają wyników badań empirycznych: 
$\mathrm{TS}=$ (imitation $\mathrm{OR}$ isomorphism $\mathrm{OR}$ mimetic) $\mathrm{AND} \mathrm{WC}=$ (management $\mathrm{OR}$ business OR business, finance) NOT DT $=($ Book Review OR Editorial Material OR Discussion OR Letter OR Meeting Abstract OR Meeting Summary) skim:

Otrzymaliśmy 2370 wyników. Ograniczamy do publikacji w języku angiel-

$\mathrm{TS}=$ (imitation $\mathrm{OR}$ isomorphism $\mathrm{OR}$ mimetic) $\mathrm{AND} \mathrm{WC}=$ (management OR business OR business, finance) NOT DT $=$ (Book Review OR Editorial Material OR Discussion OR Letter OR Meeting Abstract OR Meeting Summary) AND LA=(English)

Wyszukiwanie daje 2320 rezultatów. W związku z tym, że naszym celem jest przygotowanie SPL (a nie podstawy do własnego badania, jak w przykładzie 1), możemy wyłączyć wszystkie publikacje, które nie zawierają wyników badań empirycznych. Dokonujemy tego, dodając do listy wykluczeń typ dokumentu (DT) „Review” oraz pismo Academy of Management Review, które publikuje wyłącznie teksty teoretyczne:

$\mathrm{TS}=($ imitation $\mathrm{OR}$ isomorphism $\mathrm{OR}$ mimetic) $\mathrm{AND} \mathrm{WC}=($ management OR business OR business, finance) NOT DT $=($ Book Review OR Editorial Material OR Discussion OR Letter OR Meeting Abstract OR Meeting Summary OR Review) AND LA=(English) NOT IS=(0363-7425 OR 1930-3807)

Uzyskaliśmy 2192 rezultaty, które powinny stać się podstawą systematycznego przeglądu literatury. Jest to jednak liczba dość duża, należałoby więc, zgodnie z zaleceniami przedstawionymi w rozdziale 2, ograniczyć zakres tematyczny poprzez wybór tylko jednego aspektu procesu imitacji, co pozwoli dodać kolejne słowa kluczowe ograniczające liczbę odnalezionych tekstów.

Jeśli jednak chcemy sporządzić przegląd na temat wyznaczony wcześniej, to dalsze zmniejszanie liczby publikacji wymaga podejmowania decyzji o rosnącym stopniu ryzyka (ponieważ recenzenci mogą je łatwo zakwestionować). Pierwsza decyzja polegałaby na ograniczeniu wyszukiwania jedynie do artykułów naukowych. Jest to powszechna praktyka w naukach o zarządzaniu (Adams i in., 2017), dlatego ryzyko zakwestionowania tej decyzji nie jest bardzo wysokie.

$\mathrm{TS}=($ imitation $\mathrm{OR}$ isomorphism $\mathrm{OR}$ mimetic $)$ AND WC $=($ management $\mathrm{OR}$ business OR business, finance) $A N D D T=($ Article OR Early Access OR Correction OR Retracted Publication $)$ AND LA $=($ English $)$ NOT IS $=(0363-$ 7425 OR 1930-3807) 
Otrzymaliśmy 1861 wyników. Kolejne posunięcie jest znacznie bardziej ryzykowne - spróbujemy ograniczyć wyszukiwanie do pism, które są uznawane za dobre przez środowisko instytucjonalistów pracujących w dyscyplinie nauki o zarządzaniu i jakości. Jest to decyzja ryzykowna, ponieważ zależy od naszego wyczucia nastrojów panujących w tym środowisku.

Do sporządzenia listy czasopism możemy zabrać się na dwa sposoby. Po pierwsze, możemy stworzyć taką listę a priori, posługując się naszą wiedzą. Po drugie możemy wejść w wyniki w Web of Science, kliknąć „Analyze Results” i na następnej stronie wybrać „Source Titles” (rysunek 1). Następnie zwiększamy liczbę pól widocznych jednocześnie na stronie (ramka „Show”) do 500 i klikamy „Update”. Na liście wybieramy pisma, które uznajemy za właściwe dla naszego tematu badawczego.

\section{Rysunek 1. Wybór pism}

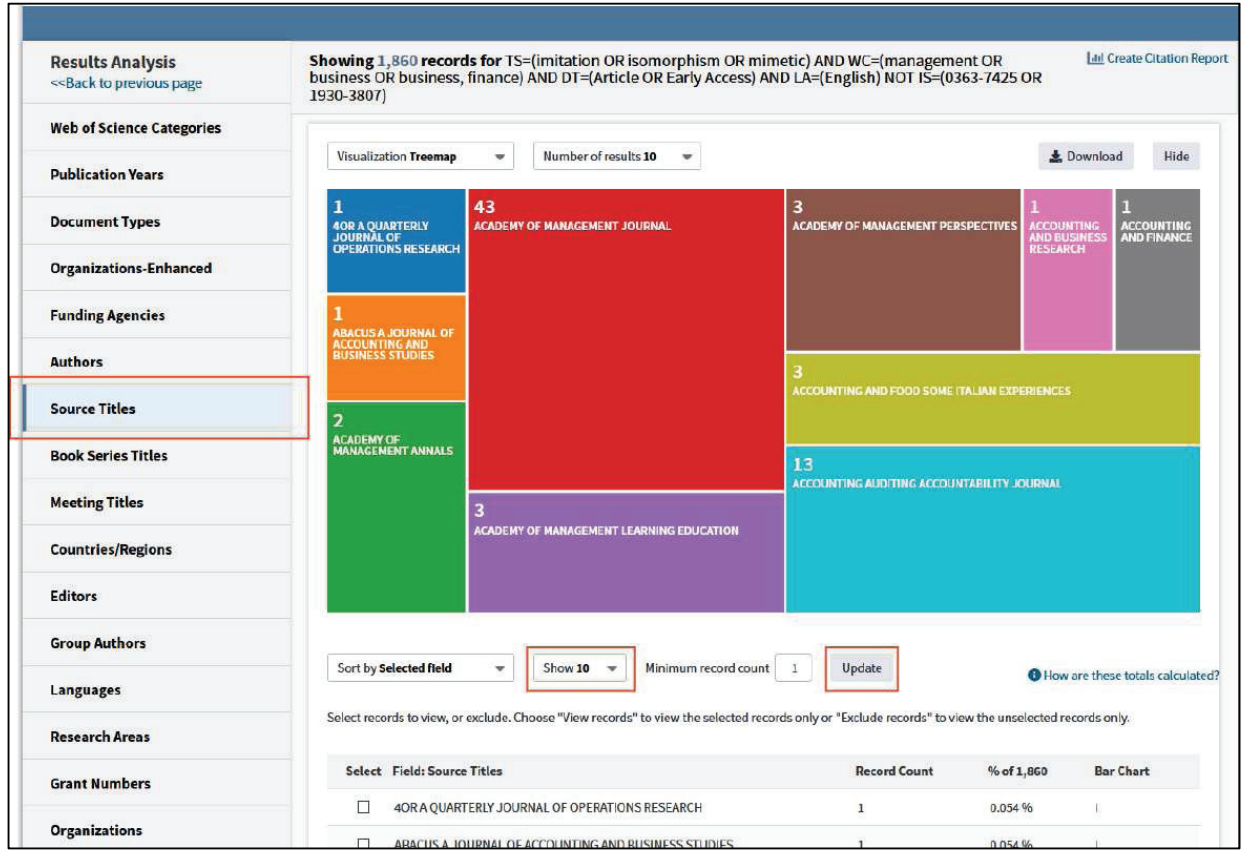

W rezultacie otrzymujemy poniższy ciąg wyszukiwania. Proszę zwrócić uwagę, że z zapytania wyeliminowałem polecenie mające wyłączyć artykuły opublikowane w Academy of Management Review (NOT IS=(0363-7425 OR 1930-3807)) - nie jest już potrzebne ponieważ wyszukiwanie jest prowadzone tylko w pismach wymienionych w nawiasie zaznaczonym kolorem czerwonym. 
$\mathrm{Z}$ tego samego powodu usunąłem ograniczenie dotyczące przeszukiwanych dyscyplin $(\mathrm{WC}=($ management $\mathrm{OR}$ business $\mathrm{OR}$ business, finance $)$ ).

$\mathrm{TS}=($ imitation $\mathrm{OR}$ isomorphism OR mimetic $)$ AND DT $=($ Article OR Early Access OR Correction OR Retracted Publication) AND LA=(English) AND $\mathrm{SO}=$ (Academy of Management Journal OR Administrative Science Quarterly OR Asia Pacific Journal of Management OR British Journal of Management OR Business History OR Canadian Journal of Administrative Sciences Revue Canadienne Des Sciences De L Administration OR European Management Journal OR Global Strategy Journal OR Journal of Business Ethics OR Journal of Business Research OR Journal of Management OR Journal of Management Inquiry OR Journal of Management Studies OR Management And Organization Review OR Management Decision OR Management Science OR Organization OR Organization Science OR Organization Studies OR Research In The Sociology of Organizations OR Research Policy OR Scandinavian Journal of Management OR Strategic Management Journal OR Strategic Organization)

Uzyskujemy 554 rezultaty. Jest to liczba publikacji stosunkowo łatwa do przeanalizowania w następnych etapach procedury SPL, musimy jednak pamiętać, że szanse publikacyjne rezultatów takiego przeglądu będą w decydującym stopniu zależeć od naszego wyczucia przekonań panujących w środowisku naukowym. Zwróćmy też uwagę, że bardzo daleko odeszliśmy od wstępnych założeń metodyki SPL, która nakazuje analizę wszystkich publikacji empirycznych na dany temat. Pamiętajmy również, że systematyczne przeglądy literatury są chętnie publikowane, ponieważ autor/rzy przeglądu wykonują mrówczą pracę na rzecz innych naukowców. Im mniejsza liczba badań, które przeanalizujemy, tym mniejsza korzyść dla przyszłych czytelników SPL, a więc i niższa skłonność recenzentów i redaktorów do przyjęcia SPL do druku.

\subsection{Przykład 3. Temat SPL: cyberloafing}

Nasze wstępne poszukiwania publikacji na temat cyberloafingu wykazały, że jest ich stosunkowo niewiele. Rozpoczynamy od ciągu wyszukiwawczego, który na dwa sposoby różni się od użytych w innych przykładach: zawiera wiele synonimów poszukiwanego pojęcia i nie zawiera ograniczenia do periodyków przypisanych do dyscypliny nauki o zarządzaniu. Nie zdecydowaliśmy się na to drugie ograniczenie, ponieważ temat SPL nie może być łatwo przypisany do żadnej konkretnej dyscypliny naukowej. 
$\mathrm{TS}=$ (cyberloafing OR cyberslacking OR cyberdeviance OR "cyber deviance" OR "non-work-related computing" OR "workplace Internet leisure browsing" OR "Internet abuse" OR "workplace internet deviance" OR "personal use of the Internet")

Uzyskujemy 252 rezultaty. Wyłączamy publikacje, które nie zawierają wyników empirycznych:

$\mathrm{TS}=$ (cyberloafing OR cyberslacking OR cyberdeviance OR "cyber deviance" OR "non-work-related computing" OR "workplace Internet leisure browsing" OR "Internet abuse" OR "workplace internet deviance" OR "personal use of the Internet") NOT DT $=($ Book Review OR Editorial Material OR Discussion OR Letter OR Meeting Abstract OR Meeting Summary OR Review) NOT IS=(0363-7425 OR 1930-3807)

Otrzymaliśmy 236 rezultatów. Na tym kończymy dodawanie kryteriów do zapytania. Postępujemy tak z dwóch powodów. Po pierwsze, dalsze ograniczenie wymagałoby zawężenia wyszukiwania tylko do artykułów opublikowanych w pismach naukowych. O ile w naukach o zarządzaniu jest to praktyka powszechna, o tyle w przypadku badań nad cyberloafingiem zastosowanie takiego ograniczenia byłoby poważnym błędem, ponieważ temat naszego SPL zahacza o informatykę. W tej nauce bardzo ważną rolę odgrywa rozpowszechnianie wyników badań w prezentacjach konferencyjnych - świat technologii informatycznych zmienia się zbyt szybko by czekać dwa-trzy lata aż artykuł zostanie opublikowany w piśmie naukowym. Dlatego wyeliminowanie z ciągu wyszukiwania materiałów konferencyjnych, mogłoby doprowadzić do niekompletnego rozpoznania badanego tematu. Po drugie, liczba uzyskanych rezultatów jest na tyle niewielka, że obawiamy się raczej tego, iż będziemy mieli zbyt mało źródeł do sporządzenia SPL niż zbyt dużo.

\subsection{Przykład 4. Temat SPL: wpływ outsourcingu na wyniki przedsiębiorstw}

Jeśli chcielibyśmy przenalizować zależność między wprowadzaniem outsourcingu a wydajnością, to początkowe wyszukiwanie będzie stosunkowo mało złożone. Można przyjąć, że wszystkie publikacje traktujące o outsourcingu używają tego pojęcia. Jednocześnie, trudno wyobrazić sobie publikację dotyczącą wpływu na wyniki przedsiębiorstw, która nie używałaby słowa „performance”. Zarazem wiemy, że publikacje dotyczące outsourcingu mogą ukazywać się pismach ekonomicznych (teoria kosztów transakcyjnych), informatycznych 
(outsourcing usług IT), służby zdrowia, administracji publicznej (Nowe Zarządzanie Publiczne) i innych. Dlatego nie możemy ograniczyć przeszukiwania do dyscypliny „management”. Rozpoczynamy zatem przygotowanie zapytania od następującego ciągu wyszukiwawczego:

$$
\mathrm{TS}=(\text { outsourcing AND performance) }
$$

Uzyskaliśmy 3766 rezultatów. Wykluczamy publikacje niezawierające wyników badań empirycznych:

$\mathrm{TS}=($ outsourcing AND performance $)$ NOT DT $=($ Book Review OR Editorial Material OR Discussion OR Letter OR Meeting Abstract OR Meeting Summary OR Review) NOT IS=(0363-7425 OR 1930-3807)

Otrzymujemy 3668 rezultatów. Ograniczamy do publikacji w języku angielskim:

$\mathrm{TS}=$ (outsourcing AND performance) $\mathrm{NOT} \mathrm{DT}=($ Book Review OR Editorial Material OR Discussion OR Letter OR Meeting Abstract OR Meeting Summary OR Review) NOT IS $=(0363-7425$ OR 1930-3807) AND LA $=($ English)

Wyszukiwanie odnajduje 3619 publikacji. Jeśli chcemy postępować zgodnie z praktyką często stosowaną w naukach o zarządzaniu polegającą na ograniczeniu SPL do artykułów naukowych, poszerzamy zakres wykluczonych typów publikacji:

$\mathrm{TS}=($ outsourcing AND performance $)$ AND DT $=($ Article OR Early Access

OR Correction OR Retracted Publication) NOT IS $=(0363-7425$ OR 1930-3807) AND LA=(English)

Uzyskujemy 2543 wyników. Z poszukiwania wcześniejszych SPL i metaanaliz przeprowadzonego w pierwszym etapie procedury (sekcja 1.3) wiemy, że istnieje wiele wcześniejszych tego typu publikacji. Przyjmijmy, że ostatni poprawnie zrealizowany systematyczny przegląd literatury ukazał się w roku 2014 i obejmuje literaturę opublikowaną do roku 2012. Możemy do naszego zapytania wprowadzić ograniczenie, które pozwoli zawęzić rezultaty do publikacji wydanych po 2012 roku: 
$\mathrm{TS}=$ (outsourcing AND performance $)$ AND DT $=($ Article OR Early Access

OR Correction OR Retracted Publication) NOT IS $=(0363-7425$ OR 1930-3807) AND LA=(English) AND PY=(2013-2021)

UWAGA: Podając koniec przedziału czasowego (PY), warto dodać 1 do bieżącego roku. Pisma naukowe stosunkowo często publikują teksty awansem, tj. tekst ukazuje się w roku 2020, ale jest umieszczony w numerze pisma datowanym na rok 2021. Takie poszerzenie zakresu wyszukiwania ma szczególne znaczenie, jeśli pracę nad SPL prowadzimy w drugiej połowie roku.

Uzyskujemy 1677 wyników, które powinny stać się podstawą SPL. Jeśli jednak chcielibyśmy dalej zawęzić zakres wyszukiwania, możemy zwrócić uwagę, że interesuje nas wpływ outsourcingu na wyniki przedsiębiorstw, a więc możemy wyłączyć publikacje, które dotyczą wyników w sektorze publicznym i administracji publicznej. Nie jest to wcale zadanie łatwe. Możemy próbować ograniczyć wyszukiwanie, posługując się kategoriami WoS i dodając do zapytania polecenie NOT $\mathrm{WC}=$ (public administration). $\mathrm{W}$ ten sposób zmniejszymy jednak liczbę rezultatów zaledwie o 26 artykułów, jednocześnie narażając się na zarzut ze strony recenzentów (badania prowadzone w sektorze publicznym i administracji publicznej mogą przecież dostarczać wiedzy o outsourcingu istotnej z punktu widzenia przedsiębiorstw komercyjnych). Dlatego takie ograniczenie wydaje się generować więcej kosztów niż korzyści.

\subsection{Wyszukiwanie w drugiej bazie}

Po zakończeniu tworzenia ciągów wyszukiwawczych w pierwszej z baz wybranych jako podstawa SPL (w przykładach powyżej było to Web of Science) tworzymy zapytanie do drugiej z baz (na przykład Scopus). Musimy pamiętać, że zapytanie do drugiej z baz nie może zawierać żadnych dodatkowych kryteriów i musi zawierać wszystkie kryteria wykorzystane w pierwszej bazie.

Przykładowo, zapytanie do Web of Science dotyczące cyberloafingu:

TS $=$ (cyberloafing OR cyberslacking OR cyberdeviance OR "cyber deviance" OR "non-work-related computing" OR "workplace Internet leisure browsing" OR "Internet abuse" OR "workplace internet deviance" OR "personal use of the Internet") NOT DT=(Book Review OR Editorial Material OR Discussion OR Letter OR Meeting Abstract OR Meeting Summary OR Review) NOT IS $=(0363-7425$ OR 1930-3807) 
przetłumaczone na język Scopus przyjmie następującą postać:

TITLE-ABS-KEY(cyberloafing OR cyberslacking OR cyberdeviance OR "cyber deviance" OR "non-work-related computing" OR "workplace Internet leisure browsing" OR "Internet abuse" OR "workplace internet deviance" OR "personal use of the Internet") AND NOT DOCTYPE(bz OR ed OR le OR no OR pr OR re) AND NOT ISSN(0363-7425 OR 1930-3807)

i pozwoli odnaleźć 323 dokumenty.

\subsection{Pobranie rezultatów wyszukiwania i usuwanie duplikatów}

Po przeprowadzeniu wyszukiwania w każdej z baz pobieramy ich rezultaty do menedżera literatury (sposób pobierania wyników do Mendeley zostały przedstawiony w rozdziale 7). Pamiętamy by zanotować liczbę odnalezionych rezultatów dla każdej z baz. Będą one potrzebne na etapie tworzenia raportu z SPL.

W kolejnym kroku usuniemy duplikaty, to jest publikacje, które znaleźliśmy dwa razy, ponieważ występowały w obu przeszukiwanych bazach. Jednak najpierw sprawdzamy czy w rezultatach pobranych z każdej z baz nie występują duplikaty. Teoretycznie nie powinno się to zdarzyć, ale bazy danych i opisy bibliograficzne są tworzone przez ludzi, dlatego tego typu błędy są nieuchronne. W celu odnalezienia duplikatów wchodzimy w menu „Tools”, klikamy „Check for Duplicates". Pojawią się wyniki sprawdzenia (rysunek 2). Sprawdzamy czy rzeczywiście dwa odnalezione wpisy w bazie danych są identyczne (z prawej strony ekranu Mendeley wyświetla wyniki porównania dokumentów: pola, w których występują różnice nie mają znaczka w kwadracie). Następnie klikamy „Confirm Merge”. Pamiętamy o tym, by w naszych notatkach zaktualizować liczbę odnalezionych źródeł. 


\section{Rysunek 2. Usuwanie duplikatów z wyników wyszukiwania}

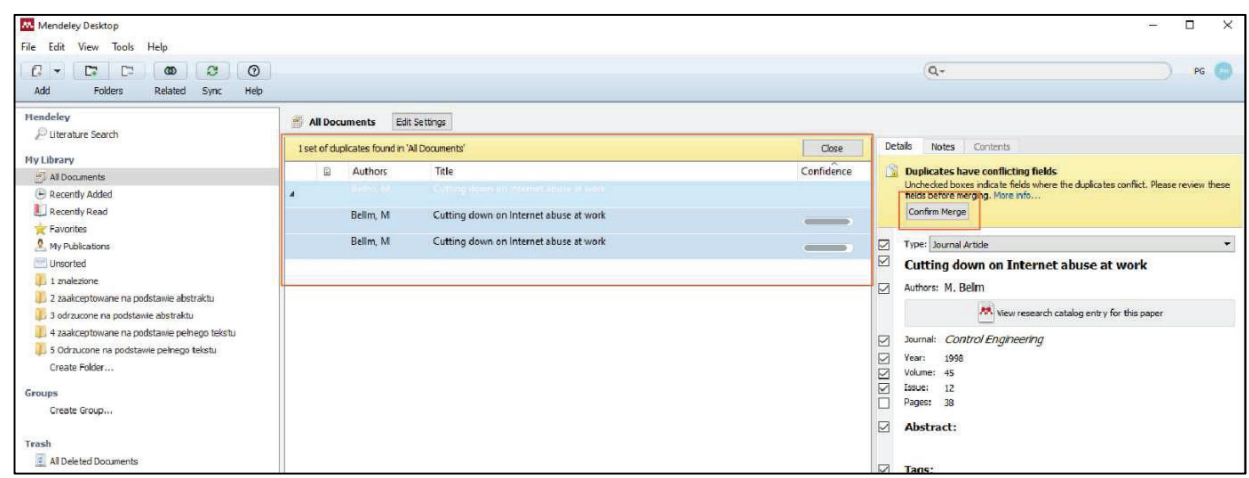

Po usunięciu duplikatów z rezultatów każdego z wyszukiwań łączymy rezultaty z obu baz i ponownie szukamy duplikatów, zgodnie ze schematem przedstawionym powyżej. Uwaga, jeśli zaimportujemy wyniki jednego wyszukiwania do drugiego, to Mendeley sam usunie duplikaty, nie pytając nas czy tego chcemy.

Przykład. Temat SPL: Cyberloafing. Wyszukiwanie publikacji dotyczących cyberloafingu pozwoliło odnaleźć 236 rezultaty w Web of Science i 323 rezultaty w Scopus, czyli w sumie mamy 559 źródeł. Poszukiwanie duplikatów w rezultatach każdej z baz pozwoliło wyeliminować dwa powtarzające się teksty (po jednym w WoS i Scopus). Automatyczna eliminacja publikacji powtarzających się w obu bazach pozwoliła stwierdzić, że odnaleźliśmy 357 unikatowych źródeł.

W kolejnym kroku przeglądamy listę, poszukując duplikatów, które nie zostały wykryte przez Mendeley. W tym celu dobrze jest posortować listę rezultatów po tytule i przeglądać czy następujące po sobie pozycje nie są identyczne. Jest to rozwiązanie lepsze niż sortowanie po nazwisku autora, ponieważ w bazach bibliograficznych stosunkowo często imię jest błędnie wpisane do pola nazwisko i odwrotnie, co spowoduje, że sortowanie po nazwisku utrudni odnalezienie duplikatów. Również w pisowni nazwisk zdarzają się błędy, szczególnie jeśli nazwiska wykorzystują znaki diakrytyczne niewystępujące w języku angielskim. Uznajemy, że mamy do czynienia z duplikatem, jeśli publikacja ma ten sam tytuł, autorów i miejsce publikacji (periodyk) co inna publikacja na naszej liście.

Poszukiwanie duplikatów pozwoliło zmniejszyć liczbę źródeł do 346.

Wyniki tego etapu notujemy w tabeli, która będzie przydatna przy sporządzaniu raportu z systematycznego przeglądu literatury (tabela 2). Nie wszystkie informacje $\mathrm{z}$ tej tabeli będziemy podawać $\mathrm{w}$ ostatecznym raporcie z SPL, ale warto je zanotować na wypadek gdybyśmy musieli sporządzić aktualizację SPL (na przykład ze względu na długotrwały cykl wydawniczy). 
Tabela 2. Rezultaty wyszukiwania i eliminacji duplikatów

\begin{tabular}{|r|l|r|r|r|}
\hline \multicolumn{2}{|l}{ Web of Science } & Scopus & Suma \\
\hline 1 & Znalezione & 236 & 323 & 559 \\
\hline 2 & Duplikaty & 1 & 1 & 2 \\
\hline 3 & Po usunięciu duplikatów & 235 & 322 & 557 \\
\hline 4 & po połączeniu & & \\
\hline 5 & $\begin{array}{l}\text { Liczba duplikatów znalezionych } \\
\text { automatycznie }\end{array}$ & 200 & \\
\hline 6 & Liczba duplikatów znalezionych ręcznie & & 11 & \\
\hline 7 & $\begin{array}{l}\text { Liczba źródeł po usunięciu duplikatów } \\
(=3-5-6)(\text { rezultat etapu 3) }\end{array}$ & 346 & \\
\hline
\end{tabular}




\section{Rozdział 4 \\ Kwalifikacja na podstawie tytułów i abstraktów}

Na poprzednich etapach procedury sporządzania SPL posługiwaliśmy się jedynie automatycznymi metodami kwalifikacji tekstu: sprawdzaliśmy czy opis bibliograficzny zawiera słowa kluczowe i czy spełnia warunki, takie jak miejsce i data publikacji. W kolejnym etapie procedury analizujemy odnalezione publikacje na podstawie tytułu i abstraktu, by sprawdzić czy teksty, które znaleźliśmy rzeczywiście odpowiadają kryteriom wyszukiwania.

Jeśli lektura tytułu i abstraktu nie pozwala jednoznacznie stwierdzić, czy publikacja spełnia nasze kryteria, to powinniśmy ją zakwalifikować do kolejnego etapu analizy, w którym będziemy czytać pełen tekst publikacji.

$\mathrm{Z}$ naszej listy będziemy odrzucać teksty, które a) są niezgodne z tematem SPL i/lub b) nie są zgodne $z$ formalnymi kryteriami wyszukiwania.

\subsection{Niezgodność z tematem SPL}

Jednym z powodów eliminacji tekstu z dalszej analizy jest niezgodność tematyczna $\mathrm{z}$ tematem sporządzanego przeglądu literatury. Należy pamiętać o tym, by podczas przeglądania kolejnych pozycji na liście wyników zawsze stosować się do tych samych kryteriów włączania/wyłączania publikacji z listy. Na tym etapie jest zbyt późno na zmianę tematu badania. Jeśli chcielibyśmy jej dokonać, to będziemy musieli wrócić do etapu 1 i na nowo sformułować pytanie badawcze.

Przykład 1: W streszczeniu publikacji Abd Rahman, N., Razali, N.S., Ali, S.A.M. et al. (2014). Digital Etiquette: Educating Primary School Children via Mobile Game Application. Sintok: Univ Utari Malaysia-Uum, czytamy:

"The purpose of this paper is to build awareness on digital etiquette among primary school children. An online survey was conducted to assess the children's understanding and awareness about digital etiquette. The online survey was 
distributed via social network sites (such as Facebook, Twitter and Google+) to parents or guardians with children aged between 7 to 12 years old".

Zarówno tytuł, jak i abstrakt jednoznacznie wskazują, że badanymi byli rodzice, a celem badania było określenie świadomości dzieci co do etykiety obowiązującej w Internecie. Nasze pytanie badawcze dotyczy cyberloafingu, czyli korzystania z Internetu w celach prywatnych w miejscu pracy, zatem tekst nie spełnia kryteriów merytorycznych i zostaje wykluczony z dalszej analizy.

\subsection{Niezgodność z kryteriami formalnymi}

Publikacja zostanie również wykluczona $\mathrm{z}$ dalszej analizy, jeśli nie spełnia któregoś z kryteriów formalnych określonych w etapie 2. Przykładowo, jeśli celem SPL jest agregacja wyników empirycznych, to z listy publikacji wyłączymy teksty teoretyczne.

\section{Typ publikacji niezgodny z kryteriami zapytania}

Przykład 2: Wśród źródeł dotyczących cyberloafingu znajduje się publikacja:

15 th Americas Conference on Information Systems, AMCIS 2009, Volume 3. (2009). 15th Americas Conference on Information Systems 2009, AMCIS 2009.

W pierwszych zdaniach abstraktu czytamy:

„The proceedings contain 78 papers. The special focus in this conference is on information systems, technologies, the developments of technologies and engineering in America".

Tekst stanowi podsumowanie rezultatów konferencji w związku z tym nie powinien znaleźć się w wynikach wyszukiwania, ponieważ w zapytaniu stwierdziliśmy, że wykluczamy kategorię dokumentów oznaczonych „meeting abstract”. Interesują nas pojedyncze referaty wygłoszone podczas konferencji, ale nie interesuje na zbiorcze omówienie tych referatów. Dlatego tekst odrzucamy.

Przykład 3: W rezultatach znajduje się publikacja:

Askew, K., Buckner, J.E., Taing, M.U., et al. (2019). Erratum to "Explaining Cyberloafing: The Role of the Theory of Planned Behavior" [Computers in Human Behavior 36C 510-519]. Computers in Human Behavior, 90, 284-284. 
Tytuł i abstrakt wskazują, że jest to errata do wcześniej opublikowanego tekstu, prostująca błędnie podaną afiliację jednego z autorów. Tekst odrzucamy. Pamiętajmy o tym, że w zapytaniu do baz nie wyeliminowaliśmy publikacji oznaczonych jako „Correction” ponieważ takie publikacje mogą informować o błędach poważniejszych niż źle podana afiliacja autora.

\section{Tekst zawiera przegląd literatury, metaanalizę lub jest pracą teoretyczną}

Jeśli celem SPL jest odnalezienie wyników badań empirycznych, musimy z naszej bazy usunąć przeglądy literatury, metaanalizy i prace teoretyczne.

Stosunkowo łatwo odnaleźć przeglądy literatury i metaanalizy. Jeśli w abstrakcie znajdziemy słowa „systematic review”, „review of literature”, „meta-analysis", to w większości przypadków będą to wystarczające przesłanki do odrzucenia tekstu.

Trudniejsze jest odnalezienie tekstów teoretycznych. Odnajdywanie tekstów teoretycznych możemy przeprowadzić sprawniej, zwracając szczególną uwagę na pewne słowa kluczowe. Jeśli w abstrakcie znajdziemy jakiekolwiek liczby, odniesienia do lokalizacji geograficznych (Poland, New York) lub słowa takie jak: „evidence”, „hypothesis”, „sample”, „results”, „study 1”, „study 2”, „test” to prawdopodobnie nie mamy do czynienia $\mathrm{z}$ tekstem teoretycznym.

Przykład 4: Jak już wiemy ze wstępnej analizy przeprowadzonej w rozdziale 1, wśród odnalezionych publikacji znajduje się pozycja: Mercado, B.K., Giordano, C., \& Dilchert, S. (2017). A meta-analytic investigation of cyberloafing. Career Development International, 22(5), 546.

W abstrakcie czytamy:

„After a systematic literature search, the authors conducted psychometric meta-analyses to estimate the relationships of 39 different correlates with cyberloafing. The meta-analytic database was comprised of 54 independent samples contributing 609 effect sizes".

Zarówno tytuł, jak i abstrakt wskazują, że mamy do czynienia z metaanalizą, odrzucamy zatem tę publikację z naszej bazy (pomijam w tym momencie, że moglibyśmy ograniczyć nasze wyszukiwanie do publikacji, które ukazały się po sporządzeniu tej metaanalizy).

Przykład 5: W rezultatach odnajdujemy publikację: Burleson, J., \& Greenbaum, B.E. (2019). When Spheres Collide: A Refocused Research Framework for Personal Use of Technology at Work. Communications of the Association for Information Systems, 45, 411-432. 
W abstrakcie czytamy:

"In this paper, we offer an updated definition and refocused research framework that uses novel insights drawn from the multitasking literature to guide researchers in addressing a central question: how can employees most effectively manage their personal use of technology at work?".

Zatem mamy do czynienia z tekstem teoretycznym/definicyjnym, w którym nie raportuje się wyników badań empirycznych. Tekst odrzucamy, ponieważ celem naszego SPL jest analiza wyników empirycznych.

W rezultacie etapu 4 otrzymujemy listę publikacji, które zostały zakwalifikowane do kolejnego etapu analizy. Dodajemy kolejne wiersze do tabeli sporządzonej na etapie 3, zapisując, ile tekstów zostało odrzuconych i z jakiego powodu (tabela 1).

Tabela 1. Rezultaty eliminacji źródeł na podstawie analizy tytułu i abstraktu (kontynuacja tabeli 2 z sekcji 3.6)

\begin{tabular}{|c|c|c|c|c|}
\hline & & Web of Science & Scopus & Suma \\
\hline 1 & Znalezione & 236 & 323 & 559 \\
\hline 2 & Duplikaty & 1 & 1 & 2 \\
\hline 3 & Po usunięciu duplikatów & 235 & 322 & 557 \\
\hline 4 & & po połączeniu & & \\
\hline 5 & $\begin{array}{l}\text { Liczba duplikatów znalezionych } \\
\text { automatycznie }\end{array}$ & & 200 & \\
\hline 6 & Liczba duplikatów znalezionych ręcznie & & 11 & \\
\hline 7 & $\begin{array}{l}\text { Liczba źródeł po usunięciu duplikatów } \\
(=3-5-6) \text { (rezultat etapu 3) }\end{array}$ & & 346 & \\
\hline 8 & Liczba źródeł niezgodnych z tematem SPL & & 82 & \\
\hline 9 & $\begin{array}{l}\text { Liczba źródeł niespełniających kryteriów } \\
\text { formalnych }\end{array}$ & & 81 & \\
\hline 10 & $\begin{array}{l}\text { Liczba źródeł zakwalifikowanych do } \\
\text { analizy na podstawie pełnego tekstu } \\
(=7-8-9) \text { (rezultat etapu } 4)\end{array}$ & & 183 & \\
\hline
\end{tabular}




\section{Rozdział 5}

\section{Analiza pełnego tekstu}

W piątym etapie przechodzimy do najważniejszego elementu procedury, czyli określenia stanu wiedzy na interesujący nas temat na podstawie lektury pełnych tekstów publikacji. Etap 5 składa się z czterech faz. W pierwszej pobieramy pliki PDF dla wszystkich badań, które w etapie 4 uznaliśmy za spełniające kryteria wyszukiwania. Pliki PDF pobieramy dopiero na tym etapie, aby uniknąć poszukiwania plików, które nie będą nam potrzebne, ponieważ zrezygnowaliśmy $\mathrm{z}$ analizy danego tekstu na podstawie lektury tytułu i abstraktu. W drugiej fazie prowadzimy dalsze poszukiwanie duplikatów i opracowań niezgodnych z tematem SPL, których nie udało się wyeliminować na etapach 3 i 4 . W trzeciej fazie czytamy pełen tekst by zidentyfikować wyniki uzyskane przez autorów. W czwartej — określamy trafność badania.

\subsection{Pobieranie plików PDF}

Dzięki usunięciu duplikatów i ewentualnych błędów w rezultatach uzyskaliśmy 346 publikacji, które zostały przenalizowane w etapie 4 . W wyniku tej analizy ograniczyliśmy liczbę publikacji do 183 . Zostaną one przeanalizowane na niniejszym etapie procedury. Jednak, aby było to możliwe musimy pobrać pliki PDF dla 183 źródeł, które znajdują się w naszej bazie.

Jest to niezwykle czaso- i pracochłonny etap procedury. Dla źródeł, które odnaleźliśmy w bazie Scopus możemy ułatwić sobie poszukiwanie plików, klikając w Mendeley w „View research catalog entry for this paper” (rysunek 1, ramka). Zostaniemy przekierowani na stronę Mendeley z danymi tekstu. Klikamy w „Get full text” (rysunek 2, ramka) i zostajemy przeniesieni do bazy bibliograficznej, gdzie prawdopodobnie (choć nie zawsze) znajduje się plik PDF. Jeśli znajdujemy się w sieci uniwersyteckiej, to plik będzie można od razu pobrać (zakładając, że uniwersytet ma wykupiony abonament w danej bazie). Jeśli pracujemy z innej lokalizacji, to będziemy musieli zalogować się do bazy. Pobrany plik podłączamy do danych bibliograficznych w sposób opisany w rozdziale 7.3.3. 
Rysunek 1. Szukanie plików PDF dla rezultatów ze Scopus

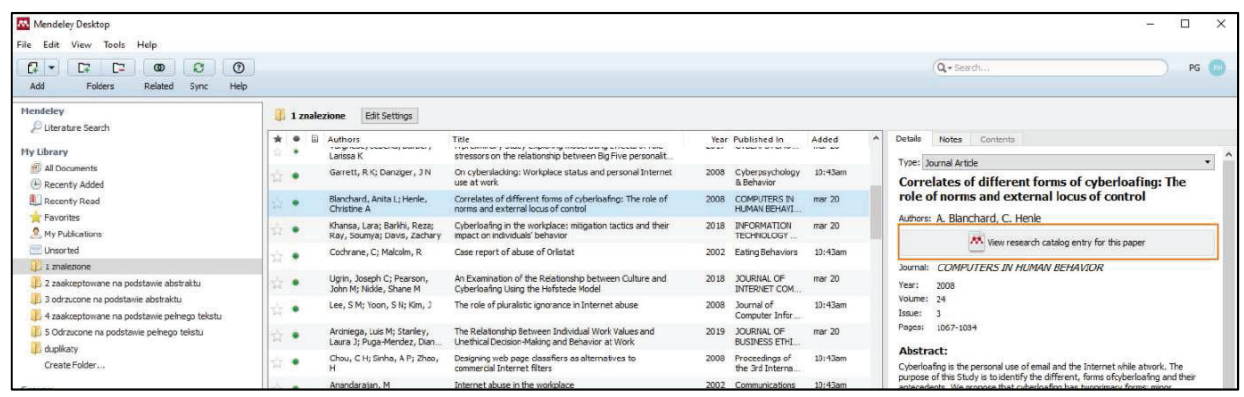

Rysunek 2. Pobieranie plików PDF dla rezultatów ze Scopus (cd.)

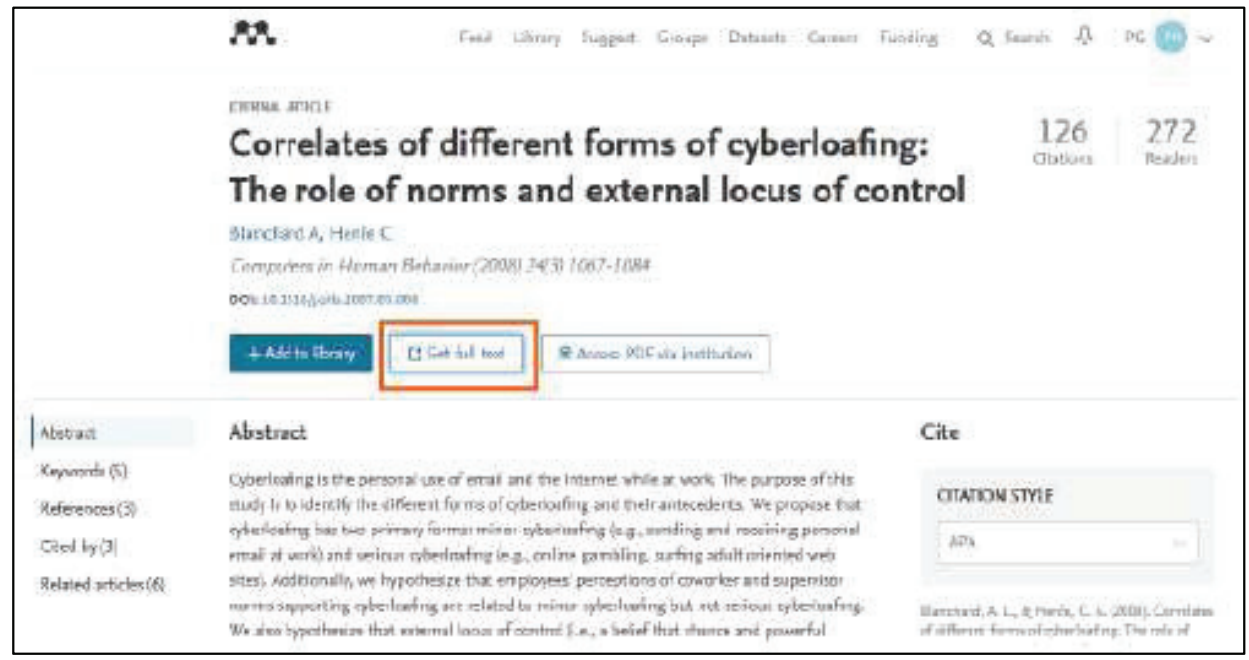

Osoby posługujące się aplikacją EndNote mogą zaoszczędzić sporo czasu, korzystając $z$ automatycznego pobierania plików PDF. W tym celu zaznaczamy rekordy, dla których chcemy pobrać pliki, wybieramy menu „References” na górnej belce aplikacji, następnie wybieramy „Find Full Text” i ponownie „Find Full Text...”. Jeśli jesteśmy podłączeni do sieci uniwersyteckiej od razu rozpocznie się szukanie i pobieranie plików (rysunek 3).

Jeśli pracujemy z innej lokalizacji musimy w preferencjach programu podać link do bazy danych, z której chcemy pobierać pliki (np. EBSCO). Dokonujemy tego, wybierając: „Edit” -> „Preferences”, a następnie w okienku, które się pokazało wybieramy kategorię „Find Full Text” i w polu „URL” wpisujemy link do bazy danych. Zatwierdzamy zmiany, wciskając OK, i rozpoczynamy poszukiwanie pełnych tekstów zgodnie z procedurą opisaną powyżej. W okienku, które się pojawi wpisujemy dane logowania do biblioteki. Aplikacja EndNote zacznie 
szukać i pobierać pliki. W zależności od źródeł, które chcemy pobrać w ten sposób udaje się znaleźć od 10 do $60 \%$ plików PDF. Uwaga: pomimo możliwości zalogowania się do systemu bibliotecznego spoza sieci uniwersytetu pobieranie plików działa lepiej (daje więcej pobranych plików), jeśli tę operację przeprowadzamy z komputera podłączonego do sieci uniwersyteckiej.

Wykorzystanie tej opcji programu EndNote pozwala zaoszczędzić dużo czasu, nie tylko dlatego, że pliki PDF są wyszukiwane i pobierane automatycznie, lecz także dlatego, że są automatycznie podłączane do odpowiednich rekordów w bazie danych.

\section{Rysunek 3. Pobieranie plików PDF w aplikacji EndNote}

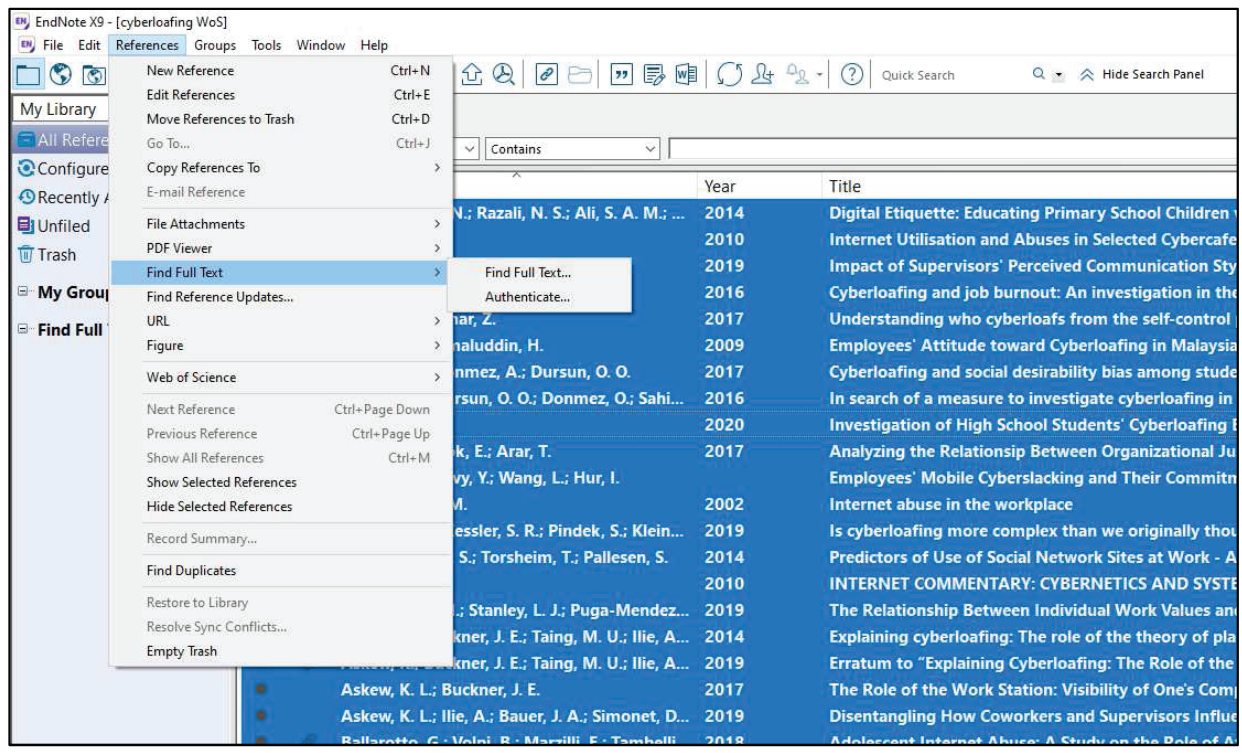

Jednak dla większości pozycji literaturowych nie uda nam się automatycznie znaleźć i pobrać plików PDF. W tej sytuacji trzeba ich szukać ręcznie w bazach bibliograficznych. Wybór tych baz zależy przede wszystkim od zakresu subskrypcji baz dla danej uczelni. W przypadku Uniwersytetu Warszawskiego najlepiej posługiwać się Multiwyszukiwarką naukową EDS, do której wejdziemy przez bazę Business Source Ultimate (EBSCO). Jednak nie do wszystkich plików PDF uda nam się dotrzeć bezpośrednio z tego źródła.

W takiej sytuacji musimy sprawdzić czy biblioteka ma wykupiony dostęp do bazy, w której znajduje się interesujący nas tekst. W tym celu sprawdzamy w jakim piśmie opublikowano artykuł, którego poszukujemy. Następnie wchodzimy na stronę zawierającą spis baz www.buw.uw.edu.pl/zasoby-online/bazyonline/. Wybieramy zakładkę „E-czasopisma” i klikamy w „Alfabetyczna lista 
e-czasopism" (rysunek 4). Na następnej stronie wpisujemy tytuł pisma, w którym ukazał się artykuł, dla którego chcemy pobrać plik PDF. Po kliknięciu w „Szukaj" otrzymamy listę baz, w których znajdziemy pliki dla tego pisma (rysunek 5). Należy zwrócić uwagę, że nie we wszystkich bazach znajdują się wszystkie roczniki danego pisma oraz że w niektórych bazach pliki są umieszczane dopiero po upływie okresu karencji, który może trwać nawet 6 lat. Na ogół, najszerszy dostęp do plików PDF znajdziemy w bazie wydawcy pisma (w przypadku Strategic Management Journal pokazanym na rysunku 5 jest to Wiley Online Library Full Collection).

\section{Rysunek 4. Poszukiwanie subskrypcji w Bibliotece Uniwersytetu Warszawskiego}

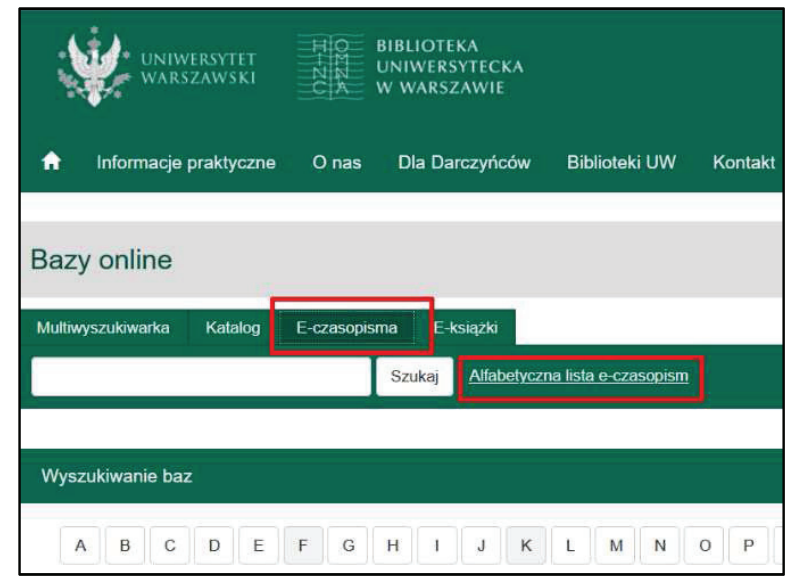

Rysunek 5. Poszukiwanie subskrypcji w Bibliotece Uniwersytetu Warszawskiego - c.d.

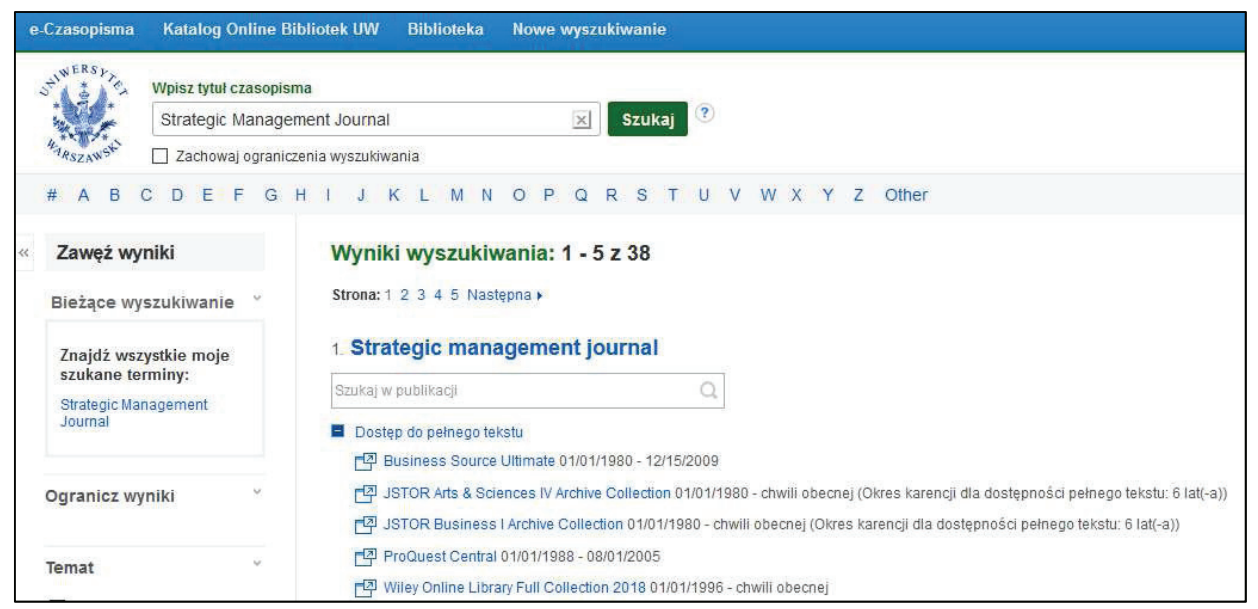


Jeśli nie uda nam się odnaleźć plików PDF w bazach dostępnych przez bibliotekę Uniwersytetu Warszawskiego, powinniśmy szukać w innych źródłach:

- Google Scholar. Przeszukiwania w Google Scholar najłatwiej przeprowadzić, posługując się Google Scholar Search Button (opisany w rozdziale 7).

- ResearchGate.net i academia.edu - platformy, na których naukowcy umieszczają swoje publikacje. Często znajdziemy tam jedynie maszynopisy zaakceptowane do druku zamiast ostatecznych wersji tekstu.

Jeśli wszystkie sposoby zawiodą a tekst, którego szukamy wydaje się ważny dla naszego SPL, można spróbować skorzystać z serwisu Subito oferowanego, między innymi, przez bibliotekę Uniwersytetu Warszawskiego. Usługa polega na przeskanowaniu materiałów znajdujących się w zasobach bibliotek uniwersytetów austriackich, niemieckich i szwajcarskich. Niestety jest to usługa płatna. Więcej informacji można znaleźć pod adresem www.buw.uw.edu.pl/informacjepraktyczne/jak-korzystac/

\subsection{Usuwanie duplikatów i źródeł niezgodnych z tematem przeglądu}

Na wcześniejszych etapach procedury wyeliminowaliśmy duplikaty, jednak uczyniliśmy to na podstawie zbieżności tytułów i miejsca publikacji. Dokładna inspekcja rezultatów wyszukiwania ujawnia, że w dalszym ciągu znajdują się wśród nich duplikaty, ale innego rodzaju. Nim tekst naukowy zostanie opublikowany w periodyku jest na ogół prezentowany podczas konferencji. W SPL na temat cyberloafingu uwzględniliśmy publikacje pokonferencyjne, ponieważ tematyka SPL obejmuje badania prowadzone w dziedzinie informatyki, to jest dyscypliny, w której upowszechnianie wyników w publikacjach pokonferencyjnych odgrywa ważną rolę. Lektura tytułów i abstraktów ujawnia, że wśród wyników wyszukiwania znajdują się następujące pozycje:

Li, H., Zhang, J., \& Sarathy, R. (2009). Understanding the compliance with the internet use policy from a criminology perspective. In $15^{\text {th }}$ Americas Conference on Information Systems 2009, AMCIS 2009 (Vol. 5, pp. 3278-3285).

Li, H., Sarathy, R., \& Zhang, J. (2010). Understanding compliance with internet use policy: An integrative model based on command-and- control and self-regulatory approaches. In ICIS 2010 Proceedings - Thirty First International Conference on Information Systems.

Li, H., Zhang, J., \& Sarathy, R. (2010). Understanding compliance with internet use policy from the perspective of rational choice theory. Decision Support Systems, 48(4), 635-645. 
Wszystkie trzy publikacje zostały przygotowane przez ten sam zespół autorów (choć w ostatniej zmieniła się ich kolejność) i noszą bardzo podobne tytuły. Analiza pełnego tekstu wskazuje, że są to trzy wersje tekstu referującego rezultaty tego samego badania - dwie prezentacje konferencyjne i finalna publikacja w piśmie Decision Support Systems. W związku z tym z naszej listy eliminujemy publikacje pokonferencyjne i zachowujemy jedynie publikację $\mathrm{w}$ periodyku naukowym. Jednocześnie pamiętajmy, że tego rodzaju duplikaty możemy eliminować tylko na podstawie lektury całego tekstu. Zdarza się, że pierwsze wersje tekstów (konferencyjne) zawierają więcej wyników (np. dodatkowe hipotezy), które znikają w ostatecznej publikacji w periodyku naukowym. Tego rodzaju zmiany szczególnie często zachodzą w przypadku hipotez, które nie uzyskały wsparcia w badaniu, ponieważ redakcje pism niechętnie publikują takie rezultaty (patrz sekcja 5.4.4). Z podobną sytuacją będziemy mieli do czynienia w przypadku artykułów naukowych opartych na badaniach przeprowadzonych do doktoratu. Przeważnie doktorat zawiera więcej wyników zerowych (brak wsparcia dla hipotezy) niż ostateczna publikacja. Zdarza się również, że wyniki, które w doktoracie nie osiągnęły istotności statystycznej, w ostatecznej publikacji w piśmie naukowym jednak istotność statystyczną zyskują (Mazzola \& Deuling, 2013; O’Boyle, Banks, \& Gonzalez-Mulé, 2017) (patrz sekcja 5.4.4).

$\mathrm{Na}$ tym etapie eliminujemy również teksty, które na podstawie analizy tytuły i abstraktu uznaliśmy za zgodne z tematem SPL, jednak po lekturze całego tekstu okazały się być z tym tematem niezgodne. Może się także zdarzyć, że znajdziemy publikacje niespełniające kryteriów formalnych (np. bardzo dobrze zakamuflowany tekst teoretyczny).

W wyniku tych inspekcji aktualizujemy tabelę, która rozpoczęliśmy sporządzać na etapie 3 i zaktualizowaliśmy na etapie 4 (tabela 1). 
Tabela 1. Rezultaty eliminacji źródeł na podstawie analizy pełnego tekstu (kontynuacja tabel 2 z sekcji 3.6 i 1 z sekcji 4)

\begin{tabular}{|c|c|c|c|c|}
\hline & & Web of Science & Scopus & Suma \\
\hline 1 & Znalezione & 236 & 323 & 559 \\
\hline 2 & Duplikaty & 1 & 1 & 2 \\
\hline 3 & Po usunięciu duplikatów & 235 & 322 & 557 \\
\hline 4 & & \multicolumn{3}{|l|}{ po połączeniu } \\
\hline 5 & Liczba duplikatów znalezionych automatycznie & \multicolumn{3}{|c|}{200} \\
\hline 6 & Liczba duplikatów znalezionych ręcznie & \multicolumn{3}{|c|}{11} \\
\hline 7 & $\begin{array}{l}\text { Liczba źródeł po usunięciu duplikatów } \\
(=3-5-6) \text { (rezultat etapu 3) }\end{array}$ & \multicolumn{3}{|c|}{346} \\
\hline 8 & Liczba źródeł niezgodnych z tematem SPL & \multicolumn{3}{|c|}{82} \\
\hline 9 & $\begin{array}{l}\text { Liczba źródeł niespełniających kryteriów } \\
\text { formalnych }\end{array}$ & \multicolumn{3}{|c|}{81} \\
\hline 10 & $\begin{array}{l}\text { Liczba źródeł zakwalifikowanych do analizy } \\
\text { na podstawie pełnego tekstu(=7-8-9) } \\
\text { (rezultat etapu 4) }\end{array}$ & \multicolumn{3}{|c|}{183} \\
\hline 11 & Liczba źródeł niezgodnych z tematem SPL & \multicolumn{3}{|c|}{51} \\
\hline 12 & $\begin{array}{l}\text { Liczba źródeł niespełniających kryteriów } \\
\text { formalnych }\end{array}$ & \multicolumn{3}{|c|}{6} \\
\hline 13 & $\begin{array}{l}\text { Liczba źródeł wykorzystanych jako podstawa } \\
\text { SPL (=10-11-12) (rezultat etapu 5) }\end{array}$ & \multicolumn{3}{|c|}{126} \\
\hline
\end{tabular}

\subsection{Analiza wyników}

Celem SPL jest podsumowanie tego, co dotychczas stwierdzono na interesujący nas temat. W tym celu musimy przeczytać wszystkie teksty, które zakwalifikowały się do tego etapu procedury.

Badania odnalezione w bazach bibliograficznych przeszły już pierwsze dwa sita selekcji: wyeliminowaliśmy duplikaty na etapie 3 , by potem odrzucić publikacje niespełniające naszych kryteriów na etapie 4. Odrzuciliśmy też część tekstów na obecnym etapie (sekcja 5.2). Dalsza analiza zależy od typu pytania badawczego, które sformułowaliśmy: agregacja empirii czy próba stworzenia konceptualnej mapy badań.

\section{Agregacja wyników empirycznych}

Teksty zgodne z określonymi przez nas kryteriami czytamy w całości, zwracając szczególną uwagę na dwie spośród typowych sekcji tekstu naukowego. Publi- 
kacje w naukach o zarządzaniu (podobnie jak większości innych nauk empirycznych) składają się przeważnie z sześciu elementów:

1. Wstęp (Introduction) - autorzy wstępnie pokazują lukę badawczą (czego nie wiadomo), sygnalizują pytanie/a badawcze, wykorzystaną metodę, a często również uzyskane wyniki. Wstęp można traktować jako poszerzoną wersję streszczenia (abstraktu). W tradycji anglosaskiej przywiązuje się ogromną wagę do treści wstępu, ponieważ większość czytelników czyta jedynie wstęp i wnioski (pomijamy tych, którzy czytają tylko abstrakt).

2. Teoria (Theory/Theoretical considerations/Research framework) - sekcja, w której autorzy omawiają dotychczasowe wyniki/teorie, by sformułować pytania badawcze i hipotezy. W polskiej tradycji często ta sekcja bywa nazywana przeglądem literatury, jednak nie chodzi tu po prostu o zreferowanie wcześniejszych publikacji, lecz o pokazanie jak hipotezy/pytania badawcze wynikają ze wcześniejszej literatury i dlaczego odpowiedź na nie przyczyni się do rozwoju teorii. W tej sekcji znajdziemy także sformułowanie hipotez.

3. Metody (Methods/Research Methods/Methodology) - sekcja, w której autorzy informują w jaki sposób przeprowadzili badanie: kto był badany, kiedy, jaka była wielkość próby, sposób doboru do próby, jakie narzędzia pomiaru i analizy zastosowano.

4. Wyniki (Results/Findings) - sekcja przedstawiająca wyniki badania. W artykułach opartych na metodach ilościowych jest przeważnie krótka (od jednej do kilku stron), podczas gdy w tekstach opartych na metodach jakościowych może zajmować nawet ponad 10 stron.

5. Dyskusja (Discussion) - sekcja, w której autorzy dyskutują wyniki, to znaczy pokazują w jaki sposób uzyskane rezultaty badań pozwalają rozwinąć teorię. Wiele pism naukowych zaleca również formułowanie implikacji dla praktyki zarządzania (Hensel, 2018a), jednak to zalecenie bywa często ignorowane przez autorów. Ważnym elementem tej części tekstu jest sekcja „Limitations/ boundary conditions and further research”, w której autorzy prezentują ograniczenia swojego badania.

6. Wnioski (Conclusions) - podsumowanie tekstu, na ogół jest skrótowym powtórzeniem wstępu i dyskusji.

Podczas lektury odnalezionych publikacji powinniśmy koncentrować naszą uwagę na sekcjach „Methods” oraz „Results”. Naszym celem jest agregacja wyników empirycznych, możemy zatem mniej koncentrować się na lekturze teorii, jak i dyskusji wyników. Nie interesuje nas, co autorzy sądzą na temat uzyskanych przez siebie rezultatów. Wiemy, że każdy autor (włączając w to niżej podpisanego) przecenia wartość swoich badań i ich znaczenie dla rozwoju teorii. Dlatego interesuje nas przede wszystkim empiria.

W przypadku tekstów ilościowych postępujemy w sposób następujący: W sekcji „Theory” odnajdujemy i wynotowujemy hipotezy, z sekcji „Methods” wyno- 
towujemy definicje konstruktów użytych w hipotezie oraz ich operacjonalizacje. Jest prawdopodobne, że różne badania odmiennie definiują i mierzą konstrukty, zatem w przypadku wystąpienia różnic między badaniami musimy sprawdzić czy posługiwano się w nich dokładnie tymi samymi konstruktami i operacjonalizacjami. Następnie w sekcji „Results” sprawdzamy czy hipoteza uzyskała wsparcie (tabela 2)1. Jednocześnie, dla całego badania wynotowujemy zastosowaną metodę i wielkość próby.

Tabela 2. Zbieranie wyników $\mathrm{z}$ analizowanych studiów

\begin{tabular}{|c|c|c|c|c|c|c|c|}
\hline Badanie & Metoda, próba & Hipoteza & $\begin{array}{c}\text { Zmienna } \\
\text { niezależna }\end{array}$ & $\begin{array}{c}\text { Definicja i } \\
\text { operacjonalizacja } \\
\text { zmiennej niezależnej }\end{array}$ & $\begin{array}{c}\text { Zmienna } \\
\text { zależna }\end{array}$ & $\begin{array}{c}\text { Definicja i } \\
\text { operacjonalizacja } \\
\text { zmiennej zależnej }\end{array}$ & $\begin{array}{l}\text { Uzyskała } \\
\text { wsparcie } \\
\text { (tak/nie) }\end{array}$ \\
\hline $\begin{array}{l}\text { Garrett } \\
\text { and } \\
\text { Danziger } \\
\text { (2008) }\end{array}$ & $\begin{array}{l}\text { ankieta telefoniczna, } \\
\text { USA, } 1024 \\
\text { respondentów } \\
\text { zatrudnionych } \\
\text { w przedsiębiorstwach }\end{array}$ & $\begin{array}{l}\text { H1: } \\
\text { Increasing job } \\
\text { dissatisfaction is } \\
\text { associated with } \\
\text { higher levels } \\
\text { of personal } \\
\text { Internet use } \\
\text { during work. }\end{array}$ & $\begin{array}{l}\text { job } \\
\text { dissatisfaction }\end{array}$ & $\begin{array}{l}\text { definicji nie podano; } \\
\text { operacjonalizacja: } \\
\text { trzy pytania ankietowe: } \\
\text { "All in all, I am very } \\
\text { satisfied with my } \\
\text { current job" } \\
\text { "If I had to decide all } \\
\text { over again whether to } \\
\text { take my job, I would" } \\
\text { "Thinking about your } \\
\text { job on the whole are } \\
\text { you very satisfied, } \\
\text { somewhat satisfied, } \\
\text { somewhat dissatisfied, } \\
\text { very dissatisfied" }\end{array}$ & $\begin{array}{l}\text { personal } \\
\text { Internet } \\
\text { use } \\
\text { during } \\
\text { work }\end{array}$ & $\begin{array}{l}\text { definicji nie podano; } \\
\text { operacjonalizacja: dwa } \\
\text { pytania ankietowe: } \\
<<\text { respondents } \\
\text { indicated how often } \\
\text { they use a computer } \\
\text { during work } \\
\text { "for personal email } \\
\text { and text messaging" } \\
\text { and "to look up } \\
\text { information of } \\
\text { personal interest, such } \\
\text { as news, sports scores, } \\
\text { or stock reports">> }\end{array}$ & nie \\
\hline $\begin{array}{l}\text { Garrett } \\
\text { and } \\
\text { Danziger } \\
(2008)\end{array}$ & $\begin{array}{l}\text { ankieta telefoniczna, } \\
\text { USA, } 1024 \\
\text { respondentów } \\
\text { zatrudnionych } \\
\text { w przedsiębiorstwach }\end{array}$ & $\begin{array}{l}\text { H2: Increasing } \\
\text { job stress is } \\
\text { associated with } \\
\text { higher levels } \\
\text { of personal } \\
\text { Internet use } \\
\text { during work. }\end{array}$ & job stress & $\begin{array}{l}\text { definicji nie podano; } \\
\text { operacjonalizacja: } \\
\text { Trzy pytania } \\
\text { ankietowe: } \\
\text { "I never seem to have } \\
\text { enough time to get my } \\
\text { job done" } \\
\text { "There is too much } \\
\text { stress in my job" } \\
\text { "My job demands too } \\
\text { much of me" }\end{array}$ & $\begin{array}{l}\text { personal } \\
\text { Internet } \\
\text { use } \\
\text { during } \\
\text { work }\end{array}$ & jw. & nie \\
\hline
\end{tabular}

Analiza tekstów opartych na metodach jakościowych jest zdecydowanie trudniejsza. W takich publikacjach znacznie trudniej jest oddzielić wyniki („Results”)

1 Jeśli sporządzamy SPL by potem na tej podstawie opracować metaanalizę powinniśmy na tym etapie wynotować również wartości korelacji. Najprościej jest to zrobić kopiując całą tabelę 1 (correlation matrix) do pliku Excel. 
od dyskusji („Discussion”), ponieważ bardzo często są one oparte na założeniu, że zebrany materiał empiryczny wymaga interpretacji (Burrell i Morgan, 1979). W przypadku tego rodzaju tekstów należy skupić się na analizie sekcji „Discussion”. Jednocześnie pamiętajmy, że siłą metody SPL jest możliwość uwzględnienia badań jakościowych, które są pomijane w metaanalizach. Dlatego eliminacja badań jakościowych ze SPL nie jest dobrym pomysłem, nawet jeśli ich analiza nastręcza dodatkowych problemów.

\section{Tworzenie konceptualnej mapy badań}

Spora część SPL publikowanych w naukach o zarządzaniu stawia sobie za cel stworzenie swego rodzaju konceptualnej mapy dotychczasowych badań (np. (Dabić i in., 2020)). Chcemy się dowiedzieć, jakie paradygmaty teoretyczne, pytania badawcze, konstrukty, instrumenty pomiarowe, metody są stosowane w badaniach nad interesującą nas tematyką. Przygotowanie takiego typu SPL jest trudniejsze, ponieważ nie może ograniczyć się do mechanicznego kopiowania hipotez, operacjonalizacji itd. Taki SPL przygotowujemy, posługując się metodami analizy treści. Szczególnie przydatne będzie kodowanie in vivo, to jest identyfikacja kodów pojawiających się podczas lektury tekstów (Hensel i Glinka, 2012). Analizę tego typu znacznie ułatwia zastosowanie aplikacji służących analizie jakościowej, na przykład Atlas.ti. Aplikacja umożliwia automatyczne zaimportowanie źródeł z menedżera literatury, co pozwala na znaczną oszczędność czasu.

Czytamy każdy z tekstów, tworząc jednocześnie kody, które pozwolą nam zagregować rezultaty wszystkich badań. Przykład stosowania narzędzia w SPL sporządzonym do doktoratu można znaleźć w Lewis (2016).

Dobre omówienie podstaw analizy literatury z wykorzystaniem tej aplikacji można znaleźć pod adresami:

https://atlasti.com/2017/02/09/lit-reviews/

https://atlasti.com/2016/09/01/litreview/

\subsection{Analiza trafności badania}

Dla rezultatów SPL istotna jest nie tylko analiza wyników raportowanych w odnalezionych tekstach, lecz także ocena trafności badań, które odnaleźliśmy. Badanie może oferować bardzo atrakcyjne rezultaty, ale jeśli zostało przeprowadzone w sposób wadliwy, to nie powinniśmy do tych rezultatów przywiązywać specjalnej wagi w raporcie z SPL.

Trafność badania można zdefiniować jako stopień, w jakim rezultaty badania odpowiadają badanej rzeczywistości (Shadish, Campbell i Cook, 2001). Sposób 
realizacji badania empirycznego może narażać je na wystąpienie zagrożeń dla trafności. Zagrożenia dla trafności badania można zdefiniować jako czynniki, które powodują, że wyniki badania nie w pełni (lub wcale) odpowiadają badanej rzeczywistości. Wszystkie badania prowadzone w ramach nauk społecznych są w pewnym stopniu niedoskonałe (Bono i McNamara, 2011). Celem analizy trafności jest stwierdzenie, czy ta niedoskonałość jest na tyle duża, że uniemożliwia uwzględnienie wyników badania w SPL. Poniżej omówię wybrane zagrożenia dla trafności badania, opierając się przede wszystkim na pracy Shadish i in. (2001). Osoby, zainteresowane prowadzeniem badań empirycznych powinny zapoznać się z całą książką, która nie tylko sumuje wiedzę na temat zagrożeń dla trafności badania, ale również jest napisana w taki sposób, że czyta się ją jak dobrą powieść detektywistyczną.

\subsubsection{Zagrożenia dla wewnętrznej trafności badania}

Badanie cechuje się wewnętrzną trafnością, jeśli zaobserwowana zależność jest zależnością przyczynowo-skutkową. Innymi słowy, istnieje mechanizm, który łączy zmienną niezależną ze zmienną zależną. Nie musimy znać kierunku tej zależności, możemy ograniczyć naszą hipotezę do stwierdzenia, że te dwie zmienne w pewien sposób ze sobą korelują. Jednak żebyśmy mogli twierdzić, że badanie cechuje się wewnętrzną trafnością musimy mieć pewność, że ta korelacja nie jest pozorna, tj., że nie zachodzi przypadkowo lub że nie jest skutkiem działania trzeciego czynnika, który kształtuje zarówno zmienną zależną, jak i niezależną.

Wybrane zagrożenia dla wewnętrznej trafności badania:

1. Zniekształcenie selekcji do grupy badanej i kontrolnej. Wpływ zmiennej niezależnej na zależną uda się stwierdzić tylko wtedy, gdy a) porównywane grupy pracowników, jednostek, przedsiębiorstw są identyczne (rzadki przypadek w naukach o zarządzaniu) lub b) jesteśmy w stanie uwzględnić różnice między badanymi grupami za pomocą zmiennej kontrolnej. Jeśli żadna z tych okoliczności nie zachodzi, to istnieje ryzyko, że badacz sformułuje błędny wniosek o odkryciu zależności, która w rzeczywistości nie istnieje. Przykład: porównując wynagrodzenia absolwentów najlepszych uczelni z wynagrodzeniami absolwentów gorszych uczelni zauważymy, że pierwsi zarabiają więcej, niż drudzy. Czy można na tej podstawie wnioskować, że to edukacja na prestiżowej uczelni spowodowała wyższe wynagrodzenie? Niekoniecznie. Być może za wyższe wynagrodzenia odpowiadają inne czynniki. Przykładowo, osoby studiujące na najlepszych uczelniach pochodzą z bardziej zamożnych rodzin niż te studiujące na gorszych uczelniach. Wysokie zarobki mogą wynikać z kontaktów, którymi dysponują rodzice absolwentów najlepszych uczelni, a nie z tego, że czegoś się podczas studiów nauczyli. W systemach 
o bardzo ostrej selekcji na studia (np. w systemie USA), studenci najlepszych uczelni mają po prostu wyższe kompetencje poznawcze, niż studenci mniej prestiżowych uczelni zatem prawdopodobnie uzyskaliby wyższe wynagrodzenia, nawet gdyby studiowali na gorszych uczelniach.

2. Wystąpienie innych zdarzeń, które mogły wywołać badany efekt. Zagrożenie wnioskowania o istnieniu zależności przyczynowo-skutkowej może wynikać z wystąpienia czynników, których badacz nie uwzględnił wśród zmiennych kontrolnych. Przykładowo, słynne badania w Hawthorne wykazały, że zainteresowanie sprawami pracownika zwiększa jego wyniki w pracy a świadomość uczestniczenia w eksperymencie wpływa na zachowania uczestników eksperymentu (Mayo, 1933; Roethlisberger i Dickson, 1941; Snow, 1927; Whitehead, 1938). Jednak ponowna analiza materiału zebranego podczas tych eksperymentów wskazuje, że równocześnie z badaniem wystąpiły liczne nieuwzględnione czynniki. Wybuchł Wielki Kryzys, który podniósł motywację do dobrej pracy, ponieważ pracownicy obawiali się zwolnienia (Franke i Kaul, 1978). Pracownicy skierowani do grupy eksperymentalnej wykonywali zadania w nielicznym zespole kilku osób, podczas gdy pracownicy w grupie kontrolnej wykonywali zadania w grupie ok. 100 osób. Wysokość wynagrodzenia była uzależniona od wyników całej grupy. Oczywiście w zespole liczącym 5 pracowników wpływ pojedynczego pracownika na rezultat grupy jest znacznie większy, więc ma on większą motywację do tego, by wydajnie pracować (Parsons, 1974).

3. Regresja do średniej. Jeśli jednostki do badania są dobierane na podstawie wcześniej uzyskanych wyników, to pojawia się zagrożenie zakłócenia wnioskowania przez regresję do średniej. Każdy pracownik, jednostka organizacyjna, przedsiębiorstwo mają pewien przeciętny poziom wyników. Jeśli w danym momencie uzyskali nadzwyczajnie wysoki wynik, to z czasem będą musieli uzyskać gorszy, tak by średnia została utrzymana. I odwrotnie: po gorszym wyniku często przychodzi lepszy. Te zmiany wyników są objawem naturalnej wariancji zachowań ludzi i organizacji. Zatem jeśli dobierzemy jednostki do grupy badanej na podstawie wysokich (niskich) wyników to z czasem te wyniki się pogorszą (poprawią), nawet jeśli badana przez nas interwencja nie wywołuje żadnych skutków. Przykładowo, jeśli w badaniu wpływu coachingu na wydajności menedżerów będziemy posługiwać się próbą osób, które zgłosiły się do programu coachingowego to może się okazać, że na skorzystanie z tej metody zdecydowały się osoby, które akurat odnotowały gorsze wyniki i dlatego postanowity szukać pomocy. Regresja do średniej spowoduje, że z czasem ich wyniki się poprawią, ale nie można na tej podstawie wnioskować, że poprawily się ze względy na uczestnictwo w programie coachingowym.

4. Dojrzewanie uczestników badania. Wraz z upływem lat ludzie, zespoły i organizacje dojrzewają, zyskując doświadczenie i wiedzę o wykonywanych zada- 
niach. Dlatego dwa pomiary rozdzielone pewnym przedziałem czasu pokażą nie tylko wpływ badanej interwencji, lecz również efekt dojrzewania. Przykładowo, jeśli porównamy wyniki testów studentów pierwszego roku studiów licencjackich $\mathrm{z}$ wynikami studentów ostatniego roku studiów magisterskich, to rezultat tego porównania pokaże nie tylko przyrost wiedzy, którą sprawdza test, ale również przyrost wiedzy na temat zdawania testów.

5. Utrata/,,wymieranie” uczestników badania. W badaniach podłużnych zawsze musimy się liczyć z niebezpieczeństwem tego, że część osób i organizacji, które wzięły udział w pierwszym etapie badania zrezygnuje lub $\mathrm{z}$ innych powodów zostanie wykluczona $\mathrm{z}$ dalszych etapów badania. Jeśli to zjawisko ma charakter losowy, tj. każdy uczestnik badania ma takie samo prawdopodobieństwo odpadnięcia z próby, to nie wystąpi zagrożenie dla wewnętrznej trafności badania. Jeśli jednak utrata następuje ze względu na badaną cechę, to mamy do czynienia z poważnym zagrożeniem dla trafności badania. Przykładowo, ponowne analizy wspomnianego wcześniej badania w Hawthorne pokazują, że wzrost przeciętnych rezultatów uzyskiwanych przez grupę badaną wynikał w dużym stopniu z tego, że pracownicy, którzy gorzej wykonywali swoje zadania zostali wykluczeni z grupy, a na ich miejsce wprowadzono bardzo wydajnych pracowników. Zatem wzrosty wydajności nie wynika z zainteresowania sprawami pracowników, lecz ze zmiany składu osobowego grupy badanej (Franke \& Kaul, 1978). Podobne zagrożenie - choć rzadko kiedy wynikające z działań podejmowanych przez badacza - występuje wtedy, gdy badamy wyniki pewnej grupy przedsiębiorstw, zapominając o tym, że część $\mathrm{z}$ nich zbankrutowała i dlatego nie bierze udziału w kolejnych etapach badania (pomiarach). Na tej podstawie możemy błędnie wnioskować, że pewna interwencja zwiększa wyniki przedsiębiorstw, choć gdybyśmy uwzględnili wyniki przedsiębiorstw, które zbankrutowały ten wniosek byłby nieuzasadniony.

6. Zmiana instrumentu pomiarowego. Wyniki pomiarów przeprowadzonych w różnych punktach czasu (przed wystąpieniem badanej interwencji i po) są porównywalne tylko wtedy, gdy w każdym przypadku są wykonywane za pomocą tego samego narzędzia pomiarowego. Jeśli narzędzie pomiarowe się zmieni, to zarejestrowana zmiana w poziomie pomiaru może wynikać ze zmiany narzędzia a nie z interwencji (np. wdrożenie nowego systemu logistycznego). Przykład: badamy wyniki przedsiębiorstw, odnosząc je do indeksu giełdowego. W trakcie realizacji badania autorzy indeksu zmieniaja portfel akcji, na podstawie którego obliczany jest indeks. Indeks sporządzony na podstawie nowego portfela może (ale nie musi) w inny sposób odzwierciedlać kondycję giełdy. 


\subsubsection{Zagrożenia dla zewnętrznej trafności badania}

Zewnętrzna trafność badania to wnioskowanie o tym, na jakie populacje, warunki, zmienne i miary można generalizować uzyskane rezultaty (Campbell \& Stanley, 1963). Zagrożenia dla zewnętrznej trafności badania to czynniki, które powodują, że generalizacja wyników badania będzie nieuzasadniona (Shadish i in., 2001). Należy pamiętać o tym, że prawdziwy zakres generalizacji można określić dopiero, gdy porównamy wyniki analizowanego badania $\mathrm{z}$ wynikami innych studiów na ten sam temat (Busse, Kach i Wagner, 2017; Greenberg, 1987; McGrath i Brinberg, 1983). Jednak podczas analizy publikacji wchodzących w skład SPL powinniśmy zwracać uwagę na cechy badania, które mogą sugerować, że mamy do czynienia z zagrożeniem dla zewnętrznej trafności. Jednocześnie należy pamiętać o tym, że w naukach o zarządzaniu właściwie wszystkie rezultaty badań są — w mniejszym lub większym stopniu — narażone na występienie zagrożeń tego typu. Jest tak za sprawą ogromnej różnorodności typów organizacji oraz zachowań i procesów zachodzących w ich wnętrzu.

1. Zaobserwowana zależność może nie występować $w$ przypadku jednostek o innych cechach. Świat organizacji jest niezwykle różnorodny, co zdecydowanie utrudnia generalizację wyników. Rezultaty uzyskane w badaniu dużych przedsiębiorstw nie zawsze można generalizować na małe przedsiębiorstwa. Wyniki dotyczące pracy menedżerów w branżach wysokiej technologii niekoniecznie są generalizowalne na menedżerów restauracji. Badania prowadzone na studentach kursów MBA niekoniecznie mogą być generalizowane na wszystkich menedżerów, ponieważ można podejrzewać, że osoby, które trafiają na takie kursy stanowią specyficzną podgrupę wszystkich menedżerów. Określając generalizowalność wyników powinniśmy zawsze zastanowić się czy specyficzne cechy badanych jednostek (takie jak wielkość, profil pracy, uczestnictwo w programie) mogą wpływać na wyniki badania.

2. Zależność zaobserwowana przy pewnym poziomie interwencji może nie występować przy innych poziomach interwencji. Jedno z zagrożeń dla zewnętrznej trafności badania jest związane z formą badanej interwencji. Jeśli wyniki badania wskazują, że stosowanie metod Six Sigma przynosi dobre rezultaty, gdy jest połączone z odpowiednim systemem wynagradzania, to nie wiadomo czy takie same rezultaty uzyskamy, gdy system wynagradzania nie jest dopasowany do wymogów Six Sigma.

3. Zależność zaobserwowana dla jednego rezultatu może nie występować w przypadku innych rezultatów. Wyniki uzyskiwane przez ludzi, zespoły i organizacje są na ogół wielowymiarowe. Dlatego należy zadawać pytanie, czy zależność z jednym wymiarem czy sposobem pomiaru wyniku może być generalizowana na inne wymiary. Przykładowo, w badaniach strategii przedsiębiorstw wykorzystuje się ponad 200 różnych miar wyników (Rich- 
ard, Devinney, Yip i Johnson, 2009). Jednak poszczególne miary wyników słabo ze sobą korelują (Combs, Crook i Shook, 2005), a zależności między nimi zmieniają się w czasie (Fryxell i Barton, 1990; Steers, 1975). Dlatego nie można bezrefleksyjnie generalizować rezultatów uzyskanych dla jednych miar wyników, na inne.

4. Zależność zaobserwowana w danym kontekście może nie występować w innych kontekstach. Jednym z najważniejszych źródeł zagrożeń dla zewnętrznej trafności badania jest wpływ kontekstu. Ludzie i organizacje zawsze działają w jakimś kontekście, który mocno determinuje ich zachowania. Kultura narodowa (Adler, Doktor i Redding, 1986; Chen, Leung i Chen, 2009; Cheng, 1994), warunki makroekonomiczne panujące w chwili przeprowadzania badania (Cappelli i Sherer, 1991), instytucje i system prawa (Fainshmidt, Judge, Aguilera i Smith, 2018; Zhu i Chung, 2014), język czy branża, mogą determinować uzyskane rezultaty. Niestety, badacze organizacji rzadko kiedy uwzględniają wpływ otoczenia (Bamberger, 2008; Brutus, Aguinis i Wassmer, 2013; Johns, 2017, 2018; Rousseau i Fried, 2001), co często uniemożliwia generalizowanie rezultatów.

\subsubsection{Zagrożenia dla trafność konstruktów}

Pomiary prowadzone w badaniach empirycznych rzadko kiedy są interesujące same w sobie. Jeśli prosimy pracowników pewnego przedsiębiorstwa o wypełnienie ankiety z pytaniami o poziom satysfakcji z wynagrodzenia czy relacji interpersonalnych $\mathrm{w}$ przedsiębiorstwie, to przeważnie naszym podstawowym celem nie jest stwierdzenie, co badani odpowiadają na te pytania. Celem jest pomiar pewnego konstruktu: satysfakcja z warunków pracy. Zagrożenia dla trafności konstruktów dotyczą relacji konstrukt - badana rzeczywistość. Liczba zagrożeń dla trafności konstruktów jest bardzo długa - Shadish i in. (2001) wymieniają 14 typów takich zagrożeń. Poniżej omawiam cztery podstawowe.

1. Błędna/niewystarczająca konceptualizacja konstruktu. W wielu studiach badany konstrukt nie jest jednoznacznie zdefiniowany, ponieważ autor przyjmuje, że znaczenie konstruktu jest oczywiste (por. tabela $2 \mathrm{w}$ sekcji 5.3). $\mathrm{W}$ innych przypadkach konstrukt jest zdefiniowany zbyt szeroko lub zbyt wąsko. Jednak podstawowym problemem nauk społecznych jest to, że konstrukty są znacznie mniej oczywiste, niż w naukach ścisłych. Przykładowo, jest jasnym, że ciężar stanowi obiektywnie istniejącą właściwość każdego ciała, która może być poddana badaniom. Wiadomo również, jak ten konstrukt mierzyć. Problemem może być jedynie precyzja pomiaru. W naukach społecznych mało jest takich oczywistych przypadków. Czy istnieje coś takiego, jak wynik przedsiębiorstwa? Można się różnie zapatrywać na tę kwestię, a z tych różnic wynikają różnice w stosowanych metodach pomiaru (Miller, 
Washburn i Glick, 2013), które z kolei wpływają na kierunek i znak zidentyfikowanej zależności przyczynowo-skutkowej.

2. Błędny dobór operacjonalizacji konstruktu. Operacjonalizacja konstruktu mierzy inne zjawiska oprócz konstruktu albo nie mierzy badanego konstruktu albo inny konstrukt lepiej wyjaśniałby zaobserwowane zjawisko. Przykładowo, badacz chce stwierdzić czy pracownicy zatrudnieni w przedsiębiorstwie od niedawna w tym samym stopniu identyfikują się ze strategią przedsiębiorstwa, co pracownicy z dłuższym stażem pracy. Jako operacjonalizację tego konstruktu przyjmuje staż pracy. Jednak w związku z tym, że większość pracowników z krótkim stażem pracy to ludzie młodzi, w rzeczywistości mierzy wpływ wieku lub wpływ wprowadzonej niedawno reformy edukacji lub wpływ postaw charakterystycznych dla pokolenia, do którego należą młodzi pracownicy, a nie wpływ stażu pracy.

3. Poleganie na jednym narzędziu pomiaru powoduje, że mierzymy jednocześnie badany konstrukt i wpływ metody. Problem często występujący w badaniach ankietowych, w których wszystkie informacje zostały zebrane za pomocą jednego narządzenia. Można podejrzewać, że gdyby część informacji zebrano z innych źródeł to rezultat badania byłby inny. Problem występuje również wtedy, gdy zawsze w ten sam sposób przeprowadzamy interwencję. Przykładowo, jeśli prezentujemy badanym pewne rekomendacje ekspertów na piśmie, a następnie mierzymy czy się do nich stosują, to nie możemy być pewni, czy rezultat badania byłby taki sam, gdyby te rekomendacje zostały przedstawione w formie dźwiękowej lub nagrania wideo (Shadish i in., 2001).

4. Ograniczenie zakresu interwencji uniemożliwia wnioskowanie o skutkach wszystkich zakresów interwencji. W niektórych badaniach uzyskane zostają nieuzasadnione wnioski, ponieważ konstrukt zostaje utożsamiony z pewnym specyficznym i ograniczonym zakresem interwencji. Przykładowo, badani zostali poddani jednogodzinnej sesji coachingu miesięcznie i na tej podstawie badacz dochodzi do wniosku, że te sesje nie powodują zmiany w wynikach menedżerów. Nie można na tej podstawie wnioskować o skuteczności coachingu w ogóle, można jedynie wnioskować o skuteczności coachingu definiowanego jako „trwająca jedną godzinę rozmowa coachingowa raz w miesiącu".

\subsubsection{Zagrożenia dla trafności inferencji statystycznej}

Narzędzia wnioskowania statystycznego wykorzystywane w badaniach empirycznych mają na celu stwierdzenie czy zależność między zmiennymi istnieje, jaki jest jej kierunek i siła. Zagrożenia dla trafności inferencji statystycznej występują wtedy, gdy zastosowane metody statystyczne prowadzą nas do błędnych lub nieuzasadnionych wniosków (Shadish i in., 2001). 
Wybrane zagrożenia dla trafności inferencji statystycznej:

1. Niska siła statystyczna testu. Siła statystyczna mówi o zdolności testu do odkrycia zależności między konstruktami. Ujmując rzecz bardziej precyzyjnie, jest to prawdopodobieństwo, że odrzucimy hipotezę zerową (brak zależności), gdy jest ona fałszywa (Shadish i in., 2001). Niska siła statystyczna powoduje, że wnioskujemy o braku zależności, pomimo że zależność występuje (Cohen, 1965). Niewystarczająca siła testów jest poważnym problemem w wielu dyscyplinach nauki. Przykładowo, w badaniach psychologicznych jedynie $8 \%$ testów cechuje się wystarczającą siłą (Stanley, Carter i Doucouliagos, 2018)2. Obliczenie siły statystycznej jest zadaniem złożonym, a wzór służący tym obliczeniom zależy od tego, jaki test statystyczny został wykorzystany w badaniu. Kalkulatory siły statystycznej testu można znaleźć pod adresem: http://powerandsamplesize.com/Calculators/

2. Naruszenie założeń testu statystycznego. Przykładowo ANOVA zakłada, że obserwacje są niezależne, tj. nie istnieje ukryty czynnik, które powoduje podobieństwo zachowań/wyników dla grupy badanej i kontrolnej. Bardzo łatwo jest złamać to założenie, na przykład ankietując badanych z tylko jednego przedsiębiorstwa. Jest prawdopodobne, że osoby zatrudnione w tym samym przedsiębiorstwie, mają pewien zbiór wspólnych cech, na przykład ukończyły studia o podobnym profilu albo mają podobne profile osobowości.

3. $\boldsymbol{P}$-hacking i HARKing. Od kilkudziesięciu lat naukowcy zadają sobie pytanie, jak jest możliwe, że większość opublikowanych testów istotności statystycznej daje pozytywne wyniki (Sterling, 1959). Co więcej, w naukach społecznych, a w szczególności w psychologii, ekonomii i naukach o biznesie wyników pozytywnych jest znacznie więcej niż w naukach przyrodniczych (Fanelli, 2010). Za te zaskakujące wyniki odpowiada powszechne (Bedeian, Taylor i Miller, 2010; Tourish i Craig, 2020) stosowanie $p$-hackingu i HARKingu. $\boldsymbol{P}$-hacking (Simmons, Nelson i Simonsohn, 2011) to naciąganie wartości testu istotności statystycznej ( $p$ ) poprzez: wyłączanie/włączanie wyników skrajnych (outliers), dodawanie/usuwanie zmiennych kontrolnych, poszukiwanie dodatkowych danych by osiagnąć istotność statystyczną oraz raportowanie tylko tych testów, które dały pozytywny rezultat. HARKing (Hypothesizing After the Results are Known) to stawianie hipotez po przeprowadzeniu badania (Kerr, 1998). Badacze stosujący HARKing najpierw korelują wszystkie zmienne ze sobą, następnie znajdują te, które uzyskały „istotność statystyczną" i dopiero potem stawiają hipotezy. To odwrócenie kolejności etapów procedury (powinniśmy najpierw stawiać hipotezy, a dopiero potem

2 Autorzy przyjęli jako punkt krytyczny zalecenie sformułowane przez Coehna (1965): test ma wystarczającą siłę, jeśli występuje $80 \%$ prawdopodobieństwo, że zostanie wykryta zależność, która istnieje. 
je testować) stanowi złamanie podstawowej logiki testu. Obliczona w ten sposób „istotność” jest znacznie zawyżona - przy przeprowadzeniu odpowiednio dużej liczby testów istotności zawsze uzyskamy choć kilka wyników pozytywnych, nawet jeśli zależność między korelowanymi zmiennymi nie istnieje (Ames \& Reiter, 1961). Badacz, który stosuje wielokrotne testy w poszukiwaniu ,istotności” powinien zastosować poprawkę Bonferroniego, czyli podzielić kryterium istotności $(p<0,05 ; p<0,01)$ przez liczbę przeprowadzonych testów. Ostatnio twierdzi się nawet, że powinniśmy odejść od testowania istotności hipotezy zerowej jako podstawowego narzędzia wnioskowania statystycznego (Amrhein, Gelman, Greenland i McShane, 2019; Amrhein, Greenland i McShane, 2019; Orlitzky, 2011; Schwab, Abrahamson, Starbuck i Fidler, 2011).

4. Niska rzetelność miar. Wniosek co do istnienia zależności między zmiennymi może zostać zniekształcony również przez niską rzetelność miar. Jeśli miara opiera się na jednym lub kilku pytaniach ankietowych, które w dodatku nie zostały wcześniej przetestowane, to możemy obawiać się, że jej rzetelność jest niska. Jeśli w kodowaniu dedukcyjnym (przed rozpoczęciem kodowania tworzona jest książka kodów) tylko jeden badacz koduje wszystkie przypadki i w związku z tym nie obliczono wskaźników zgodności ocen (inter-rater agreement, Morrissey (1974)) to również możemy spodziewać się niskiej rzetelności pomiaru. Niska rzetelność miar osłabia zależność między dwiema zmiennymi, natomiast w przypadku trzech i więcej zmiennych może zarówno osłabiać, jak i wzmacniać siłę zależności (Shadish i in., 2001).

5. Brak/niska standaryzacja interwencji/bodźca. Wnioskowanie o zależności między zmiennymi może być również zniekształcone, jeśli różni uczestnicy badania (jednostki, grupy, organizacje) otrzymują różną „dawkę” interwencji. Wydaje się być to szczególnie poważne wyzwanie w naukach o zarządzaniu, które często studiują skutki technik i rozwiązań organizacyjnych, nad którymi badacz nie ma żadnej kontroli. Jeśli część organizacji wprowadziła wszystkie elementy pewnej metody zarządzania, a inne zaimplementowały tylko część z nich, to wynik wnioskowania zostanie zaburzony. Jeśli niektóre organizacje stworzyły jedynie pozory wprowadzenia pewnej metody zarządzania (ponieważ tego oczekuje otoczenie) (Hensel, 2017, 2018b), a badacz nie będzie zdawał sobie sprawy z pozorności wdrożenia, to również popełni błąd we wnioskowaniu.

\subsubsection{Zagrożenia dla trafności fasadowej (zdroworozsądkowej)}

Ostatnim elementem oceny trafności badania jest zdroworozsądkowa ocena trafności. Czytając rezultaty badania, zadajemy sobie pytanie, czy wydają się one możliwe, zgodne z naszą wiedzą o świecie. Przykładowo, w badaniach psycho- 
logicznych notujemy w ostatniej dekadzie przełom w podejściu do $p$-hackingu $\mathrm{i}$ innych wątpliwych metod badawczych. Ten przełom został spowodowany publikacją tekstu, w którym „udowodniono” istnienie prekognicji (przewidywanie przyszłości) (Bem, 2011). Dla psychologów był to wyraźny sygnał, że coś jest nie tak $\mathrm{w}$ badaniach i procesie publikacyjnym $\mathrm{w}$ psychologii. W naukach o zarządzaniu rzadko spotkamy się $\mathrm{z}$ wynikami $\mathrm{w}$ aż tak dużym stopniu niezgodnymi ze zdrowym rozsądkiem, jednak i w tej dziedzinie często pojawiają się wyniki, w które należy powątpiewać. Jednocześnie należy zachować umiar w kierowaniu się zdrowym rozsądkiem. Liczne badania pokazują, że naukowcy są bardziej skłonni uznać za wątpliwe te wyniki, które są niezgodne z ich światopoglądem i przekonaniami. Na przykład, zwolennicy założenia mówiącego, że człowiek jest tabula rasa i w związku z tym jego zachowania mogą być dowolnie kształtowane na ogół ignorują wpływ genów na zachowania (Pinker, 2003; Plomin, 2019). Zwolennicy determinizmu biologicznego ignorują jednak wpływ czynników środowiskowych (społecznych, ekonomicznych, politycznych).

Niektóre symptomy niskiej trafności fasadowej badania:

1. Mała interwencja, olbrzymi skutek. Wiele bestsellerów dotyczących zarządzania sugeruje, że istnieją niezawodne sposoby na skuteczne zarządzanie, co więcej są one proste i ich stosowanie nie wymaga wielkiego wysiłku. Jeśli praca stwierdza, że istnieją niewielkie interwencje dające duże rezultaty, to powinniśmy powątpiewać w trafność takiego badania. Wyjątek stanowią przypadki, w których interwencja jest przedstawiana jako łatwa do wdrożenia, choć w rzeczywistości trudno ją zaimplementować. Przykładowo, bez wątpienia podejmowanie trafnych decyzji sprzyja dobrym wynikom przedsiębiorstwa. Niestety, znaczniej łatwiej napisać „powinieneś podejmować trafne decyzje" niż takie decyzje podejmować w rzeczywistości.

2. Olbrzymia interwencja, brak skutku. $Z$ odwrotnym przypadkiem mamy do czynienia wtedy, gdy autorzy dowodzą, że szeroko zakrojone działania nie przynoszą żadnych rezultatów. Oczywiście takie przypadki się zdarzają, jednak można podejrzewać, że częściej mamy do czynienia z sytuacją, w której duża interwencja przynosi skutek, lecz autorzy badania nie umieli go zmierzyć lub nie jest to ten skutek, który był celem interwencji.

3. Wszystkie poprzednie badania pokazały brak zależności lub przeciwny kierunek zależności. Naszą podejrzliwość powinny również budzić rezultaty całkowicie sprzeczne z wcześniejszymi wynikami. Oczywiście, takie rezultaty się zdarzają. Przykładowo, niedawna próba replikacji 100 badań z zakresu psychologii społecznej i poznawczej pokazała, że jedynie około $36 \%$ wyników udało się uzyskać ponownie (Collaboration, 2015). Pamiętajmy też o tym, że rezultaty sprzeczne z wcześniejszą wiedzą są uznawane za najciekawsze (Davis, 1971) i mogą prowadzić do przełomu w badaniach. Jednak tego 
rodzaju wyniki są stosunkowo rzadkie, więc powinniśmy przyglądać im się ze zdwojoną podejrzliwością.

4. Brak uzasadnienia teoretycznego dla odnalezionej zależności. Wątpliwości powinny też budzić wyniki, dla których nie istnieje uzasadnienie teoretyczne. Jest bardzo prawdopodobne, że odkryta zależność jest wynikiem prowadzenia wielu testów na wielu zmiennych (patrz sekcja 5.4.4.). Być może odnaleziona zależność nie jest przypadkowa, ale powinniśmy poczekać z jej zaakceptowaniem do momentu, w którym kolejni badacze udowodnią istnienie mechanizmu przyczynowo-skutkowego łączącego badane zmienne.

Po przeprowadzeniu analizy trafności każdego z odnalezionych badań powinniśmy je zanotować, na przykład w tabeli (3), która stanowi rozszerzenie tabeli opracowanej podczas analizy wyników (tabela 2, sekcja 5.3). W związku z tym, że zagrożenia dla trafności badania na ogół dotyczą całego badania a nie poszczególnych hipotez (choć istnieją wyjątki od tej reguły), możemy analizę zagrożeń wykonać jednokrotnie dla całego badania. Poziom trafności możemy oznaczać, przyznając punkty (np. 1-niska trafność, 3-wysoka), jednak pamiętajmy, że nie jest dobrym pomysłem sumowanie tych wartości by określić całkowitą trafność badania (Valentine, 2019). Niektóre zagrożenia dla trafności występują powszechnie (np. zagrożenia dla trafności zewnętrznej) i nie dyskwalifikują rezultatów badania. Inne zagrożenia (np. dla trafności wewnętrznej) mogą całkowicie podważać wyniki. Ujmując rzecz inaczej: nie jest tak, że wysoka trafność konstruktów może zrekompensować niską trafność inferencji statystycznej albo że wysoka trafność inferencji może zrekompensować niską trafność wewnętrzną. Oceny punktowe są jedynie informacją, której autor użyje przy pisaniu końcowego raportu z SPL.

Tabela 3. Analiza zagrożeń dla trafności badania. Rozwinięcie tabeli z sekcji 5.3.

\begin{tabular}{|c|c|c|c|c|c|c|}
\hline \multicolumn{2}{|r|}{ Tabela 2} & $\begin{array}{l}\text { Tabela } 3 . \\
\text { Trafność... }\end{array}$ & \multirow[b]{2}{*}{ zewnętrzna } & \multirow[b]{2}{*}{ konstruktów } & \multirow[b]{2}{*}{$\begin{array}{l}\text { inferencji } \\
\text { statystycznej }\end{array}$} & \multirow[b]{2}{*}{ fasadowa } \\
\hline Badanie & Hipoteza & wewnętrzna & & & & \\
\hline $\begin{array}{l}\text { Garrett } \\
\text { and } \\
\text { Danziger } \\
(2008)\end{array}$ & $\begin{array}{l}\text { H1: } \\
\text { Increasing job } \\
\text { dissatisfaction is } \\
\text { associated with } \\
\text { higher levels } \\
\text { of personal } \\
\text { Internet use } \\
\text { during work. }\end{array}$ & 3 & 2 & 1 & 3 & 3 \\
\hline
\end{tabular}




\section{Rozdział 6 \\ Przygotowanie raportu z systematycznego przeglądu literatury}

Ostatnim etapem przygotowania przeglądu jest opracowanie raportu. Jego kształt będzie zależał od celu, w którym sporządzono przegląd. Jeśli sporządziliśmy SPL jako podstawę badania własnego, to od naszego wyboru zależy czy i w jaki sposób zaraportujemy wyniki. Niewykluczone, że zdecydujemy się na zreferowanie wyników przeglądu tak, jakby został sporządzony za pomocą metod przeglądu narracyjnego - w ten sposób unikniemy konieczności sprawozdawania metody, którą wykorzystaliśmy do przygotowania SPL.

Jeśli chcemy by rezultat naszej pracy został wydany jako samodzielna publikacja raportująca wyniki systematycznego przeglądu literatury, to powinniśmy postępować zgodnie z konwencją przyjętą w danym środowisku badaczy. Zwolennicy metody SPL często zachęcają do raportowania wyników zgodnie z formatem PRISMA (Preferred Reporting Items for Systematic Reviews and MetaAnalyses) (Moher, Liberati, Tetzlaff, Altman i PRISMA Group, 2009). Na ten format składają się dwa elementy: PRISMA checklist (lista kontrolna) obejmująca 27 pól/informacji, które należy zakomunikować w końcowym raporcie oraz diagram PRISMA, informujący czytelnika, ile badań trafiło do każdego z etapów analizy (rysunek 1). Diagram wypełniamy, posługując się informacji zebranymi w tabeli $1 \mathrm{w}$ sekcji 5.2. 
Rysunek 1. Diagram PRISMA. Opracowano na podstawie Moher i in. (2009)

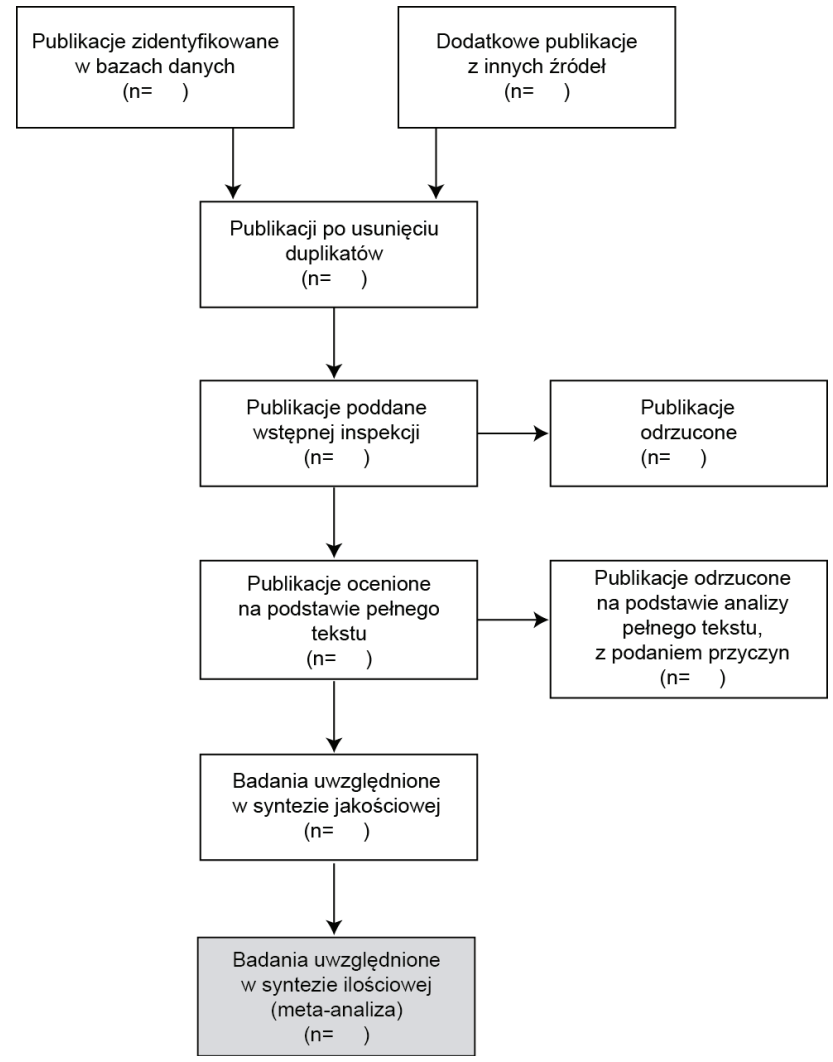

Jednak ta konwencja nie do końca jest przestrzegana w naukach o zarządzaniu. O ile diagram PRISMA (lub wariacja na jego temat) jest często zamieszczany w raportach z SPL, o tyle sama treść raportu nie zawsze w stu procentach jest zgodna z listą kontrolą PRISMA. Zwróćmy uwagę, że ostatni element diagramu PRISMA („badania uwzględnione w syntezie ilościowej (metaanaliza)”) uwzględniamy tylko wtedy, gdy rzeczywiście raportujemy wyniki metaanalizy.

W raporcie z SPL powinny znaleźć się co najmniej następujące elementy:

1. Przyczyna i cel sporządzenia SPL oraz pytania badawcze. Należy unikać uzasadnień w rodzaju „temat wydał nam się ciekawy”. Uzasadnieniem powinna być potrzeba teoretyczna/empiryczna/praktyczna oraz brak SPL na dany temat. Należy również zwrócić uwagę, że różne typy SPL są uzasadnione różnymi przesłankami. Przykładowo, SPL na temat zależności między outsourcingiem a wynikami może być uzasadnione potrzebą praktyczną, to jest koniecznością dostarczenia wiedzy dla praktyków (zgodnie z duchem evidence-based management (Pfeffer i Sutton, 2006; Rousseau, 2012a)), podczas 
gdy SPL na temat imitacji raczej będzie uzasadniony chęcią doskonalenia teorii.

2. Opis metody. Zdecydowanie najważniejszym elementem SPL, który odróżnia ten typ przeglądu literatury od innych jest dokładny i transparentny opis metody. Powinna ona być opisana na tyle precyzyjnie, by inni badacze mogli łatwo powtórzyć całą procedurę. Dlatego należy wskazać wszystkie źródła, w których przeprowadzono wyszukiwanie (np. Web of Science, SCOPUS), sposób przeszukiwania (czy wyniki zapytań do baz bibliograficznych zostały wzbogacone dzięki zastosowaniu metody kuli śnieżnej) i kryteria wyszukiwania. W wielu wypadkach podaje się również ciąg wyszukiwania (zapytanie do bazy bibliograficznej). Typowa sekcja raportu opisująca metodę przyjmuje następującą postać:

„Przeprowadziliśmy systematyczny przegląd literatury na temat wykorzystania Internetu w prywatnych celach w miejscu pracy (cyberloafing) (Lim, 2002). Na podstawie wstępnej analizy tekstów opublikowanych w okresie 1997-2020, odnaleźliśmy synonimy tego pojęcia ("cyberslacking”, "cyberdeviance”, "cyber deviance", "non-work-related computing", "workplace Internet leisure browsing", "Internet abuse", "workplace internet deviance", "personal use of the Internet”), które, razem z oryginalnym pojęciem („cyberloafing”) stanowiły podstawowe kryteria wyszukiwawcze. Szukaliśmy jedynie wyników badań empirycznych zatem z wyszukiwania wyłączyliśmy opracowania teoretyczne, teksty od redakcji, recenzje, systematyczne przeglądy tematu i metaanalizy oraz pisma, które publikują wyłącznie przeglądy literatury tematu. Nie nałożono ograniczeń na typ, rok i język publikacji. Wyszukiwanie przeprowadziliśmy w marcu 2020 roku w bazach Web of Science (236 rezultatów) i Scopus (323 rezultaty) [w przypisie podajemy ciąg wyszukiwania do WoS: TS= (cyberloafing OR cyberslacking OR cyberdeviance OR "cyber deviance" OR "non-work-related computing" OR "workplace Internet leisure browsing" OR "Internet abuse" OR "workplace internet deviance" OR "personal use of the Internet") NOT DT=(Book Review OR Editorial Material OR Discussion OR Letter OR Meeting Abstract OR Meeting Summary OR Review) NOT IS=(0363-7425 OR 1930-3807) oraz do Scopus: TITLE-ABS-KEY(cyberloafing OR cyberslacking OR cyberdeviance OR "cyber deviance" OR "non-work-related computing" OR "workplace Internet leisure browsing" OR "Internet abuse" OR "workplace internet deviance" OR "personal use of the Internet") AND NOT DOCTYPE(bz OR ed OR le OR no OR pr OR re) AND NOT ISSN(0363-7425 OR 1930-3807)].

Po eliminacji duplikatów, pozostało 346 publikacji, które trafiły do kolejnego etapu procedury [w tym miejscu na ogół umieszcza się odniesienie do diagramu PRISMA]. Analiza tytułów i abstraktów pozwoliła ograniczyć liczbę publikacji do 183. Analiza pełnego tekstu doprowadziła do ograniczenia liczby publikacji 
do 126. Te publikacje stanowią podstawę niniejszego systematycznego przeglądu literatury".

3. Wyniki przeglądu. Sposób referowania wyników zależy od typu i celu SPL. PRISMA zaleca omawianie rezultatów wszystkich badań indywidualnie i dopiero na tej podstawie tworzenie syntezy. Jednak w SPL w naukach o zarządzaniu autorzy przeważnie ograniczają się do przedstawienia syntetycznych rezultatów.

Pamiętajmy, że podstawową zasadą SPL jest uwzględnienie wszystkich wyników. Jeśli zatem wśród odnalezionych publikacji znajdziemy rezultaty przeczące sobie wzajemnie, to nie możemy omówić tylko wybranych z nich, lecz powinniśmy zaraportować wszystkie wątpliwości powstałe w wyniku rozbieżności w odnalezionych badaniach. Wyniki dotyczące poszczególne zależności odnalezionych w literaturze można zreferować w następujący sposób:

„Wyniki badań na temat wpływu postrzeganej surowości kary i postrzeganej pewności ukarania na odstraszanie od cyberloafingu są niejednoznaczne. Ankieta relacji między świadomością sankcji a intencją nadużywania zasobów IT wskazała, że postrzegana surowość sankcji ma negatywny wpływ na tę intencję (D’Arcy, Hovav i Galletta, 2009). Jednakże nie zaobserwowano takiego efektu dla pewności zastosowania sankcji. Podobne rezultaty uzyskano w innym badaniu ankietowym zrealizowanym na próbie 185 pracowników (Cheng i in., 2013). Te rezultaty są sprzeczne z wieloma badaniami pokazującymi, że to raczej pewność kary niż jej surowość odstrasza od popełniania wykroczenia (cyberloafowania) (Cheng, Li, Zhai i Smyth, 2014; D’Arcy i Devaraj, 2012; Henle i Blanchard, 2008; Herath i Rao, 2009; Khansa, Kuem i in., 2017; Li, Zhang i Sarathy, 2010; Paternoster, 1987).

Podsumowując, można stwierdzić, że dotychczasowe badania dostarczają mieszanych dowodów dotyczących wpływu kar na odstarszanie od cyberloafingu. Badacze nie zgadzają się co do tego, który aspekt karania (surowość czy pewność kary) wpływa na zachowania pracowników i czy taki wpływ w ogóle istnieje, choć ciężar dowodów sugeruje, że takie zjawisko występuje. Jednocześnie należy zauważyć, że wszystkie odnalezione badania z wyjątkiem dwóch były oparte na danych zebranych za pomocą kwestionariuszy ankietowych, co może sugerować niską trafność zewnętrzną (brak możliwości generalizowania wyników na rzeczywiste zachowania w organizacji) oraz niską trafność konstruktów (pomiar intencji cyberloafowania nie może być utożsamiany z pomiarem rzeczywistego cyberloafingu)" 1 .

1 Zaadaptowane z Hensel, P. G., i Kacprzak, A. (2020). Curbing cyberloafing: studying general and specific deterrence effects with field evidence. European Journal of Information Systems, doi:10.1080/0960085X.2020.1756701 
4. Lista źródeł. Raport powinien także zawierać listę badań, które zostały uwzlędnione w SLR. Popularnym rozwiązeniem jest oznaczenie w bibliografii (np. gwiazdką „,") źródeł, które przeanalizowano. Takie oznaczenie jest konieczne, ponieważ w bibliografii znajdą się również inne źródła, które posłużyły do uzasadnienia badania czy scharakteryzowania zastosowanych metod. 


\section{Rozdział 7}

\section{Narzędzia}

Posługiwanie się narzędziami informatycznymi do przeszukiwania, przechowywania i cytowania artykułów naukowych jest obecnie koniecznością, wynikającą z bardzo dynamicznego przyrostu liczby publikacji naukowych w ostatnich dekadach. W roku 2000 Web of Science indeksowało 60 periodyków naukowych zaliczonych do kategorii „management”. W roku 2018 był ich już 217. Rysunek 1 pokazuje liczbę artykułów naukowych publikowanych rocznie w pismach z tej kategorii. W sumie Web of Science przechowuje dane 750000 artykułów opublikowanych w pismach z kategorii „management”. Uwzględnienie kategorii pokrewnych („business”, „business, finance”) daje liczbę ponad 1200000 publikacji. Badania związane z tematyką istotną dla nauk o zarządzaniu publikowane są również w kategoriach „psychology” (ponad 1900000 publikacji) oraz „economics” (ponad 1000000 publikacji). W wymienionych kategoriach opublikowano łącznie prawie 4000000 tekstów $^{1}$.

Rysunek 1. Liczba artykułów publikowanych rocznie w kategorii „management” bazy Web of Science (dane pobrano 27.02.2020)

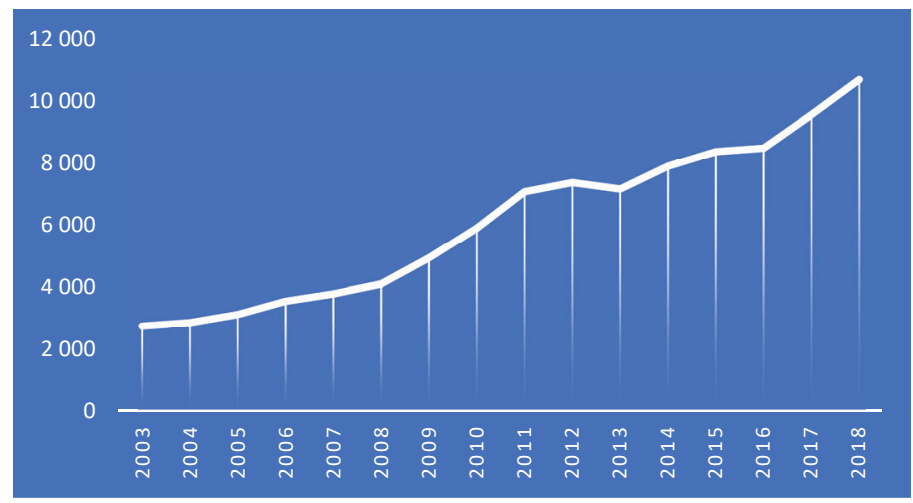

${ }^{1}$ Niektóre publikacje zostały przypisane do kilku kategorii jednocześnie, dlatego suma jest mniejsza od prostego dodania podanych wartości. Zapytanie do Web of Science: $\mathrm{WC}=($ management OR business OR business, finance OR psychology OR economics). Wyszukiwanie przeprowadzono 11.03.2020. 


\subsection{Bazy bibliograficzne}

Najważniejsze narzędzie niezbędne do przeprowadzania systematycznego przeglądu literatury to bazy bibliograficzne.

Bazy bibliograficzne zawierają informacje o publikacjach, tj. imię i nazwisko autora/ów, tytuł artykułu, tytuł periodyku naukowego, numer rocznika (volume), numer wydanie (issue), numery stron w roczniku/wydaniu, na których opublikowano artykuł oraz numer DOI (Digitial Object Identifier). Większość baz bibliograficznych zawiera również abstrakty (streszczenia) oraz słowa kluczowe i afiliacje (miejsce zatrudnienia) autorów. Bazy bibliometryczne zawierają informacje o cytowaniach poszczególnych publikacji, tj. informują, jak często inni autorzy powołują się na dane badanie. Bazy bibliograficzno-bibliometryczne łączą oba zbiory danych. Do sporządzenia systematycznego przeglądu literatury tematu wystarczą bazy bibliograficzne, jednak najpopularniejsze bazy wykorzystywane w tym celu zawierają również dane bibliometryczne, dlatego mówimy o bazach bibliograficzno-bibliometrycznych.

Najpopularniejsze bazy bibliograficzno-bibliometryczne stosowane do przygotowania przeglądów literatury tematu to Web of Science (Clarivate Analytics) oraz Scopus (Elsevier). Sposób korzystania z obu baz jest bardzo podobny, jednak różnią się one pod względem możliwości definiowania pól do przeszukiwania oraz zawartością, która jest w nich indeksowana.

Dla studentów i pracowników Uniwersytetu Warszawskiego dostęp do obu baz jest możliwy z adresu:

https://www.buw.uw.edu.pl/zasoby-online/bazy-online/

Z każdej z baz można korzystać z dowolnego komputera podłączonego do Internetu, jednak, jeśli ten komputer znajduje się poza budynkami (siecią) UW, konieczne jest podanie numeru karty bibliotecznej i hasła.

\subsubsection{Web of Science}

Przed rozpoczęciem pracy z Web of Science warto założyć darmowe konto (dla osób posiadających dostęp przez system uniwersytecki). Konto pozwala zapisywać wyniki wyszukiwania. Tworzymy je, klikając w prawym górnym rogu „Sign in”, a następnie wybierając „Register”.

Rysunek 2 przedstawia interfejs Web of Science z wyróżnieniem 4 stref: wybór trybu wyszukiwania (Advanced Search), strefy wyszukiwania, strefy podpowiedzi dotyczących pól do przeszukiwania oraz strefy z historią przeszukiwania i operacjami na rezultatach wyszukiwania. Po przeprowadzeniu wyszukiwania należy kliknąć w liczbę znalezionych rezultatów (oznaczone zielonym prostokątem w strefie „operacje na rezultatach wyszukiwania”), aby trafić do listy odnalezionych publikacji. 


\section{Rysunek 2. Interfejs bazy Web of Science (Advanced Search)}

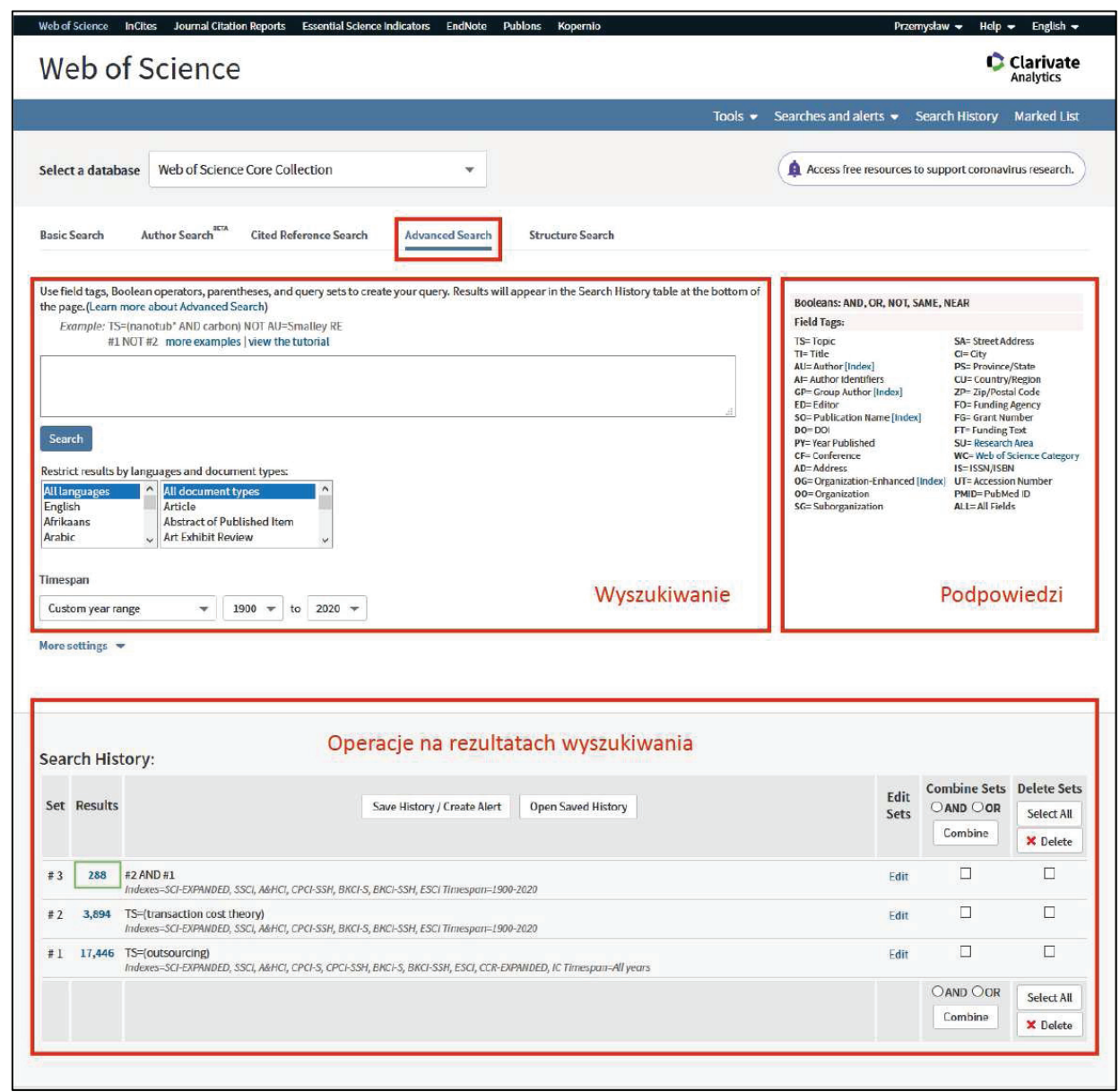

Pola wyszukiwawcze. Konstruowanie zapytania do bazy danych polega na określeniu słów kluczowych oraz sprecyzowaniu, które pola bazy mają być przeszukiwane w poszukiwaniu słów kluczowych (tabela 1). 
Tabela 1. Wybrane pola przeszukiwania bazy Web of Science (Advanced Search)

\begin{tabular}{|c|c|c|c|}
\hline Pole & Znaczenie & Przykład & Rezultat \\
\hline TS & $\begin{array}{l}\text { Topic (temat); przeszukiwane } \\
\text { są pola: tytuł, abstrakt, słowa } \\
\text { kluczowe przypisane przez } \\
\text { autorów i słowa kluczowe } \\
\text { przypisane przez Web of Science }\end{array}$ & $\mathrm{TS}=($ outsourcing $)$ & $\begin{array}{l}\text { znalezione zostaną wszystkie artykuły, które } \\
\text { zawierają słowo „outsourcing” w tytule } \\
\text { artykułu, abstrakcie i słowach kluczowych } \\
\text { publikacji }\end{array}$ \\
\hline TI & Title (tytuł) & $\mathrm{TI}=$ (outsourcing) & $\begin{array}{l}\text { znalezione zostaną wszystkie artykuły, które } \\
\text { zawierają słowo „outsourcing” } \\
\text { w tytule artykułu }\end{array}$ \\
\hline $\mathbf{A U}$ & Author (autor) & $\mathrm{AU}=($ James March $)$ & $\begin{array}{l}\text { znalezione zostaną artykuły naukowe } \\
\text { napisane przez Jamesa Marcha }\end{array}$ \\
\hline SO & $\begin{array}{l}\text { Source (źródło); przeszukiwane } \\
\text { jest pole zawierające tytuł } \\
\text { periodyku naukowego }\end{array}$ & $\begin{array}{l}\mathrm{SO}=(\text { Academy of Management } \\
\text { Journal) }\end{array}$ & $\begin{array}{l}\text { znalezione zostaną tekst opublikowane } \\
\text { w piśmie Academy of Management Journal }\end{array}$ \\
\hline DO & DOI (Digitial Object Identifier). & $\mathrm{DO}=(10.1177 / 1056492611432803)$ & $\begin{array}{l}\text { znaleziona zostanie publikacja: March, } \\
\text { J. G. (2011). A Scholar's Quest. Journal } \\
\text { of Management Inquiry, 20(4), 355-357 }\end{array}$ \\
\hline \multirow[t]{2}{*}{ PY } & \multirow[t]{2}{*}{ Publication Year (rok publikacji) } & $P Y=2015$ & $\begin{array}{l}\text { znalezione zostaną publikacje wydane } \\
\text { w roku } 2015\end{array}$ \\
\hline & & $P Y=(2010-2015)$ & $\begin{array}{l}\text { znalezione zostaną publikacje wydane } \\
\text { w latach } 2010-2015\end{array}$ \\
\hline SU & Research Area (dziedzina badań) & $\mathrm{SU}=$ Social Sciences & $\begin{array}{l}\text { znalezione zostaną artykuły zakwalifikowane } \\
\text { do nauk społecznych; uwaga, kategoryzacja } \\
\text { SU jest dość złożona, np. zarządzanie } \\
\text { znajduje się zarówno w dziedzinie „Social } \\
\text { Sciences”, jak i „Technology”, dlatego lepiej } \\
\text { nie używać tego pola wyszukiwawczego }\end{array}$ \\
\hline WC & $\begin{array}{l}\text { Web of Science Category } \\
\text { (kategoria Web of Science) }\end{array}$ & $\mathrm{WC}=$ management & $\begin{array}{l}\text { znalezione zostaną artykułu, które ukazały } \\
\text { się na łamach pism zaliczonych do kategorii } \\
\text { „management” ( } 217 \text { pism); pokrewne } \\
\text { kategorie to: „Business” } \\
\text { (147 pism), „Business, Finance” (103 pisma) }\end{array}$ \\
\hline IS & $\begin{array}{l}\text { Numer ISSN } \\
\text { (pisma naukowe)/ISBN (książki) }\end{array}$ & IS $=0001-4273$ & $\begin{array}{l}\text { znalezione zostaną artykuły opublikowane } \\
\text { w piśmie o tym numerze ISSN (Academy of } \\
\text { Management Journal); uwaga: obecnie wiele } \\
\text { pisma ma dwa numery ISSN: tradycyjny } \\
\text { i elektroniczny; obu można używać do } \\
\text { przeszukiwania pola „IS” }\end{array}$ \\
\hline DT & Document Type & $\mathrm{DT}=($ Article $)$ & odnalezione zostaną tylko artykuły naukowe ${ }^{8}$ \\
\hline LA & Language & $\mathrm{LA}=($ English $)$ & $\begin{array}{l}\text { znalezione zostaną artykuły opublikowane } \\
\text { w języku angielskim }\end{array}$ \\
\hline ALL & Przeszukiwane są wszystkie pola & & \\
\hline
\end{tabular}

8 Typy dokumentów w WoS to: Article; Abstract of Published Item; Art Exhibit Review; Bibliography; Biographical-Item; Book; Book Chapter; Book Review; Chronology; Correction; Correction, Addition; Dance Performance Review; Data Paper; Database Review; Discussion; Early Access (Web of Science Core Collection only); Editorial Material; Excerpt; Fiction, Creative Prose; Film Review; Hardware Review; Item About an Individual; Letter; Meeting Abstract; Meeting Summary; Music Performance Review; Music Score; Music Score Review; News Item; Note; Poetry; Proceedings Paper; Record Review; Reprint; Retracted Publication; Retraction; Review; Script; Software Review; TV Review, Radio Review; TV Review, Radio Review, Video; Theater Review. 
Kategorie, do których Web of Science przypisuje periodyki naukowe w pewnym stopniu się pokrywają, co pokazuje tabela 2. Jednak żadna z tych kategorii nie obejmuje wszystkich periodyków, w których publikowane są teksty związane z szeroko rozumianym zarządzaniem. Dlatego należy albo unikać ograniczania wyszukiwań przez polecenie WC, albo przeszukiwać wszystkie trzy kategorie jednocześnie: $\mathrm{WC}=($ Management OR Business OR Business, Finance $)$.

Tabela 2. Kategorie Web of Science związane z tematyką nauk o zarządzaniu i jakości

\begin{tabular}{|l|r|}
\multicolumn{1}{|c|}{ Kategoria WoS } & Liczba wyników \\
\hline Management OR Business OR Business, Finance & 1233794 \\
\hline Management & 750145 \\
\hline Business & 665516 \\
\hline Business, Finance & 257110 \\
\hline Management AND Business & 181867 \\
\hline Management AND Business, Finance & 20939 \\
\hline
\end{tabular}

\section{Konstruowanie zapytania do bazy danych (search string)}

Formułując wyszukiwania w bazie Web of Science, posługujemy się operatorami logicznymi (tabela 3) oraz znakami specjalnymi (tabela 4).

Tabela 3. Operatory logiczne i ich stosowanie w bazie Web of Science

\begin{tabular}{|c|c|c|c|}
\hline Operator & Znaczenie & Przykład & Rezultat \\
\hline AND & I & $\begin{array}{l}\mathrm{TS}=(\text { organization } \mathrm{AND} \\
\text { performance })\end{array}$ & $\begin{array}{l}\text { znalezione zostaną } 96102 \text { publikacje, które } \\
\text { zawierają jednocześnie słowa „organization” } \\
\text { i „performance” }\end{array}$ \\
\hline OR & LUB & $\begin{array}{l}\mathrm{TS}=(\text { organization } \mathrm{OR} \\
\text { performance })\end{array}$ & $\begin{array}{l}\text { znalezione zostaną } 4887211 \text { publikacje, } \\
\text { które zawierają słowa „organization” } \\
\text { lub ,performance” }\end{array}$ \\
\hline NOT & NIE & $\begin{array}{l}\mathrm{TS}=(\text { organization NOT } \\
\text { performance })\end{array}$ & $\begin{array}{l}\text { znalezione zostaną } 746564 \text { publikacje, które } \\
\text { zawierają pojęcia „organization”, ale nie } \\
\text { zawierają słowa „performance” }\end{array}$ \\
\hline $\mathrm{NEAR} / \mathrm{x}$ & $\begin{array}{l}\text { W POBLIŻU/x } \\
\text { słów }\end{array}$ & $\begin{array}{l}\mathrm{TS}=\text { (organization NEAR } / 3 \\
\text { performance) }\end{array}$ & $\begin{array}{l}\text { znalezione zostaną } 7122 \text { publikacje, w których } \\
\text { słowo performance znajduje się nie dalej niż } \\
\text { w odległości } 3 \text { słów od słowa „organization” }\end{array}$ \\
\hline SAME & TAKI SAM & $\begin{array}{l}\mathrm{AD}=(\text { University SAME } \\
\text { Warsaw) }\end{array}$ & $\begin{array}{l}\text { polecenie wykorzystywane tylko do } \\
\text { przeszukiwania pola Address (AD); } \\
\text { zastosowane do przeszukiwania innych pól daje } \\
\text { ten sam rezultat co AND; znalezione zostaną } \\
\text { 109,955 teksty, w których w polu Address } \\
\text { znajdują się jednocześnie słowa „University” } \\
\text { i „Warsaw” }\end{array}$ \\
\hline
\end{tabular}


Tabela 4. Znaki specjalne $w$ wyszukiwaniach w Web of Science

\begin{tabular}{|c|c|c|c|}
\hline $\begin{array}{c}\text { Znak } \\
\text { specjalny }\end{array}$ & Znaczenie & Przykład & Rezultat \\
\hline$*$ & $\begin{array}{l}\text { zastępuje ciąg znaków } \\
\text { o dowolnej długości; przydatny } \\
\text { do wyszukiwania różnych form } \\
\text { słowa (rzeczowniki, przymiotniki) }\end{array}$ & $\mathrm{TI}=($ metaana $*)$ & $\begin{array}{l}\text { znajduje publikacje, } \\
\text { które mają w tytule } \\
\text { słowa: } \\
\text { metaanalysis } \\
\text { metaanalyses } \\
\text { metaanalytic }\end{array}$ \\
\hline \multirow[t]{2}{*}{$?$} & \multirow{2}{*}{$\begin{array}{l}\text { zastępuje pojedynczy znak; } \\
\text { przydatny do wyszukiwania } \\
\text { z uwzględnieniem różnic } \\
\text { w pisowni amerykańskiej } \\
\text { i angielskiej wersji języka } \\
\text { angielskiego (,,z” vs ,s”) } \\
\text { oraz wyszukiwania liczby mnogiej } \\
\text { (,e” vs „,a”) }\end{array}$} & $\mathrm{TI}=($ organi$?$ ation $)$ & $\begin{array}{l}\text { znajduje publikacje, } \\
\text { które mają w tytule } \\
\text { słowa: } \\
\text { organization } \\
\text { organisation }\end{array}$ \\
\hline & & $\mathrm{TI}=(\mathrm{m} ? \mathrm{n})$ & $\begin{array}{l}\text { znajduje publikacje, } \\
\text { które mają w tytule } \\
\text { słowa: } \\
\text { man } \\
\text { men }\end{array}$ \\
\hline \multirow[t]{2}{*}{$\$$} & \multirow{2}{*}{$\begin{array}{l}\text { zastępuje pojedynczy znak } \\
\text { lub brak znaku; przydatny } \\
\text { do wyszukiwania } \\
\text { z uwzględnieniem różnic } \\
\text { w pisowni amerykańskiej } \\
\text { i angielskiej wersji języka } \\
\text { angielskiego, również } \\
\text { do wyszukiwania liczby mnogiej }\end{array}$} & $\mathrm{TI}=($ behavio $\$ \mathrm{r})$ & $\begin{array}{l}\text { znajduje publikacje, } \\
\text { które mają w tytule } \\
\text { słowa: } \\
\text { behaviour } \\
\text { behavior }\end{array}$ \\
\hline & & $\mathrm{TI}=($ organization $\$)$ & $\begin{array}{l}\text { znajduje publikacje, } \\
\text { które mają w tytule } \\
\text { słowa: } \\
\text { organization } \\
\text { organizations }\end{array}$ \\
\hline
\end{tabular}

UWAGA: wiele edytorów tekstu, w tym MS Word, podczas wpisywania zamienia górne cudzysłowy na dolne, czyli ciąg znaków "evidence based" zostaje zamieniony na „evidence based”. Dolny cudzysłów jest niezrozumiały dla Web of Science, sygnalizuje więc błąd ciągu wyszukiwawczego. Niestety, jeśli w ciągu wyszukiwania znajdują się również frazy, które zwrócą jakiś wynik (np. TS=(reliable OR „evidence based”)), to WoS nie poinformuje nas o błędzie. W rezultacie uzyskamy liczbę wyników, ale będzie ona błędna - co gorsza, nie będziemy o tym wiedzieli. Dlatego należy zwracać szczególną uwagę na cudzysłowy w wyszukiwaniach, a sam ciąg wyszukiwania najlepiej przygotowywać w innym edytorze tekstów (np. darmowym Notepad++). 


\section{Operacje na rezultatach wyszukiwania}

Web of Science pozwala wykonywać podstawowe operacje logiczne na rezultatach przeszukiwania. Każdy rezultat jest zapisywany jako zbiór (set) i oznaczany numerem kolejnym. Te operacje są przydatne, gdy przejrzeliśmy już rezultaty jednego wyszukiwania (\#1), a następnie prowadzimy szerzej zakrojone wyszukiwanie (\#2). Dzięki operacji na zbiorach możemy z szerszego wyszukiwania wyłączyć wyniki, które już przejrzeliśmy (\#2 NOT \#1).

Tabela 5. Operacja na wynikach wyszukiwań

\begin{tabular}{|c|c|}
\hline Polecenie & Rezultat \\
\hline \#1 OR \#2 & suma zbiorów 1 i 2 \\
\hline \#1 AND \#2 & część wspólna zbiorów 1 i 2 \\
\hline \#1 NOT \#2 & wyniki ze zbioru 1 , pomniejszone o wyniki znajdujące się w zbiorze 2 \\
\hline
\end{tabular}

\subsubsection{Scopus}

Z pełnych możliwości bazy Scopus (np. łatwego eksportu wyniku wyszukiwania do Mendeley) można korzystać tylko po zalogowaniu do konta użytkownika w bazie Scopus. Dlatego pracę z bazą warto rozpocząć do utworzenia takiego konta. Podczas pierwszej wizyty na stronie Scopus pojawi się okienko witające w bazie („Welcome to Scopus”) - w celu utworzenia konta klikamy opcję „Create account".

Rysunek 3 przedstawia interfejs bazy Scopus z wyróżnieniem 3 stref: wybór trybu wyszukiwania (Advanced), strefy wyszukiwania oraz strefy podpowiedzi dotyczących pól do przeszukiwania. Podstawowa różnica między Scopus a Web of Science polega na tym, że nazw pól wyszukiwawczych (ABS, TITLE itd.) nie trzeba wpisywać z klawiatury - wystarczy nacisnąć znak „+” przy wybranym polu wyszukiwania (znaki „,+ są widoczne po rozwinięciu opisu poszczególnych kategorii pól wyszukiwawczych). Uwaga: Scopus wstawi nazwę pola do przeszukiwania w miejscu, w którym znajduje się kursor, więc bardzo łatwo można wygenerować błędny string wyszukiwania, np. „TITLE-A TITLE-ABS-KEY()BS()” (pole TITLE-ABS-KEY zostało pomyłkowo wstawione w pole TITLE-ABS). 
Rysunek 3. Interfejs bazy Scopus (Advanced Search)

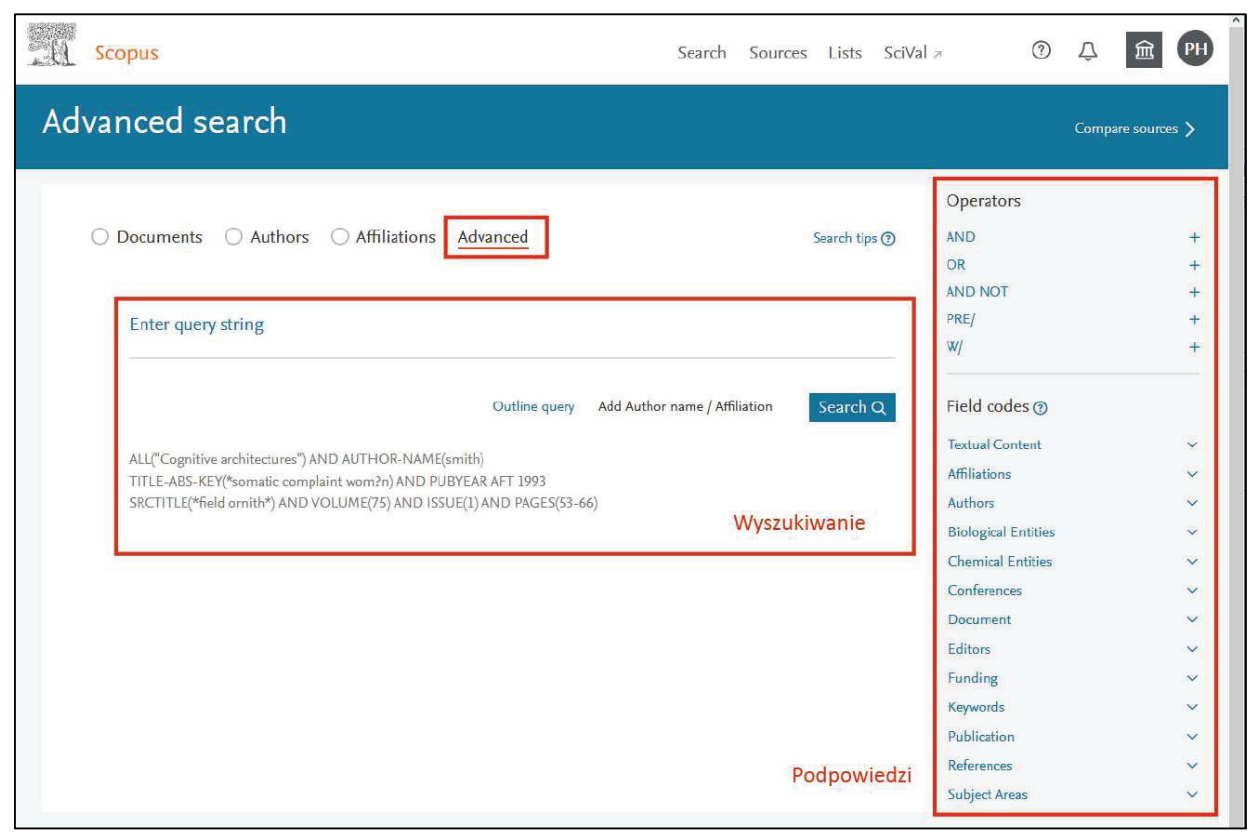

Pola wyszukiwawcze. Konstruowanie zapytania do bazy danych polega na określeniu słów kluczowych oraz sprecyzowaniu, które pola bazy danych system ma przeszukiwać w poszukiwaniu słów kluczowych (tabela 6). 
Tabela 6. Wybrane pola przeszukiwania bazy Scopus (Advanced Search)

\begin{tabular}{|c|c|c|c|}
\hline Pole & Znaczenie & Przykład & Rezultat \\
\hline ABS & Abstrakt (streszczenie) & ABS(outsourcing) & $\begin{array}{l}\text { znalezione zostaną wszystkie artykuły, które } \\
\text { zawierają słowo outsourcing w abstrakcie }\end{array}$ \\
\hline TITLE & Tytu1 & TITLE(outsourcing) & $\begin{array}{l}\text { znalezione zostaną wszystkie artykuły, które } \\
\text { zawierają słowo outsourcing w tytule }\end{array}$ \\
\hline KEY & $\begin{array}{l}\text { Słowa kluczowe (wyszukiwanie } \\
\text { zbiorcze) }\end{array}$ & KEY(outsourcing) & $\begin{array}{l}\text { połączone wyszukiwanie wszystkich typów pól } \\
\text { zawierających słowa kluczowe (AUTHKEY, } \\
\text { INDEXTERMS, TRADENAME, CHEMNAME). }\end{array}$ \\
\hline AUTHKEY & $\begin{array}{l}\text { Słowa kluczowe przypisane } \\
\text { przez autora artykułu }\end{array}$ & AUTHKEY(outsourcing) & $\begin{array}{l}\text { znalezione zostaną publikacje o outsourcingu, } \\
\text { tylko wtedy, gdy autor użył tego pojęcia jako słowa } \\
\text { kluczowego }\end{array}$ \\
\hline INDEXTERMS & $\begin{array}{l}\text { Słowa kluczowe przypisane } \\
\text { przez Scopus }\end{array}$ & INDEXTERMS(outsourcing) & $\begin{array}{l}\text { znalezione zostaną publikacje o outsourcingu, tylko } \\
\text { wtedy, gdy Scopus użył tego pojęcia jako słowa } \\
\text { kluczowego }\end{array}$ \\
\hline TITLE-ABS & Tytuł i abstrakt & TITLE-ABS(outsourcing) & $\begin{array}{l}\text { znalezione zostaną wszystkie artykuły, które } \\
\text { zawierają słowo outsourcing w tytule lub abstrakcie }\end{array}$ \\
\hline $\begin{array}{l}\text { TITLE-ABS- } \\
\text { KEY }\end{array}$ & $\begin{array}{l}\text { Tytul, abstrakt, słowa } \\
\text { kluczowe }\end{array}$ & TITLE-ABS-KEY(outsourcing) & $\begin{array}{l}\text { znalezione zostaną wszystkie artykuły, które } \\
\text { zawierają słowo outsourcing w tytule, abstrakcie lub } \\
\text { słowach kluczowych }\end{array}$ \\
\hline SRCTITLE & $\begin{array}{l}\text { Źródło; przeszukiwane } \\
\text { jest pole zawierające tytuł } \\
\text { periodyku naukowego }\end{array}$ & $\begin{array}{l}\text { SRCTITLE(Academy } \\
\text { of Management Journal) }\end{array}$ & $\begin{array}{l}\text { znalezione zostaną tekst opublikowane w piśmie } \\
\text { Academy of Management Journal }\end{array}$ \\
\hline ISSN & $\begin{array}{l}\text { Numer ISSN periodyku } \\
\text { naukowego }\end{array}$ & ISSN(0001-4273) & $\begin{array}{l}\text { znalezione zostaną artykuły opublikowane w piśmie } \\
\text { o tym numerze ISSN (Academy of Management } \\
\text { Journal); uwaga: obecnie wiele pisma ma dwa } \\
\text { numery ISSN: tradycyjny i elektroniczny }\end{array}$ \\
\hline AUTH & Autor & AUTH(James March) & $\begin{array}{l}\text { znalezione zostaną artykuły naukowe napisane przez } \\
\text { Jamesa Marcha }\end{array}$ \\
\hline DOI & $\begin{array}{l}\text { DOI (Digitial Object } \\
\text { Identifier). }\end{array}$ & DOI(10.1177/1056492611432803) & $\begin{array}{l}\text { znaleziona zostanie publikacja: March, J.G. (2011). } \\
\text { A Scholar's Quest. Journal of Management Inquiry, } \\
\text { 20(4), 355-357 }\end{array}$ \\
\hline SUBJAREA & Obszar tematyczny & SUBJAREA(BUSI) & $\begin{array}{l}\text { znalezione zostaną wszystkie publikacje przypisane } \\
\text { do kategorii „Business, Management, and } \\
\text { Accounting” }\end{array}$ \\
\hline ALL & $\begin{array}{l}\text { Przeszukiwane są pola: } \\
\text { ABS, AFFIL, ARTNUM, } \\
\text { AUTH, AUTHCOLLAB, } \\
\text { CHEM, CODEN, CONF, } \\
\text { DOI, EDITOR, ISBN, ISSN, } \\
\text { ISSUE, KEY, LANGUAGE, } \\
\text { MANUFACTURER, } \\
\text { PUBLISHER, PUBYEAR, } \\
\text { REF, SEQBANK, } \\
\text { SEQNUMBER, SRCTITLE, } \\
\text { VOLUME i TITLE }\end{array}$ & ALL(outsourcing) & $\begin{array}{l}\text { znalezionych zostanie } 80233 \text { dokumentów, które } \\
\text { zawierają słowo „outsourcing” w którymś z pól } \\
\text { wymienionych w drugiej kolumnie }\end{array}$ \\
\hline
\end{tabular}




\section{Konstruowanie ciągu wyszukiwawczego (search string)}

Formułując wyszukiwania w bazie Scopus, posługujemy się operatorami logicznymi (tabela 7) oraz znakami specjalnymi (tabela 8).

Baza Scopus poddaje słowa wyszukiwawcze automatycznej lemmatyzacji. Oznacza to, że poszukiwane są wszystkie formy wpisanych słów (np. organization, organizations, organizational), nie jest zatem konieczne posługiwanie się znakami specjalnymi (*, ?, \$). Automatycznie uwzględniane są również różnice w amerykańskiej i brytyjskiej pisowni (behavior vs behaviour) oraz znaki diakrytyczne (źółty vs zolty). Te funkcje możemy wyłączyć i poszukiwać tylko podstawowej formy słowa, posługując się komendą EXACT PHRASE.

Tabela 7. Operatory logiczne w bazie Scopus

\begin{tabular}{|c|c|c|c|}
\hline Operator & Znaczenie & Przykład & Rezultat \\
\hline AND & I & $\begin{array}{l}\text { TITLE (organization AND } \\
\text { performance) }\end{array}$ & $\begin{array}{l}\text { znalezione zostaną } \\
2734 \text { teksty, które w tytule } \\
\text { zawierają jednocześnie słowa } \\
\text { „organization” } \\
\text { i „performance” }\end{array}$ \\
\hline OR & LUB & $\begin{array}{l}\text { TITLE (organization OR } \\
\text { performance) }\end{array}$ & $\begin{array}{l}\text { znalezione zostaną } \\
1148665 \text { teksty, które } \\
\text { w tytule zawierają słowa } \\
\text { „organization” } \\
\text { lub „performance” }\end{array}$ \\
\hline $\begin{array}{l}\text { AND } \\
\text { NOT }\end{array}$ & NIE & $\begin{array}{l}\text { TITLE (organization AND } \\
\text { NOT performance) }\end{array}$ & $\begin{array}{l}\text { znalezione zostaną } \\
166459 \text { teksty, które } \\
\text { w tytule zawierają } \\
\text { pojęcia „organization”, } \\
\text { ale nie zawierają słowa } \\
\text { „performance” }\end{array}$ \\
\hline PRE $/ x$ & PRZED/x słów & $\begin{array}{l}\text { TITLE (organization PRE/3 } \\
\text { performance) }\end{array}$ & $\begin{array}{l}\text { znalezione zostaną } 677 \\
\text { teksty, w których tytułach } \\
\text { słowo „performance” } \\
\text { znajduje się nie dalej niż } \\
\text { w odległości } 3 \text { słów od słowa } \\
\text { „organization” }\end{array}$ \\
\hline $\mathbf{W} / \mathbf{x}$ & $\begin{array}{l}\text { W ZAKRESIE/x } \\
\text { słów }\end{array}$ & $\begin{array}{l}\text { TITLE (organization W/3 } \\
\text { performance) }\end{array}$ & $\begin{array}{l}\text { znalezione zostaną } \\
1444 \text { teksty, w których tytule } \\
\text { słowa „organization” } \\
\text { and „performance” znajdują } \\
\text { się nie dalej od siebie } \\
\text { niż } 3 \text { słowa }\end{array}$ \\
\hline
\end{tabular}


Tabela 8. Znaki specjalne w wyszukiwaniach w Scopus

\begin{tabular}{|c|c|c|c|}
\hline $\begin{array}{c}\text { Znak } \\
\text { specjalny }\end{array}$ & Znaczenie & Przykład & Rezultat \\
\hline$*$ & $\begin{array}{l}\text { zastępuje ciąg znaków o dowolnej } \\
\text { długości; uwaga, również ciąg } \\
\text { o długości } 0 \text { znaków. Jest to więc } \\
\text { połączenie znaków * i \$ z Web } \\
\text { of Science }\end{array}$ & TITLE(metaana*) & $\begin{array}{l}\text { znajduje } \\
\text { publikacje, które } \\
\text { mają w tytule } \\
\text { słowa: } \\
\text { metaanalysis } \\
\text { metaanalyses } \\
\text { metaanalytic }\end{array}$ \\
\hline$?$ & $\begin{array}{l}\text { zastępuje pojedynczy znak; przydatny } \\
\text { do wyszukiwania liczby mnogiej } \\
(\text { (e” vs „,a”) }\end{array}$ & TITLE $=(m ? n)$ & $\begin{array}{l}\text { znajduje } \\
\text { publikacje, które } \\
\text { mają w tytule } \\
\text { słowa: } \\
\text { man } \\
\text { men }\end{array}$ \\
\hline
\end{tabular}

\subsubsection{Porównanie zasięgu Web of Science i Scopus}

Rysunek 4 pokazuje różnice w pokryciu baz Web of Science i Scopus dla sześciu najbardziej prestiżowych pism naukowych z dziedziny zarządzanie (Academy of Management Journal, Academy of Management Review, Organization Science, Strategic Management Journal, Administrative Science Quarterly i Organization Studies). Web of Science indeksuje 17485 dokumentów, podczas gdy Scopus jedynie 10 045. Po 2009 roku różnica się zmniejsza, jednak nawet w 2019 roku WoS indeksuje o 23 więcej dokumentów niż Scopus.

Tabela 9 pokazuje wyniki wyszukiwania opartego na słowach kluczowych, a nie na przeszukiwaniu wybranych periodyków naukowych. W tym przypadku większą liczbę źródeł znajdziemy w bazie Scopus, z uwagi na fakt, że indeksowana jest w nim znacznie większa liczba czasopism. Różnice w specyfice pokrycia publikacji powodują, że systematyczny przegląd literatury powinien być sporządzony za pomocą co najmniej dwóch baz bibliograficznych. 
Rysunek 4. Liczba tekstów opublikowanych w 6 najbardziej prestiżowych pismach w naukach o zarządzaniu indeksowana przez bazy Web of Science i Scopus. Zapytanie dla Web of Science: IS=(0001-4273 OR 1047-7039 OR 0143-2095 OR 0001-8392 OR 0170-8406 OR 0363-7425). Zapytanie dla Scopus: ISSN (0001-4273 OR 1047-7039 OR 0143-2095 OR 0001-8392 OR 0170-8406 OR 0363-7425). Wyszukiwanie przeprowadzono 6.03.2020

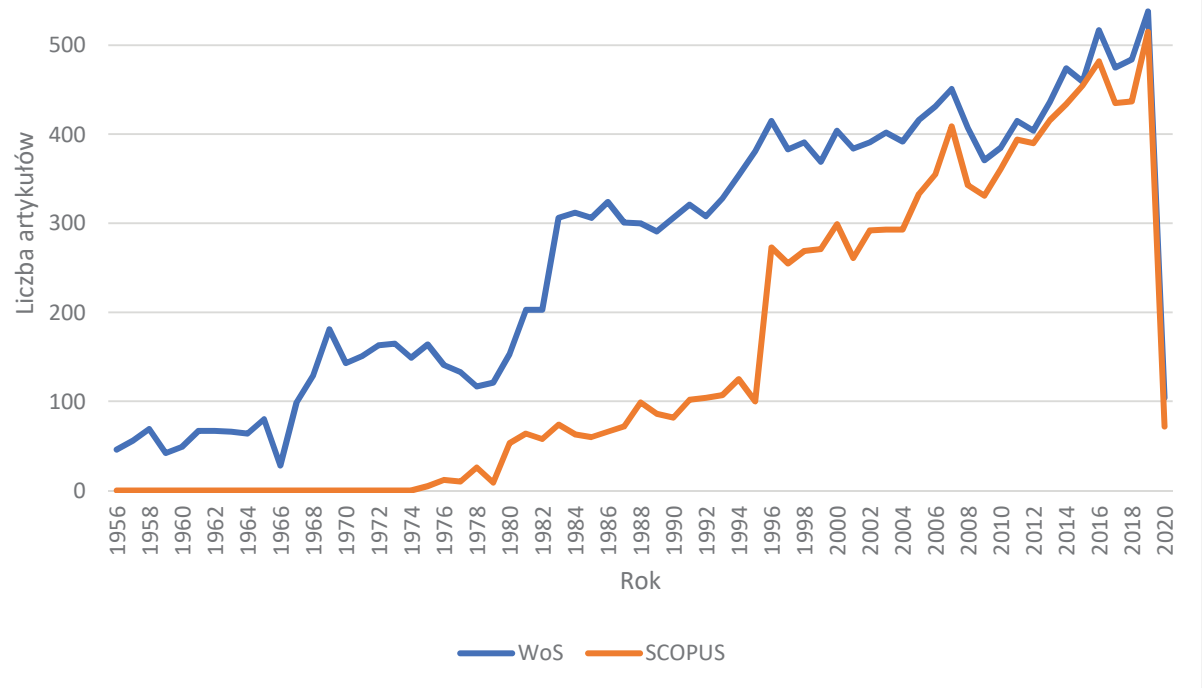


Tabela 9. Liczba dokumentów znalezionych w Web of Science i Scopus. Zapytanie do Web of Science: TI=(organization AND performance). Zapytanie do Scopus: TITLE (organization AND performance)

\begin{tabular}{|l|r|r|}
\hline \multicolumn{1}{|c|}{ Typ dokumentu } & Scopus & Wos \\
\hline Article & 2008 & 1348 \\
\hline Conference Paper & 429 & 505 \\
\hline Review & 122 & 198 \\
\hline Book Chapter & 83 & 78 \\
\hline Book & 19 & 15 \\
\hline Note & 18 & 11 \\
\hline Erratum & 14 & 4 \\
\hline Editorial & 12 & 54 \\
\hline Letter & 10 & 9 \\
\hline Short Survey & 2 & 2 \\
\hline Retracted & 1 & 1 \\
\hline Data Paper & 10 & \\
\hline Undefined & & 104 \\
\hline Meeting abstract & & 11 \\
\hline Early Access & & 4 \\
\hline News Item & & 1 \\
\hline Biographical Note & & 2346 \\
\hline Discussion & & \\
\hline Razem & & \\
\hline
\end{tabular}

\subsection{Inne bazy bibliograficzne}

Systematyczny przegląd literatury (SPL) powinien być sporządzony na podstawie co najmniej dwóch baz danych. Jednak zarówno ich liczba, jak i dobór zależą przede wszystkim od tematu SPL. W niniejszym poradniku zachęcam do skorzystania z Web of Science oraz Scopus, ale warto szukać publikacji również w innych bazach. W szczególności należy rozważyć użycie:

- Business Source Ultimate (EBSCO),

- bazy ProQuest, w szczególności ProQuest Dissertations \& Theses A\&I, zawierająca doktoraty,

- bazy najważniejszych wydawców pism naukowych: SAGE Journals, Taylor \& Francis, Emerald Insight. 
Jeśli chcemy uwzględnić badania w języku polskim i/lub dotyczące Polski, to warto posłużyć się następującymi źródłami:

- Polska Bibliografia Naukowa pbn.nauka.gov.pl/sedno-webapp/

- Central and Eastern European Online Library www.ceeol.com

- Directory of Open Access Repositories (Open DOAR) v2.sherpa.ac.uk/opendoar/ - nie jest to baza bibliograficzna lecz spis baz open access. Zawiera odnośniki do 113 baz z Polski i 394 baz z Europy Środkowej i Wschodniej.

Jeśli zdecydujemy się na uwzględnienie „szarej” literatury (patrz sekcja 2.2.1), to możemy włączyć do przeglądu również dowolne bazy/źródła, które indeksują tego rodzaju literaturę. Jednak poza bazą http://www.opengrey.eu/ trudno jest tu podać konkretne wskazówki, ponieważ wybór bazy będzie w decydującym stopniu zależał od tematu badania.

W poszukiwaniach „szarej” literatury może przydać się również Google Scholar. Zaawansowane opcje wyszukiwania znajdziemy pod adresem scholar.google. $\mathrm{com} / \# \mathrm{~d}=\mathrm{gs} \_$asd.

\subsection{Menedżer literatury}

Ilość literatury, która musi być przeanalizowana w SPL powoduje, że konieczne jest korzystanie z menedżerów danych bibliograficznych i plików PDF zawierających publikacje. Najpopularniejsze tego rodzaju narzędzia to EndNote, Mendeley i Zotero. EndNote stanowi standard wykorzystywany przez naukowców na całym świecie, jednak jest to aplikacja płatna. Dlatego warto rozważyć skorzystanie $\mathrm{z}$ bezpłatnych alternatyw, takich jak Mendeley ${ }^{2}$ i Zotero.

Menedżer literatury pozwala łatwo realizować następujące funkcje i cele:

- importować wyniki wyszukiwań przeprowadzonych w bazach bibliometrycznych,

- przyporządkowywać pliki PDF zawierające pełny tekst publikacji do poszczególnych pozycji literatury,

- cytować źródła w finalnej publikacji,

- automatycznie sporządzać bibliografię,

- dopasowywać format bibliografii do wymagań pisma naukowego/wydawcy/ wykładowcy.

Menedżer literatury pozwala również na łatwe przyporządkowywanie publikacji do kategorii i grup (teksty znalezione, teksty zakwalifikowane na podstawia analizy tytuły i abstraktu, teksty zakwalifikowane na podstawie lektury całej publikacji itd.).

\footnotetext{
${ }^{2}$ Do pobrania na mendeley.com.
} 


\subsubsection{Pobieranie wyników wyszukiwania z Web of Science do Mendeley}

Aby pobrać wyniki wyszukiwania w WoS do Mendeley, na stronie z rezultatami wyszukiwania w Web of Science (rysunek 5) naciskamy przycisk „More”, następnie wybieramy „Other File Formats”, w następnym oknie wybieramy „Records from $\mathrm{X}$ to $\mathrm{Y}$ ”, pod $\mathrm{X}$ podstawiając 1, a pod $\mathrm{Y}$ podstawiając liczbę wyszukanych artykułów. W polu „Record content” wybieramy „Full record”, natomiast w polu „File Format” wybieramy „BibTeX”. Następnie naciskamy „Export.” Na etapie eksportu możemy wskazać Mendeley jako aplikację, która ma otworzyć plik, co kończy procedurę importu. Innym rozwiązaniem jest zapisanie pliku na dysku i późniejsze zaimportowanie do Mendeley. W tym celu należy w aplikacji Mendeley ${ }^{3}$ wybrać menu „File”, następnie „Import...”, wybrać opcję BibTeX(.bib) i wskazać programowi wcześniej zapisany plik.

\section{Rysunek 5. Eksport danych bibliograficznych z Web of Science do Mendeley}

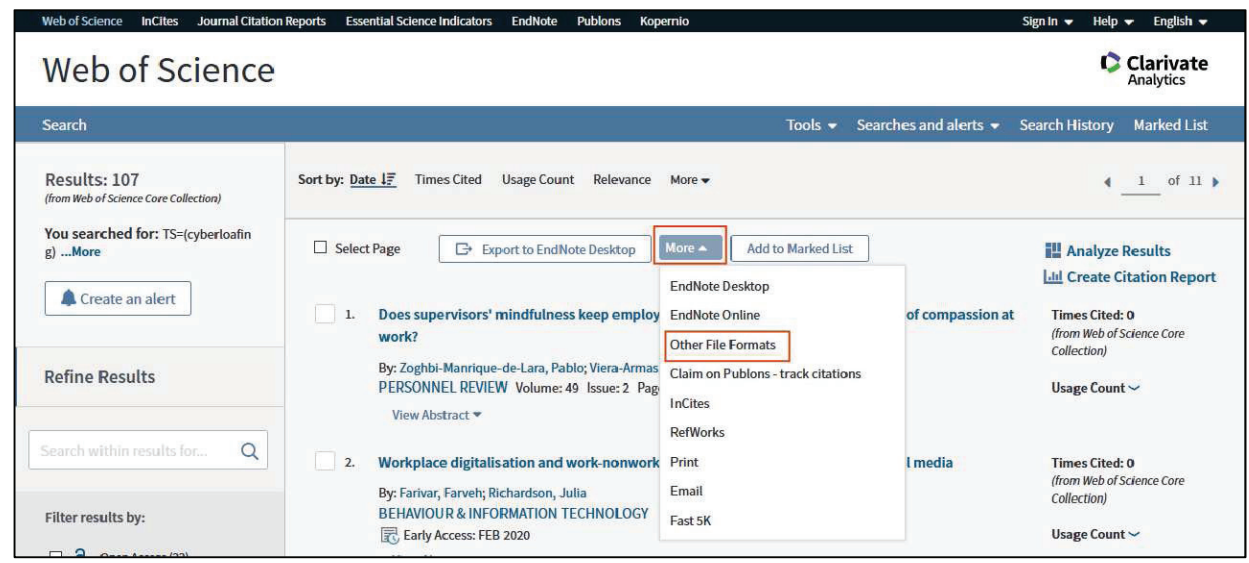

\subsubsection{Pobieranie wyników wyszukiwania ze Scopus do Mendeley}

Aby pobrać wyniki wyszukiwania w Scopus do Mendeley, na stronie z wynikami (rysunek 6) zaznaczamy okienko „All”. Uaktywnia się opcja „Save to Mendeley” (rysunek 6). Uwaga, opcja „Save to Mendeley” pokaże się tylko, jeśli jesteśmy zalogowani do naszego konta w bazie Scopus.

3 Mendeley Desktop v. 1.19.4. 
Rysunek 6. Eksport danych bibliograficznych ze Scopus do Mendeley, cz. 1

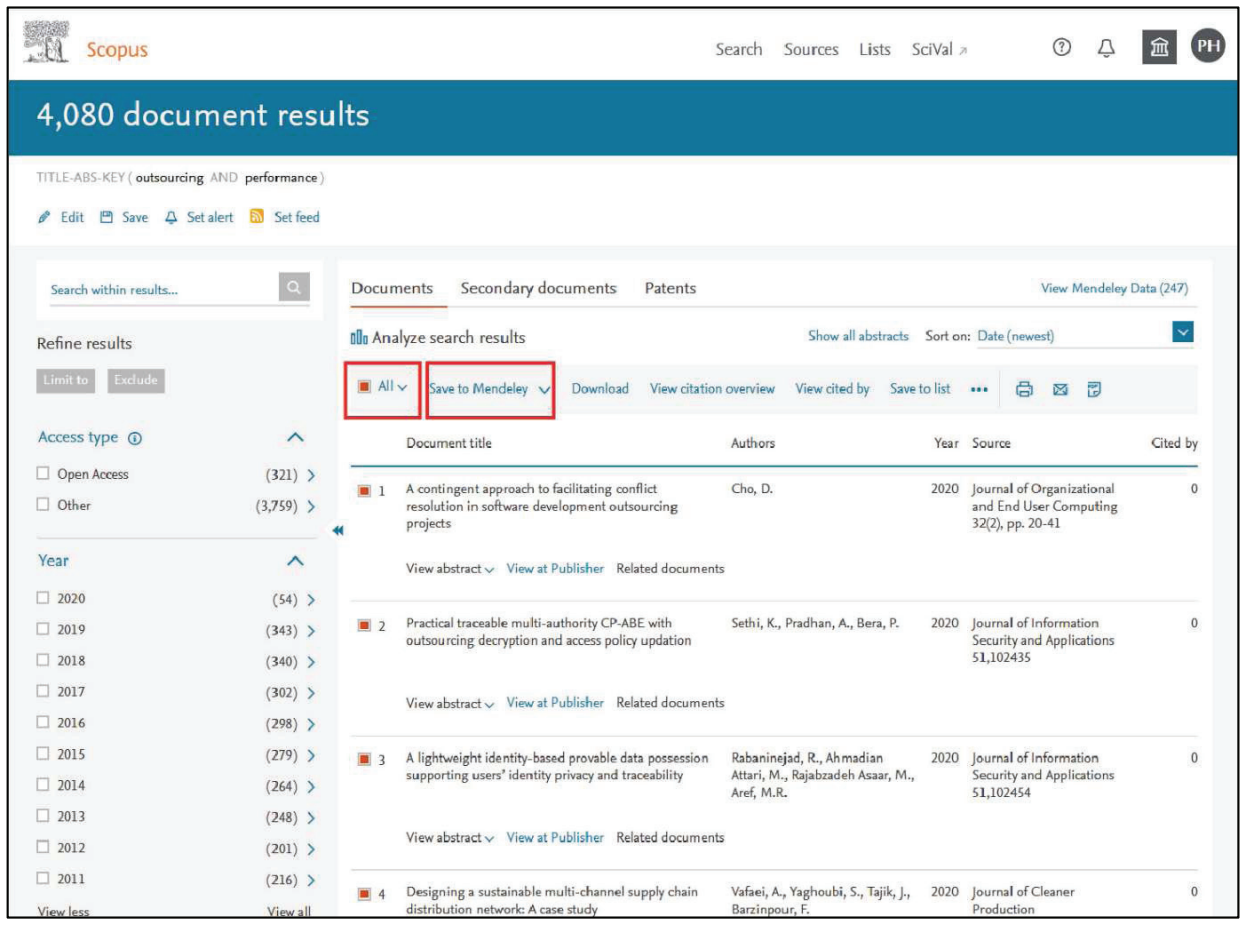

Po wybraniu tej opcji pojawi się kolejne okno, gdzie można wybrać bezpośredni eksport do Mendeley (rysunek 7).

\section{Rysunek 7. Eksport danych bibliograficznych ze Scopus do Mendeley, cz. 2}

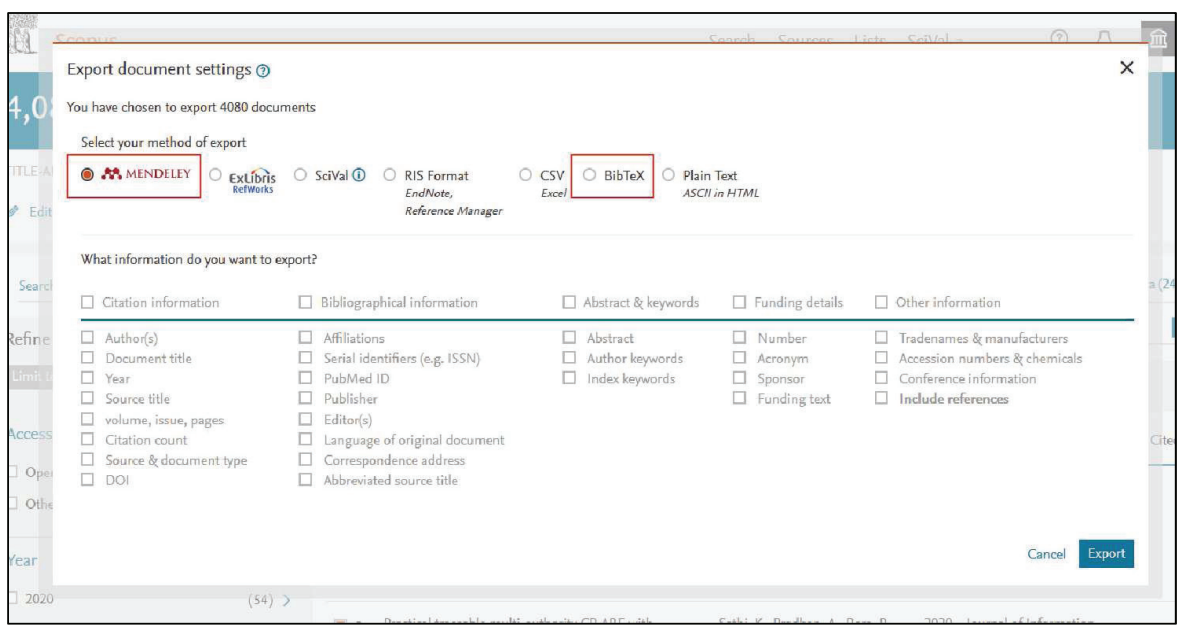


Po wybraniu Mendeley klikamy „Export”. Uwaga, na pozór nic się nie stanie, nie pojawi się żadne okno z pytaniem o to, gdzie zapisać plik. Dzieje się tak dlatego, że baza Scopus jest zintegrowana z menedżerem literatury Mendeley, który działa w chmurze. Zatem po naciśnięciu „Export” system Scopus zapisze wybrane przez nas dane bibliograficzne na naszym koncie Mendeley. Przy kolejnym otwarciu aplikacji Mendeley (lub przy zalogowaniu się do Mendeley przez stronę www) pobrane dane bibliograficzne będą już widoczne w bazie.

Drugi scenariusz importu danych ze Scopus polega na tym, że wyniki wyszukiwania eksportujemy w formacie BibTex i zapisujemy je na dysku. Następnie w aplikacji Mendeley wybieramy menu „File”, następnie „Import...”, wybieramy opcję „BibTeX(.bib)” i wskazujemy programowi wcześniej zapisany plik.

\subsubsection{Dodawanie plików PDF do danych bibliograficznych}

Aplikacja Mendeley sprawdza się nie tylko jako baza danych o artykułach, lecz także jako narzędzie do przechowywania (i łatwego odnajdywania) plików PDF zawierających pełne teksty artykułów. Przed przystąpieniem do „podczepiania” pełnych wersji artykułów warto ustawić preferencje programu Mendeley w ten sposób, by podczas importu program zmieniał nazwy plików PDF, tak by odpowiadały danym bibliograficznym (tzn. zamiast nazwy pliku „1-s2.0-S002463010900051X-main.pdf” będziemy mieli nazwę pliku „Teece - 2010 - Business Models, Business Strategy and Innovation.pdf"). W tym celu wybieramy z górnego paska menu opcję „Tools”, następnie „Options” i zaznaczamy kwadraty, jak na rysunku 8.

\section{Rysunek 8. Opcje programu Mendeley}

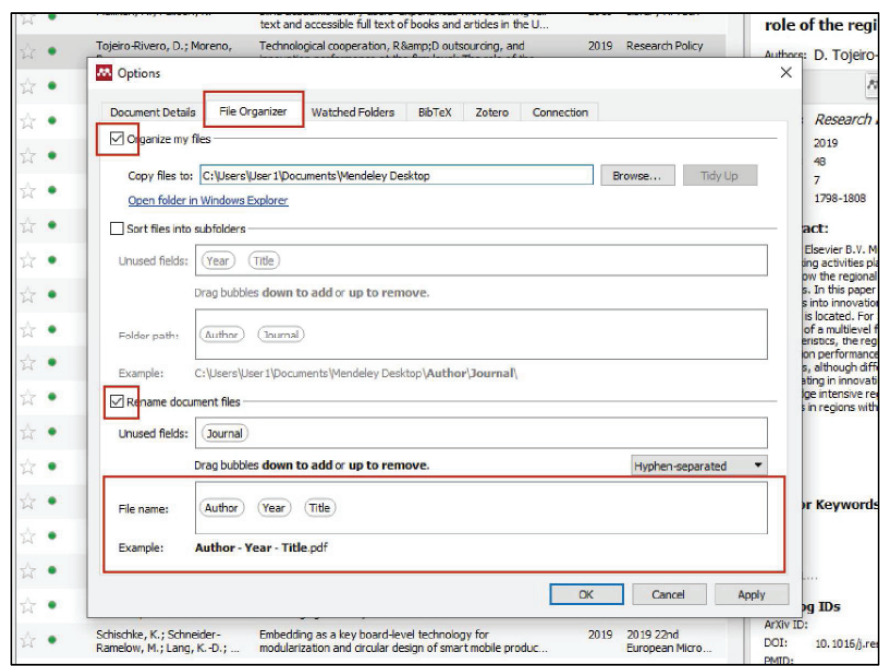


Aby „podczepić” plik PDF do konkretnego artykułu, należy wybrać artykuł na liście a następnie w prawym dolnym rogu kliknąć wyszarzony napis „Add File..." i wskazać miejsce na dysku, gdzie został zapisany plik PDF (rysunek 9). Plik zostanie połączony z danymi, a sam plik skopiowany do katalogu Mendeley pod zmienioną nazwą.

\section{Rysunek 9. Importowanie plików PDF do bazy w aplikacji Mendeley}

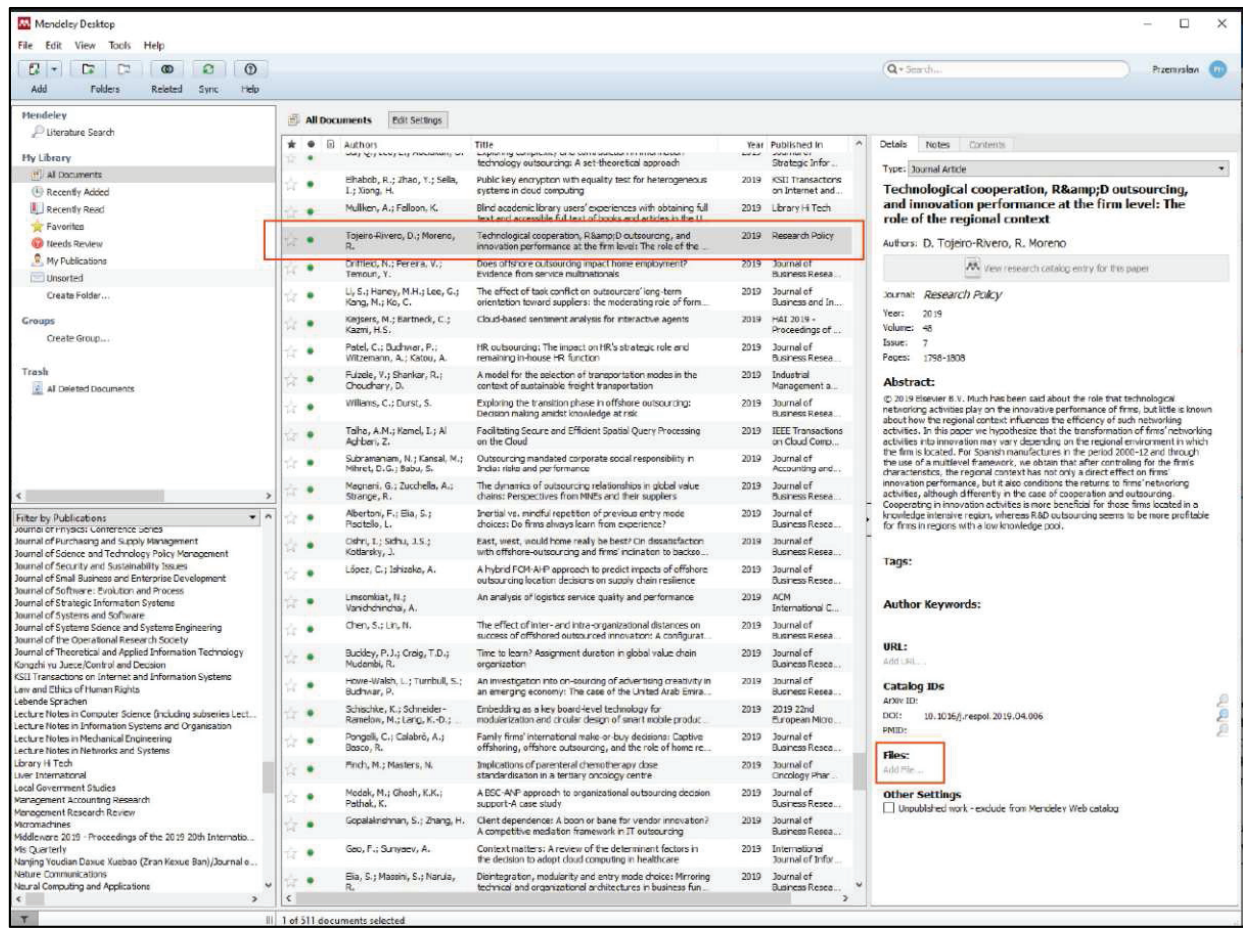

\subsubsection{Dodawania odwołań bibliograficznych (referencji) do dokumentu w MS Word}

Mendeley pozwala przechowywać i zarządzać literaturą tematu, ale również umożliwia łatwe dodawanie odnośników literaturowych do raportu z przeglądu literatury (rysunek 10). Po zainstalowaniu wtyczki Mendeley do MS Word ${ }^{4}$ w zakładce „References” pojawi się nowa sekcja z poleceniami dla programu Mendeley. W celu dodania odnośnika bibliograficznego (referencji, cytowania)

4 Wtyczkę do MS Word instalujemy z poziomu programu Mendeley Desktop. W aplikacji Mendeley Desktop wybieramy z górnego paska menu opcję „Tools”, następnie klikamy „Install MS Word Plugin" i postępujemy zgodnie z zalecaniami programu. 
należy: wybrać miejsce, w którym ma być wstawiony odnośnik bibliograficzny (1), kliknąć „Insert Citation” (2), pojawi się okienko wyszukiwania publikacji, w którym należy zacząć wpisywać nazwisko autora lub tytuł (3). Następnie należy wybrać właściwą pozycję literatury (4) i wcisnąć „OK” (5).

\section{Rysunek 10. Dodawanie odnośników bibliograficznych za pomocą programu Mendeley}

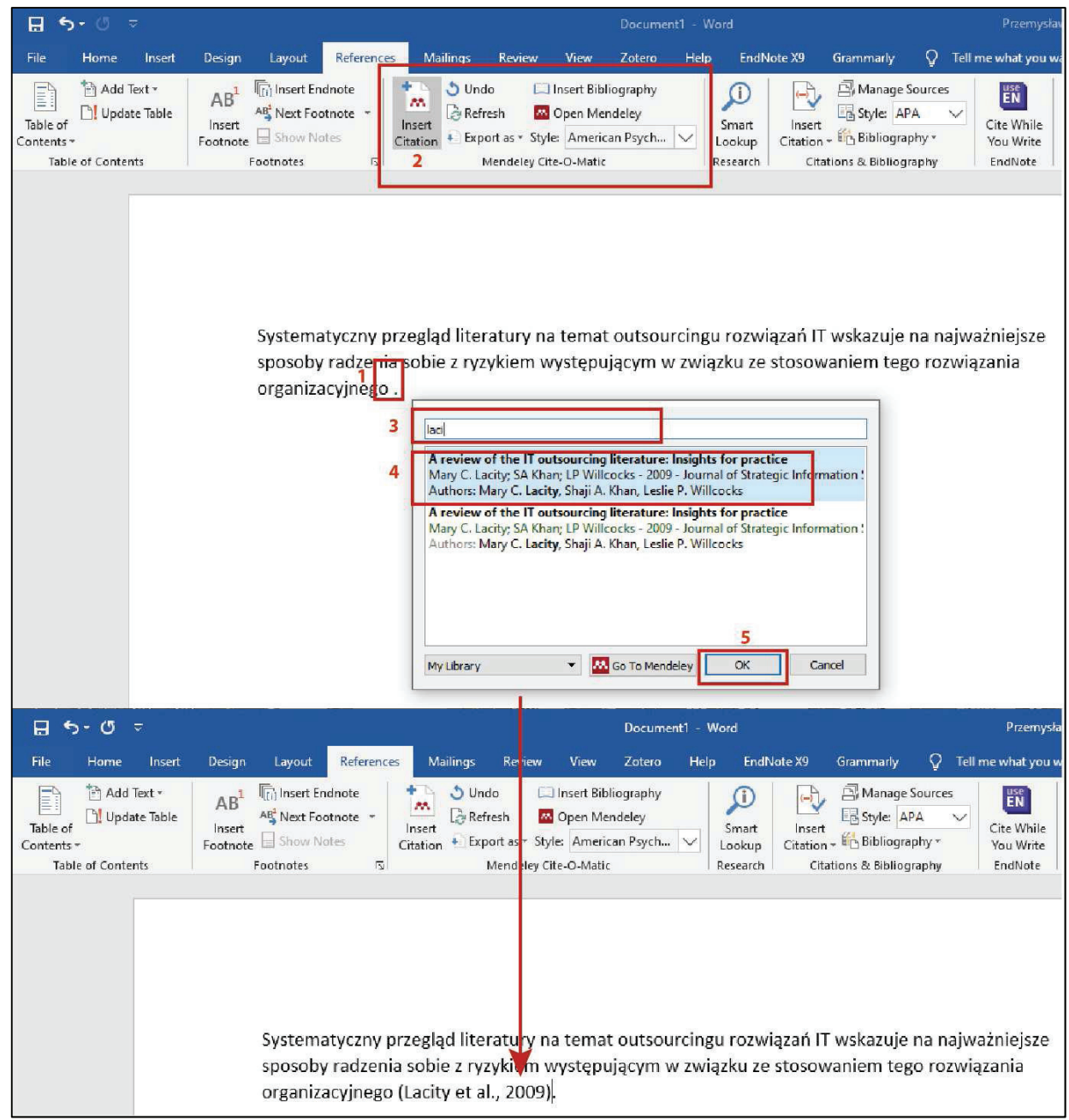

W celu wstawienia bibliografii (listy zacytowanej literatury) należy (rysunek 11): wybrać miejsce, w którym ma być wstawiona bibliografia (1), w okienku 
„Style” wybrać „American Psychological Association 7th edition”5 (2) i kliknąć „Insert Bibliography” (3).

\section{Rysunek 11. Dodawanie spisu wykorzystane literatury (bibliografii)}

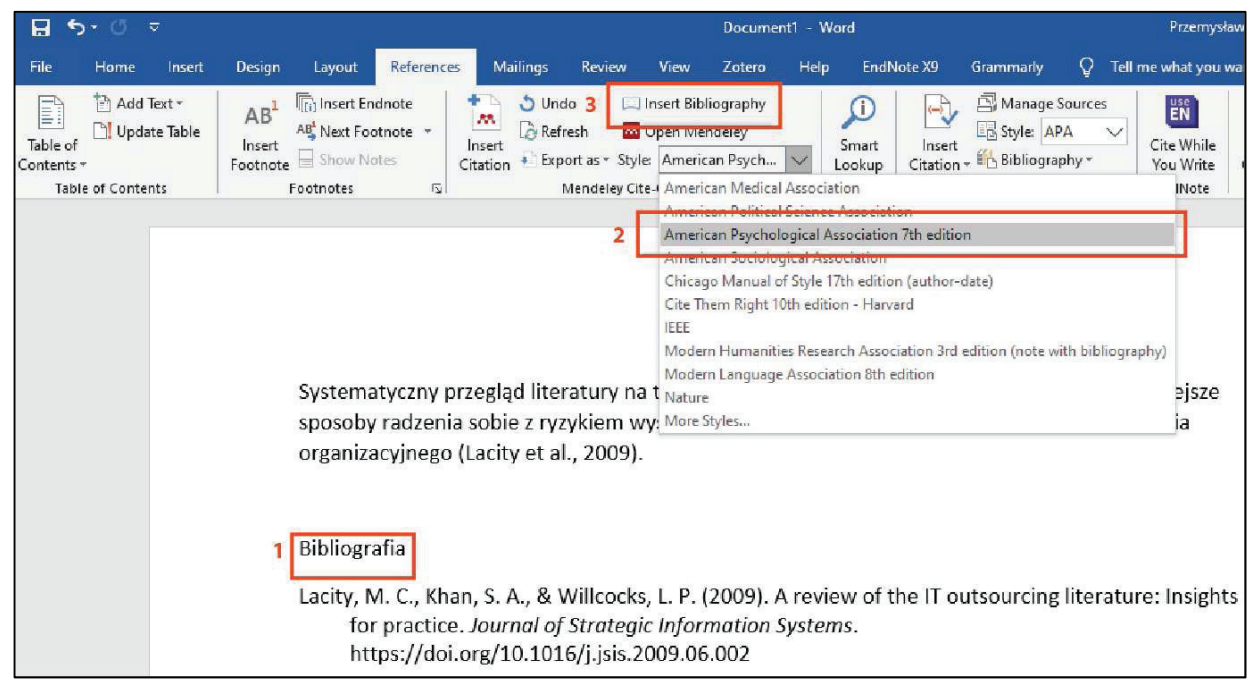

\subsection{Pozostałe narzędzia}

Do sporządzenia przeglądu literatury będziemy ponadto potrzebować:

- edytora tekstów, w którym sporządzimy raport z przeglądu literatury;

- arkusza kalkulacyjnego, który pozwoli na systematyczną ocenę poszczególnych badań;

- czytnika plików PDF (np. Adobe Reader), który jest niezbędny do otwierania i czytania poszczególnych tekstów;

- plugin Google Scholar Button do przeglądarki (Google Chrome, Firefox, Opera, MS Edge), który ułatwia wyszukiwanie pełnych tekstów artykułów oraz pobieranie danych bibliograficznych tekstów;

- warto też wyposażyć się w edytor tekstu dedykowany programistom, np. darmowy Notepad + +, który przyda się do formułowania zapytań do baz danych; tego rodzaju edytory nie wprowadzają żadnych zmian do tekstu (np. nie zamieniają cudzysłowów dolnych na górne), jak również ułatwiają śledzenie czy wszystkie nawiasy, które zostały otwarte zostały też zamknięte, co znacznie ułatwia tworzenie złożonych ciagu wyszukiwawczych.

5 Oczywiście możemy wybrać dowolny format bibliografii, jednak większość pism w naukach o zarządzaniu wymaga formatu APA. 
Ponadto, warto w edytorze tekstów (np. MS Word) zainstalować plugin do Mendeley (lub EndNote), który znacznie ułatwi pisanie końcowego raportu z przeglądu literatury. Plugin umożliwia wstawianie do tekstu odnośników literaturowych (referencji) i automatycznie tworzy bibliografię (p. 7.3.4). 


\section{Zalecane lektury}

Dla studentów, którzy chcą przygotować szybki systematyczny przegląd literatury:

Briner, R.B. i Walshe, N.D. (2014). From Passively Received Wisdom to Actively Constructed Knowledge: Teaching Systematic Review Skills As a Foundation of Evidence-Based Management. Academy of Management Learning \& Education, 13(3), 415-432. http://doi.org/10.5465/amle.2013.0222.

Dla naukowców, którzy chcą zapoznać się z metodą:

Tranfield, D., Denyer, D. i Smart, P. (2003). Towards a Methodology for Developing Evidence-Informed Management Knowledge by Means of Systematic Review. British Journal of Management, 14(3), 207-222. http://doi. org/10.1111/1467-8551.00375.

Siddaway, A.P., Wood, A.M. i Hedges, L.V. (2019). How to Do a Systematic Review: A Best Practice Guide for Conducting and Reporting Narrative Reviews, Meta-Analyses, and Meta-Syntheses. In S. T. Fiske (Ed.), Annual Review of Psychology, Vol 70 (vol. 70, ss. 747-770). Palo Alto: Annual Reviews.

Dla naukowców, którzy chcą poznać tajniki metody:

Cooper, H.M., Hedges, L.V. i Valentine, J.C. (red.). (2019). The handbook of research synthesis and meta-analysis. (3 wyd.). New York: Russell Sage Foundation. 


\section{Bibliografia}

Adams, R.J., Smart, P. i Huff, A. S. (2017). Shades of Grey: Guidelines for Working with the Grey Literature in Systematic Reviews for Management and Organizational Studies. International Journal of Management Reviews, 19(4), 432-454. http:// doi.org/10.1111/ijmr.12102.

Adler, N.J., Doktor, R. i Redding, S.G. (1986). From the Atlantic to the Pacific Century - Cross-Cultural Management Reviewed. Journal of Management, 12(2), 295-318. http://doi.org/10.1177/014920638601200210.

Ajzen, I. (1985). From Intentions to Actions: A Theory of Planned Behavior. W J. Kuhl i J. Beckmann (red.), Action Control: From Cognition to Behavior (ss. 11-39). Berlin, Heidelberg: Springer Berlin Heidelberg.

Ajzen, I. (1991). The Theory of Planned Behavior. Organizational Behavior \& Human Decision Processes, 50(2), 179.

Ames, E. i Reiter, S. (1961). Distributions of Correlation Coefficients in Economic Time Series. Journal of the American Statistical Association, 56(295), 637-656.

Amrhein, V., Gelman, A., Greenland, S. i McShane, B.B. (2019). Abandoning statistical significance is both sensible and practical. PeerJ Preprints, 7, e27657v27651. http:// doi.org/10.7287/peerj.preprints.27657v1.

Amrhein, V., Greenland, S. i McShane, B. (2019). Scientists rise up against statistical significance. Nature, 567, 305-307. http://doi.org/10.1038/d41586-019-00857-9.

Askew, K., Buckner, J.E., Taing, M.U., Ilie, A., Bauer, J.A. i Coovert, M.D. (2014). Explaining cyberloafing: The role of the theory of planned behavior. Computers in Human Behavior, 36, 510-519. http://doi.org/10.1016/j.chb.2014.04.006.

Bamberger, P. (2008). Beyond Contextualization: Using Context Theories to Narrow the Micro-Macro Gap in Management Research. Academy of Management Journal, 51(5), 839-846. http://doi.org/10.5465/AMJ.2008.34789630.

Barnes, C.M., Schaubroeck, J., Huth, M. i Ghumman, S. (2011). Lack of sleep and unethical conduct. Organizational Behavior and Human Decision Processes, 115(2), 169-180. http://doi.org/10.1016/j.obhdp.2011.01.009.

Baumeister, R.F. (2002). Ego Depletion and Self-Control Failure: An Energy Model of the Self's Executive Function. Self \& Identity, 1(2), 129-136. http://doi. org/10.1080/152988602317319302.

Baumeister, R.F., Bratslavsky, E., Muraven, M. i Tice, D.M. (1998). Ego depletion: Is the active self a limited resource? Journal of Personality and Social Psychology, 74(5), 1252-1265. http://doi.org/10.1037/0022-3514.74.5.1252. 
Bedeian, A.G., Taylor, S.G. i Miller, A.N. (2010). Management Science on the Credibility Bubble: Cardinal Sins and Various Misdemeanors. Academy of Management Learning \& Education, 9(1), 715-725. http://doi.org/10.5465/AMLE.2010.56659889.

Bem, D.J. (2011). Feeling the future: experimental evidence for anomalous retroactive influences on cognition and affect. Journal of Personality and Social Psychology, $100(3), 407$.

Bono, J.E. i McNamara, G. (2011). Publishing in AMJ-Part 2: Research Design. Academy of Management Journal, 54(4), 657-660. http://doi.org/10.5465/AMJ.2011.64869103.

Briner, R. i Denyer, D. (2012). Systematic Review and Evidence Synthesis as a Practice and Scholarship Tool. W D. M. Rousseau (red.), Handbook of evidence-based management: Companies, classrooms and research (ss. 112-129): Oxford University Press.

Briner, R.B. i Walshe, N.D. (2014). From Passively Received Wisdom to Actively Constructed Knowledge: Teaching Systematic Review Skills As a Foundation of Evidence-Based Management. Academy of Management Learning \& Education, 13(3), 415-432. http://doi.org/10.5465/amle.2013.0222.

Brutus, S., Aguinis, H. i Wassmer, U. (2013). Self-Reported Limitations and Future Directions in Scholarly Reports:Analysis and Recommendations. Journal of Management, 39(1), 48-75. http://doi.org/10.1177/0149206312455245.

Burleson, J. i Greenbaum, B.E. (2019). When Spheres Collide: A Refocused Research Framework for Personal Use of Technology at Work. Communications of the Association for Information Systems, 45, 411-432. http://doi.org/10.17705/1cais.04523.

Burrell, G. i Morgan, G. (1979). Sociological Paradigms and Organizational Analysis: Elements of the Sociology of Corporate Life. London: Heinemann.

Busse, C., Kach, A.P. i Wagner, S.M. (2017). Boundary Conditions: What They Are, How to Explore Them, Why We Need Them, and When to Consider Them. Organizational Research Methods, 20(4), 574-609. http://doi.org/10.1177/1094428116641191.

Campbell, D.T. i Stanley, J. (1963). Experimental and Quasi-Experimental Designs for Research (Vol. Dallas): Houghton Mifflin.

Cappelli, P. i Sherer, P.D. (1991). The missing role of context in OB: The need for a meso-level approach. W L. L. Cummings i B. M. Staw (red.), Research in Organizational Behavior (ss. 55-110). Greenwich, CT: JAI Press.

Chen, Y., Ramamurthy, K. i Wen, K.-W. (2012). Organizations' Information Security Policy Compliance: Stick or Carrot Approach? Journal of Management Information Systems, 29(3), 157-188. http://doi.org/10.2753/MIS0742-1222290305.

Chen, Y.R., Leung, K. i Chen, C.C. (2009). Bringing National Culture to the Table: Making a Difference with Cross-cultural Differences and Perspectives. Academy of Management Annals, 3(1), 217-249. http://doi.org/10.5465/19416520903047244.

Cheng, J.L.C. (1994). On the Concept of Universal Knowledge in Organizational Science - Implications for Cross-National Research. Management Science, 40(1), 162-168. http://doi.org/10.1287/mnsc.40.1.162.

Cheng, L., Li, W., Zhai, Q.G. i Smyth, R. (2014). Understanding personal use of the Internet at work: An integrated model of neutralization techniques and general deterrence theory. Computers in Human Behavior, 38, 220-228. http://doi.org/10.1016/j. chb.2014.05.043.

Cheng, L., Li, Y., Li, W., Holm, E. i Zhai, Q. (2013). Understanding the violation of IS security policy in organizations: An integrated model based on social control 
and deterrence theory. Computers \& Security, 39, 447-459. http://doi.org/10.1016/j. cose.2013.09.009.

Cohen, J. (1965). Some statistical issues in psychological research. Handbook of clinical psychology, 95-121.

Collaboration, O.S. (2015). Estimating the reproducibility of psychological science. Science, 349(6251), aac4716-4711-aac4716-4718. http://doi.org/10.1126/science.aac4716.

Combs, J., Crook, T. i Shook, C. (2005). The dimensionality of organizational performance and its implications for strategic management research. W D. Ketchen i D. Bergh (red.), Research Methodology in Strategy and Management (vol. 2, ss. 259-286). Bingley, UK: Emerald.

Cooper, H.M., Hedges, L.V. i Valentine, J.C. (red.). (2019). The Handbook of Research Synthesis and Meta-analysis. (3 wyd.). New York: Russell Sage Foundation.

D'Arcy, J. i Devaraj, S. (2012). Employee Misuse of Information Technology Resources: Testing a Contemporary Deterrence Model. Decision Sciences, 43(6), 1091-1124. http://doi.org/10.1111/j.1540-5915.2012.00383.x.

D’Arcy, J., Hovav, A. i Galletta, D. (2009). User Awareness of Security Countermeasures and Its Impact on Information Systems Misuse: A Deterrence Approach. Information Systems Research, 20(1), 79.

Dabić, M., Vlačić, B., Paul, J., Dana, L.-P., Sahasranamam, S. i Glinka, B. (2020). Immigrant entrepreneurship: A review and research agenda. Journal of Business Research, 113, 25-38. http://doi.org/10.1016/j.jbusres.2020.03.013.

Davis, M.S. (1971). That's interesting! Towards a phenomenology of sociology and a sociology of phenomenology. Philosophy of the Social Sciences, 1(4), 309-344.

DiMaggio, P.J. i Powell, W.W. (1983). The iron cage revisited: Institutional isomorphism and collective rationality in organizational fields. American Sociological Review, 48(2), 147-160. http://doi.org/10.2307/2095101.

Fainshmidt, S., Judge, W.Q., Aguilera, R.V. i Smith, A. (2018). Varieties of institutional systems: A contextual taxonomy of understudied countries. Journal of World Business, 53(3), 307-322. http://doi.org/10.1016/j.jwb.2016.05.003.

Fanelli, D. (2010). "Positive" Results Increase Down the Hierarchy of the Sciences. Plos One, 5(4), 1-10. http://doi.org/10.1371/journal.pone.0010068.

Franke, R.H. i Kaul, J.D. (1978). The Hawthorne Experiments: First Statistical Interpretation. American Sociological Review, (5), 623.

Fryxell, G.E. i Barton, S. L. (1990). Temporal and Contextual Change in the Measurement Structure of Financial Performance: Implications for Strategy Research. Journal of Management, 16(3), 553-569.

Garrett, R.K. i Danziger, J.N. (2008). Disaffection or expected outcomes: Understanding personal Internet use during work. Journal of Computer-Mediated Communication, 13(4), 937-958. http://doi.org/10.1111/j.1083-6101.2008.00425.x.

Greenberg, J. (1987). The College Sophomore as Guinea Pig: Setting the Record Straight. Academy of Management Review, 12(1), 157-159. http://doi.org/10.5465/ AMR.1987.4306516.

Henle, C.A. i Blanchard, A.L. (2008). The Interaction of Work Stressors and Organizational Sanctions on Cyberloafing. Journal of Managerial Issues, 20(3), 383-400.

Hensel, P. i Glinka, B. (2012). Teoria ugruntowana. W D. Jemielniak (red.), Badania jakościowe, tom 1: Podejścia i teorie. Warszawa: PWN. 
Hensel, P.G. (2017). Legitymizacja badań organizacji. Warszawa: PWN.

Hensel, P.G. (2018a). Institutionalized Publishing Practices as a Barrier to Participation in the Global Management Discourse. International Journal of Contemporary Management, 17(4).

Hensel, P.G. (2018b). Organizational Responses to Proto-Institutions. How the Semiedited and Unedited Accounts Clash. Journal of Management Inquiry, 27(2), 224-245. http://doi.org/10.1177/1056492616688086.

Hensel, P. G., i Kacprzak, A. (2020). Curbing cyberloafing: studying general and specific deterrence effects with field evidence. European Journal of Information Systems, http://doi.org/10.1080/0960085X.2020.1756701.

Herath, T. i Rao, H.R. (2009). Protection motivation and deterrence: a framework for security policy compliance in organisations. European Journal of Information Systems, 18(2), 106-125. http://doi.org/10.1057/ejis.2009.6.

Johns, G. (2017). Reflections on the 2016 Decade Award: Incorporating Context in Organizational Research. Academy of Management Review, 42(4), 577-595. http:// doi.org/10.5465/amr.2017.0044.

Johns, G. (2018). Advances in the Treatment of Context in Organizational Research. W F. Morgeson (red.), Annual Review of Organizational Psychology and Organizational Behavior, Vol 5 (vol. 5, ss. 21-46). Palo Alto: Annual Reviews.

Kerr, N.L. (1998). HARKing: Hypothesizing After the Results are Known. Personality \& Social Psychology Review, 2(3), 196-217.

Khansa, L., Barkhi, R., Ray, S. i Davis, Z. (2017). Cyberloafing in the workplace: mitigation tactics and their impact on individuals' behavior. Information Technology and Management. http://doi.org/10.1007/s10799-017-0280-1.

Khansa, L., Kuem, J., Siponen, M. i Kim, S.S. (2017). To Cyberloaf or Not to Cyberloaf: The Impact of the Announcement of Formal Organizational Controls. Journal of Management Information Systems, 34(1), 141-176. http://doi.org/10.1080/07421222. 2017.1297173.

Lewis, J. (2016). Using ATLAS.ti to Facilitate Data Analysis for a Systematic Review of Leadership Competencies in the Completion of a Doctoral Dissertation. SSRN eLibrary. http://doi.org/10.2139/ssrn.2850726.

Li, H., Zhang, J. i Sarathy, R. (2010). Understanding compliance with internet use policy from the perspective of rational choice theory. Decision Support Systems, 48(4), 635-645. http://doi.org/10.1016/j.dss.2009.12.005.

Lim, V.K.G. (2002). The IT Way of Loafing on the Job: Cyberloafing, Neutralizing and Organizational Justice. Journal of Organizational Behavior, 23(5), 675.

Mayo, E. (1933). The human problems of an industrial civilization. New York: Macmillan.

Mazzola, J.J. i Deuling, J.K. (2013). Forgetting What We Learned as Graduate Students: HARKing and Selective Outcome Reporting in I-O Journal Articles. Industrial \& Organizational Psychology, 6(3), 279-284.

McGrath, J.E. i Brinberg, D. (1983). External Validity and the Research Process: A Comment on the Calder/Lynch Dialogue. Journal of Consumer Research, 10(1), 115-124.

Mercado, B.K., Giordano, C. i Dilchert, S. (2017). A meta-analytic investigation of cyberloafing. Career Development International, 22(5), 546.

Miller, C.C., Washburn, N.T. i Glick, W.H. (2013). The myth of firm performance. Organization Science, 24(3), 948-964. http://doi.org/10.1287/orsc.1120.0762. 
Moher, D., Liberati, A., Tetzlaff, J., Altman, D.G. i PRISMA Group, T. (2009). Preferred Reporting Items for Systematic Reviews and Meta-Analyses: The PRISMA Statement. PLOS Medicine, 6(7), e1000097. http://doi.org/10.1371/journal.pmed.1000097.

Moody, G.D., Siponen, M. i Pahnila, S. (2018). Toward a Unified Model of Information Security Policy Compliance. MIS Quarterly, 42(1), 285-A222.

Morrissey, E.R. (1974). Sources of Error in the Coding of Questionnaire Data. Sociological Methods \& Research, 3(2), 209-232. http://doi.org/10.1177/004912417400300204.

O’Boyle, E.H., Banks, G.C. i Gonzalez-Mulé, E. (2017). The Chrysalis Effect: How Ugly Initial Results Metamorphosize Into Beautiful Articles. Journal of Management, 43(2), 376-399. http://doi.org/10.1177/0149206314527133.

Orlitzky, M. (2011). Institutionalized dualism: Statistical significance testing as myth and ceremony. Journal of Management Control, 22(1), 47-77.

Parsons, H.M. (1974). What Happened at Hawthorne? Science, 183(4128), 922-932. http://doi.org/10.1126/science.183.4128.922.

Paternoster, R. (1987). The deterrent effect of the perceived certainty and severity of punishment: A review of the evidence and issues. Justice Quarterly, 4(2), 173-217.

Pfeffer, J. i Sutton, R.I. (2006). Hard facts, dangerous half-truths, and total nonsense: profiting from evidence-based management. Boston, Mass.: Harvard Business School Press.

Pinker, S. (2003). The blank slate: the modern denial of human nature. New York: Penguin Books.

Plomin, R. (2019). Blueprint: How DNA Makes Us Who We Are. Cambridge, MA: The MIT Press.

Polito, A. (1997). Cyberloafing can be curbed. Workforce, 76(3), 18-18.

Richard, P.J., Devinney, T.M., Yip, G.S. i Johnson, G. (2009). Measuring organizational performance: Towards methodological best practice. Journal of Management, 35(3), 718-804. http://doi.org/10.1177/0149206308330560.

Roethlisberger, F.J. i Dickson, W.J. (1941). Management and the Worker. Cambridge: Cambridge University Press.

Rousseau, D.M. (2012a). Envisioning Evidence-Based Management. W D. M. Rousseau (red.), The Oxford handbook of evidence-based management (ss. 3-24). Oxford: Oxford University Press.

Rousseau, D.M. (red.) (2012b). The Oxford handbook of evidence-based management. Oxford: Oxford University Press.

Rousseau, D.M. i Fried, Y. (2001). Location, location, location: contextualizing organizational research. Journal of Organizational Behavior, 22, 1-13.

Schwab, A., Abrahamson, E., Starbuck, W.H. i Fidler, F. (2011). Researchers should make thoughtful assessments instead of null-hypothesis significance tests. Organization Science, 22(4), 1105-1120. http://doi.org/10.1287/orsc.1100.0557.

Shadish, W.R., Campbell, D.T. i Cook, T.D. (2001). Experimental and quasi-experimental designs for generalized causal inference. Boston: Houghton Mifflin.

Siddaway, A.P., Wood, A.M. i Hedges, L. V. (2019). How to Do a Systematic Review: A Best Practice Guide for Conducting and Reporting Narrative Reviews, MetaAnalyses, and Meta-Syntheses. W S. T. Fiske (red.), Annual Review of Psychology, Vol 70 (vol. 70, ss. 747-770). Palo Alto: Annual Reviews.

Simmons, J.P., Nelson, L.D. i Simonsohn, U. (2011). False-Positive Psychology: Undisclosed Flexibility in Data Collection and Analysis Allows Present- 
ing Anything as Significant. Psychological Science, 22(11), 1359-1366. http://doi. org/10.1177/0956797611417632.

Snow, C.E. (1927). Research on industrial illumination: A discussion of the relation of illumination intensity to productive efficiency. Tech Engineering News (listopad).

Stanley, T.D., Carter, E.C. i Doucouliagos, H. (2018). What Meta-Analyses Reveal About the Replicability of Psychological Research. Psychological Bulletin, 144(12), 1325-1346. http://doi.org/10.1037/bul0000169.

Steers, R.M. (1975). Problems in the Measurement of Organizational Effectiveness. Administrative Science Quarterly, 20(4), 546-568.

Sterling, T.D. (1959). Publication Decisions and their Possible Effects on Inferences Drawn from Tests of Significance-or Vice Versa. Journal of the American Statistical Association, 54(285), 30-34. http://doi.org/10.1080/01621459.1959.10501497.

Tourish, D., i Craig, R. (2020). Research Misconduct in Business and Management Studies: Causes, Consequences, and Possible Remedies. Journal of Management Inquiry, 29(2), 174-187. http://doi.org/10.1177/1056492618792621.

Tranfield, D., Denyer, D. i Smart, P. (2003). Towards a Methodology for Developing Evidence-Informed Management Knowledge by Means of Systematic Review. British Journal of Management, 14(3), 207-222. http://doi.org/10.1111/1467-8551.00375.

Valentine, J.C. (2019). Incorporating Judgments About Study Quality into Research Syntheses. W H. Cooper, L. V. Hedges i J. C. Valentine (red.), The Handbook of Research Synthesis and Meta-analysis (3 wyd., ss. 129-140). New York: Russell Sage Foundation.

Venkatesh, V., Morris, M.G., Davis, G.B. i Davis, F.D. (2003). User Acceptance of Information Technology: Toward a Unified View. MIS Quarterly, 27(3), 425-478. http:// doi.org/10.2307/30036540.

Whitehead, T.N. (1938). The industrial worker. Cambridge: Harvard University Press.

Zhu, H. i Chung, C.-N. (2014). Portfolios of Political Ties and Business Group Strategy in Emerging Economies: Evidence from Taiwan. Administrative Science Quarterly, 59(4), 599-638. http://doi.org/10.1177/0001839214545277. 

$\because \cdots$ 